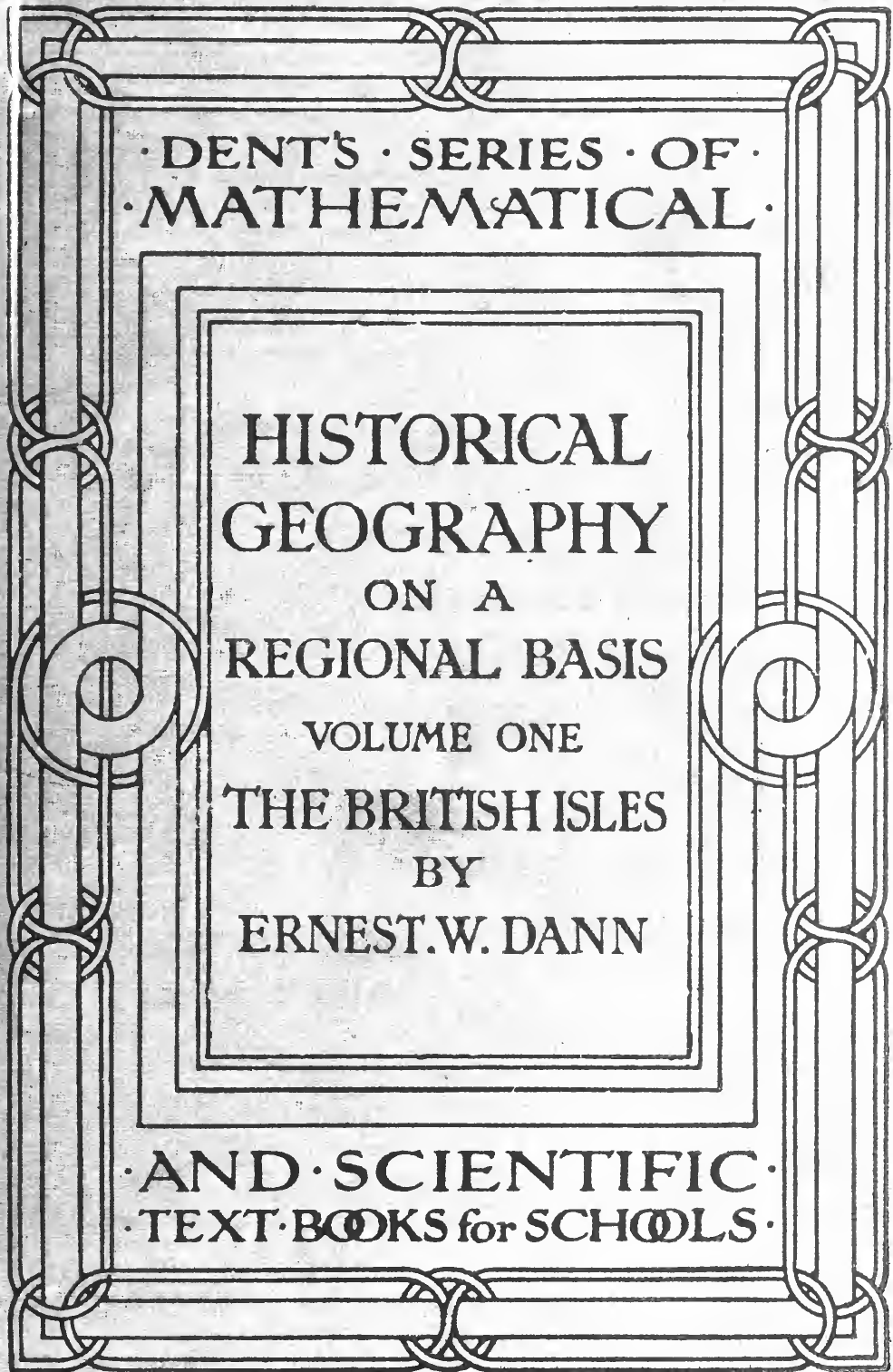


$\mid \begin{aligned} & 1 \\ & y \\ & y\end{aligned}$

$$
\text { . }
$$$$
\text { (1) }
$$

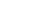


Digitized by the Internet Archive in 2007 with funding from

Microsoft Corporation. 
DENT'S MATHEMATICAL \& SCIENTIFIC TEXT BOOKS FOR SCHOOLS

$$
\text { EDITED BY }
$$

W. J. GREENSTREET, M.A., F.R.A.S.

HISTORICAL GEOGRAPHY

ON A REGIONAL BASIS 
All rights reserved 
HMod

Dis8h

\section{HISTORICAL GEOGRAPHY \\ ON A REGIONAL BASIS}

BY

ERNEST W. DANN, B.A. (Oxon.)

FELLOW OF THE ROYAL GEOGRAPHICAL SOCIETY ;

ASSISTANT MASTER, REIGATE GRAMMAR SCHOOL.

THE BRITISH ISLES

WITH SIX MAPS

VOL. I.

WITH THE PUBLISHERS
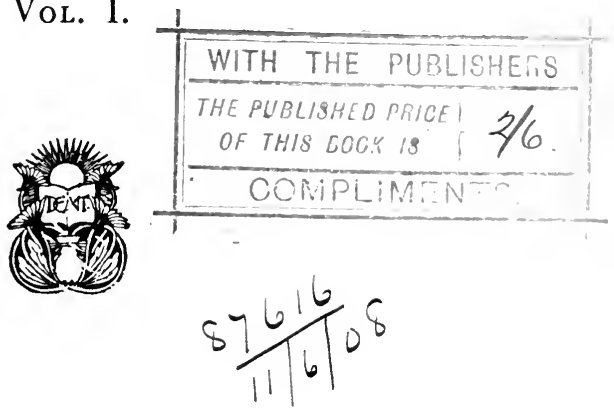

LONDON

J. M. DENT \& CO.

$29 \& 30$ BEDFORD STREET, W.C.

1908 
Richard Clay \& Sons, Limited, BREAD STREET HILL, E.C., AND

D BUNGAY, SUFFOLK.

209

D35

$v, l$ 


\section{PREFACE}

This little volume has been written, at the invitation of the Editor, to give students a more definite idea of the inter-relation of Geography and History than they can possibly gain from the passing allusions in books entirely devoted to the one or the other subject. Of the importance of Historical Geography there can be no doubt: but there is a great deal of confusion of terms. It is often forgotten that Geography is the substantive and Historical the adjective, and it is most important to give the science its proper physical basis. Moreover, the study of it should be based upon reason and not upon memory. Kaleidoscopic political changes at rapid intervals do not require a high order of intelligence to acquire, and are merely interesting; the study of man on the earth is a far deeper matter. Moreover, the basis of treatises upon Historical Geography hitherto has been in the main chronological. That is well for the History; but it gives no sort of clue to the real physical causes of things, and so loses its value as a mental discipline. My aim has been to preserve chronology in so far as it does not interfere with 
regional treatment. This has been easy enough in the case of the British Isles. A country so small can have but few main highways. Practically the whole thing centres on London. To London from the Continent; from London to Ireland and Wales, and to Scotland by two routes; that sums up most of our "dynamical" History. The "statical" is a matter of climate. In the case of Europe the subject has to be greatly modified in scope, and, while narrative History has to be largely eliminated, regional treatment is more thoroughly employed.

I have quoted authorities pretty freely. The main difficulty is finding enough to use successfully in any particular branch. Historians are often too much bound down by other exigencies to present the details we need to give us a full understanding of many important topographical matters, and most Historical Atlases stultify their maps, either by leaving out mountains altogether, or by representing their often wide areas as hairy caterpillars. Any map will do, it is assumed, if it shows approximately where a place is. I would urge all teachers of History to insist on using a good physical wall-map constantly. Kiepert, or Habenicht, or Philip or E. Stanford, all can supply the need at a reasonable figure, and Philip's and Bartholomew's cheap atlases can be successfully used, if supplemented by good teaching, by any class. Boys and girls, as a not inconsiderable experience has taught 
me, take fifty per cent. more interest in History when it is intelligently treated in the light of Geography, or vice versa $\hat{a}$, than they ever did before.

For reading the whole of the proofs I am indebted to Mr. A. Lund Newell, Secretary to the Reigate Education Committee. For the rest, I should like to declare myself one of the many who have profited by the kindly encouragement of Mr. Herbertson at Oxford, and by the inspiring lectures of his predecessor as Reader of Geography there, Mr. H. J. Mackinder.

E. W. D.

Claremont,

Chart Lane,

Reigate; Nov. $190 \%$. 



\section{CONTENTS OF VOL. I}

CHAP.

PAGE

I. INTRODUCTORY

II. PHYSICAL FEATURES AND HISTORY • • 12

III. REGIONAL GEOGRAPHY OF BRITAIN . . . 28

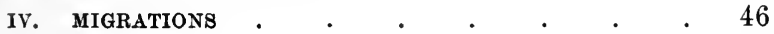

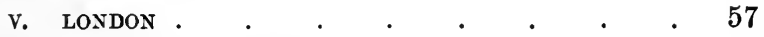

VI. WALES AND ENGLAND . . . . . . . 71

VII. SCOTLAND AND ENGLAND . . . . . 88

VIII. IRELAND AND ENGLAND • • • • . $\quad$ • 112

IX. POLITICAL Divisions . . . . . $\quad$. 124

X. SEA-POWER AND HISTORY . . . . $\quad$. 137

XI. HISTORIC TOWNS . . . . . . 155

XII. GREATER BRITAIN . . . . . . . 170 


\section{LIST OF PLATES}

I. MAJOR NATURAL REGIONS • • . faring page 26

II. BRITAIN AND ADJACENT LANDS - • , . 56

III. LONDON AND ITS APPROACHES . . $\quad,, \quad 68$

IV. WALES AND THE MIDLAND PLAIN • • " 86

v. EAST AND WEST COAST ROUTES TO SCOTLAND , 110

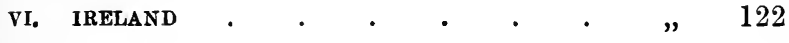





\section{CHAPTER I}

INTRODUCTORY

1. Scope of Geography.-There are many definitions of the term Geography, and it is not our purpose here to argue out the precise limits of the subject. We must, however, try to find out, at any rate, what it is not, so as to gain a starting-point in our brief study in this volume of one phase of it. Dr. H. R. Mill says : "Geography is the exact and organized knowledge of the distribution of phenomena on the surface of the earth, culminating in the explanation of the interaction of man with his terrestrial environment."

The core of that definition is the word distribution. Suppose we are considering rainfall. If we were learning what is generally called Physiography, and if we were treating of rainfall, we should explain why rain falls. In Geography we learn both why and where. Then we go on to consider how rainfall affects the various regions of the world, what vegetation it helps to produce, and how man adapts himself to its abundance or scarcity.

2. Historical Geography.-It will be seen, then, that we must always begin from the physical. If we merely 
say, for instance, that Liverpool is on the Mersey and imports cotton, we have learned a fact and no more. If, however, we study the position of Liverpool, the structure of the estuary on which it stands, the Midland Gate, and the facilities for the growth, on a coal-field, of many large towns inland, with easy communication seawards, as well as the sources of cotton supply, we have learned our main fact in a scientific way and also opened our eyes to similar interactions of cause in other places.

When we are dealing with History, it is not sufficient to know where events took place. We must try to find out why there. Now, it is useless to suppose that we can always do so; but it is not too much to say that History and Geography are inseparable, and that all leading actions of men have their first cause in the nature of the lands in which they live. No one expects Eskimos, or Red Indians, or Hindus ever to become world-conquerors, explorers or colonists. Their climate, their distance from good harbours, the structure of their lands all forbid such development. When, therefore, we learn that this nation rose, that that nation fell, that this city has grown while that one has not, that migrations, and campaigns, and battles have occurred in certain places, we must try to find out how far these events have been moulded by geographical position. Half the History we learn can never be fully understood or appreciated if we do not carefully consider its 
geographical side. Historical Geography, properly so called, is the "explanation of the interaction of man with his terrestrial environment," that is, the explanation of the way in which man's surroundings have moulded his actions. Therefore, when we study History, we should not occasionally look out some tiny village, marked with crossed swords on a map which only shows rivers, towns and coastline; we should constantly have before us a physical map of the region we are studying.

3. Physical features and History.-It is easy to illustrate how physical features affect History. Low land, especially at the mouth of some navigable stream, may be expected to serve as the place of entry into a country for hostile peoples. We remember how in our own country the Thames Estuary, the Wash, the Humber and Southampton Water gave entry to Saxon and Dane; how the Dublin lowland made the heart of Ireland easy of access to Strongbow, to Essex, to Cromwell; how Lisbon gave a base to the English in their struggle against Napoleon's marshals; how the Guadalquivir gave the Moors an entry into Spain, and how the possession of the St. Lawrence gave us Canada. To realize the force of these illustrations you must look at the physical, or, as it is sometimes called, the orographical ${ }^{1}$ map of the regions mentioned.

1 Greek, oros, a mountain. We shall use the term "height map" to mean "orcgraphical map," i.e. a map which depicts mountains, 
This rule concerning lowland and river mouths does not by any means always hold good. The River Amazon, vast flood that it is, with an enormous basin stretching for nearly 2000 miles back to the Andes before it even reaches an elevation of 600 feet, is no easy highway into South America, although the height map would tell us that it is. The reason is to be found in the dense tropical rain-forest which occupies the whole region. The Niger mouth never led explorers in the direction of Timbuktu: a physical map does not show its ill-defined delta, a maze of mangrove swamp. Hudson's Bay is not the classic waterway into Canada. It is too often frost-bound. Latitude plays its part. Harbour facilities are profoundly important. The fact of facing, or not facing other important lands is always to be considered. But even here the chief feature is land structure.

4. Man and his Surroundings. - We must not, however, forget that, when we are dealing with man, we are considering a very variable and difficult phenomenon. Some peoples are the absolute slave of their surroundings ; some often rise superior to them. The Turks, for instance, have allowed Bagdad, in former days one of the world's great cities, to sink into partial decay owing to the silting up of the Tigris. Contrast this with Glasgow. The Clyde was fordable at this point within the memory of living man. Now the river has been dredged, and the largest ocean steamers can sail up to the wharves of this great port and discharge their loads: 
in what has become the second city of the United Kingdom.

Sometimes man conquers obstacles which have seemed insuperable. A hundred years ago no one would have thought it possible to traverse the Alps at a high speed in a few hours in comfort, nay, even in luxury; but at the present day we have three separate railway routes through this range-three successive and signal triumphs of engineering skill. Think, too, of Hannibal's marvellous attack upon Rome in the Second Punic War. Unable to travel by sea-for Rome had command of the Mediterranean-he invaded Spain, crossed the Rhone, traversed the Alps with a surviving force of 20,000 foot and 2000 horse; after a few days he chastised the hostile barbarians, took from them their city of Turin, and then faced the power of Rome, with its army of 170,000 men. This is a military feat without parallel in history, to win one's way to an enemy's capital through a half-subdued country (Spain), to take an African army, and several elephants, across a snow-covered range, and to maintain the struggle for years against almost overwhelming odds. The British development, quite recently, of the port of Durban, and the establishment, in one of the most unpromising spots on the earth, of the port of Aden, for strategic purposes, are other instances of the way in which a progressive people defies nature to baffle its growth.

5. "Freedom loves the hills."-It is well known that 
hill peoples are almost invariably lovers of freedom. The Swiss, the Afghans, the Scots, the Welsh have all made history by their grand struggles for independence. The question of physical surroundings goes much farther than one would at first suppose. Take for an instance Albania. The Shar range permits no passage of loaded animals: the hills slope towards swampy ground or an inhospitable shore: and torrential streams, fed by a copious rainfall, flow in deep troughs througli hills of very steep incline. The consequence is the scparation of clan from clan, absence of common sentiment or authority, a glorification of fighting, a devolution of all hard work upon women, blood-feuds, dislike of town life, and all the evil passions bred by these habits of existence. Yet thesc same people, if found in other parts of this region, in Constantinople or the Lerant, become, in their changed conditions, comparatively harmless and even ornanents to society. Farther south, in a flatter country, these dreaded Ghegs give place to the more amenable Toskhs, flocks and herds are kept, there is no blood-feud, strangers are admitted, some attention is paid to the soil, and the use of weapons is no longer the be-all and end-all of existence. ${ }^{1}$ Indeed, in small areas we can see very wide differenccs in people who have always lived on the land. Most people can see a wide difference between what Northerners call the "sturdy independence" (while South-

1 The Nearer Last, by D. G. Hogarth, pp. 229 sqq. 
erners use a less complimentary term) of your Yorkshire or Lancashire man, and the milder and more considerate manners of those who dwell in the Thames Valley or the Eastern counties. And how the cultured and artistic Athenians of old poured scorn and contempt upon the farmer Thebans, "Bœotian pigs," as they named them!

6. Sea-power and History.-No Englishman needs to be reminded of the importance of sea-power. Our insular position, added to the magnificent way in which the nation has taken advantage of it, is the root cause of the very existence of what is assuredly the most amazing world-power that history has ever seen. A hundred years ago Napoleon had his great camp of 300,000 men ready at Boulogne: but he was never able to start upon even so short a journey as that to England. According to an account published at the time, two tides, i.e. nearly a whole day under the circumstances, were necessary to get the whole flotilla to sea: and a fleet far feebler than ours could have very scriously delayed operations and given full notice of the Emperor's approach. Even if the invasion had been successful, it is difficult to see how the French army could have won its way back to Europe. Again, one of the dearest aims of the German Kaiser at the present time is to create a fleet large enough to claim command of the seas. Germany feels that, however invincible her army may be, she is ill-fitted for a great 
conflict if one of her two arms is weak. A large army is absolutely paralyzed for aggressive work if not supported from without by a powerful fleet. Russia's disaster in the Korean Straits put an end to her chances of maintaining successful conflict with Japan. The Trans-Siberian or any other railway cannot hope to compete with the sea as a means of transporting large bodies of men and enormous quantities of stores; and Japan was at perfect liberty, having once gained command of the sea, to land as many men and guns as she pleased, and wherever she thought fit.

7. Geology and History.-Even geology, the science which deals with the materials and formation of the earth's crust, can over and over again be shown to have a distinct bearing upon history. Geology and geography overlap so pronouncedly in some departments that it is necessary to point out here that, if we use the former word in its full sense, this science will be found to have played a very important part in quite half our history. If, however, we limit our meaning to rock structure, we can even then, in many cases, find remarkably instructive features. Sir Archibald Geikie ${ }^{1}$ has illustrated this wonderfully in the case of Scotland, and Professor George Adam Smith ${ }^{2}$ in the case of Palestine. But it is only in part that geological structure affects human conditions. Orographical features are the

1 Scenery of Scotland, chapter xix.

${ }^{2}$ Historical Geography of the Holy Land. 
features to study in this connection. The Alps, whether they be crystalline or calcareous, Archæan or Miocene, are everywhere a barrier to communication. But it is equally true that many parts of the Nearer East would be more habitable and less arid if the streams carved their beds in sandstones or clays instead of permeable limestones. The Highlands of Scotland are incapable of supporting a large industrial or agricultural population, not merely because they are Highlands (for so are the fertile parts of Switzerland), but because of the materials of which they are composed. "Not a tree or a bush casts a shadow over these wastes of barren rock. . . . Grey, rugged and verdureless, they look as if they had but recently been thrust up from beneath the waves, and as if the kindly hand of Nature had not yet had time to clothe them with her livery of green. ... The whole landscape is one wide expanse of smoothed and rounded bosses and ridges of bare rock, which, uniting and then separating, enclose innumerable little tarns." The history of such regions as these is a history of clans and forays. Geological structure, then, can be often shown to play its part; but it is by no means our purpose to go beyond the domains of pure geography.

8. Summary.-It may well be imagined that, if we are to study Historical Geography upon the lines laid down, our task is a great one. The term has usually been applied to a casual study of the political control 
of certain regions at certain times. Voluminous works and monumental atlases have been compiled to illustrate this kind of thing, and they are immeasurably useful : but the mastering of them is merely a matter of memory. Historical Geography, as we understand it, is no mere memory work : it is thoroughly scientific, and it is, as far as literature is concerned, in an embryo stage. It must be understood that to take every region of the world and to argue out its history in the light of its geography is a stupendous undertaking: to show how similar events have recurred in similar places all down the ages postulates a truly colossal knowledge. Something, however, can be done in this direction, and as inexpensive books dealing with the history of, say, Hungary, Servia, Poland, or Afghanistan are certain to appear in the natural order of things, no student, however humble, need despair of learning the true Historical Geography of any region he may care to study. The boundaries of Prussia at different times in the world's history, or those of France, have depended as much upon accidents, such as the existence of great ministers or incapable generals, as upon questions of mountain and valley and plain; but the battles of Blenheim and Hohenlinden and the surrender at Ulm, or the fights at Kolin, Prague, the White Mountain, Lobositz and Königgrätz point to the fact of man's activities being directed into the same channel over and over again, and demand an answer to the question, Why there? 
This work is only a small two-volume manual. Its object is not to satisfy, but to stimulate. It does not profess to be anything but a skeleton of its subject. Almost any student will be able to supplement it at some point. But the whole field which it opens is vast. Learn the geography of your own district. Learn its history at the same time, and see how far the latter is dependent upon the former. In this volume we hope to treat of the British Isles: in the second, Europe is to be the subject. If we can cause the student to think for himself, our end is gained. We wish to be suggestive, and make no attempt to be exhaustive. The main idea to be borne in mind is man in his environment. This may mean Anthropology, or Commerce, or even Religion (for religious creeds have very definite geographical distributions). We confine ourselves to History. 


\section{CHAPTER II \\ PHYSICAL FEATURES AND HISTORY}

1. Evolution:-In these days, when the great doctrine of Evolution is a guiding principle in science, it is natural to attribute the habits, nay; even the dispositions of men to their "environment." It is possible to go very far in showing how different species of the same genera of living creature owe their peculiarities to the exigencies of their separate and several surroundings: The larger cats are good instances of this. In the jungles of Bengal the tiger is found, his black stripes on yellow fur affording him concealment which would be denied him if he were a darker animal. The lion inhabits drier lands in Africa, Arabia and Persia, and his uniform tawny colour, against his background, is of great use to him. The jaguar, a creature sometimes almost black in hue, haunts the dusky shades of the South American rain-forest. Plants, too, even to persons of most ordinary knowledge, show the same characteristics. In the Mediterranean region, for instance, the plants are specialized to resist droughts; they have thick, fleshy leaves and long roots, and are mostly evergreens. In the tundra mosses and lichens grow; 
and on the steppes the peculiar weather conditions make it impossible for trees to thrive, and bulbous plants and grasses flourish. Man is also subject to the same general laws, but in a less degree.

\section{Man classified according to geographical conditions.} -Of all the various phenomena on which man's characteristics are dependent, the chief is climate. This will be found to be all-inclusive, as climate depends upon rainfall, upon temperature, upon latitude and upon altitude. It will be useful to give a brief sketch of the varying conditions under which man pursues his daily vocations in different parts of the world. To preface this, it will be necessary to see how the world can be divided into suitable regions as a basis of our investigation. This has been done by Mr. Herbertson. In the March, 1905, number of the Geographical Journal appeared a paper by him upon the Major Natural Regions. We reproduce his map, by his kind permission, and with his own corrections, and use his divisions as our standard. (See Plate I.) It is based mainly on climate. "Only when minor forms are taken into consideration does configuration become the all-important factor." ${ }^{1}$ The explanation of the divisions is as follows:-

3. Areas marked 1 are Polar.-1 1 represents lowlands. This type of country is known as Tundra. In lands of this description the temperature in summer seldom

${ }^{1}$ Geographical Journal, xxv. 3, p. 309. 
exceeds $50^{\circ}$ : in winter it is almost incredibly cold. Dwarfed woods in the more southerly parts, mosses and lichens only in others constitute the sole vegetation. The rivers abound in salmon, and the reindeer is the characteristic land-animal. The divarf birch, about three feet high, and cranberries and kindred bushes are sometimes mingled. Swampy ground bears reeds and downy willows. Man exists upon fish and reindeer flesh, doing a not inconsiderable trade in the summer in furs. This region will be seen to extend right across the mainland of North America and Eurasia, and to include most of Labrador, beginning in the Old World in Lapland and extending eastwards to Kamchatka. Greenland is of another type, and belongs to

1b. This is the ice-cap type. For obvious reasons, not. much is known of countries of this description: they do not invite the traveller to tarry. Great glaciers descend from the heights to the sea and break off into huge icebergs, and these have a marked effect upon navigation in the North Atlantic. The ice is of immense thickness, and is penetrated in places by lofty mountains.

4. Areas marked 2 are cool temperate regions.-In the Polar lands we have areas which can never, in the natural order of things, have much bearing upon man's activities. Here, however, we come to lands of the lighest importance.

$2 \alpha$ represents the Western margin of continents in 
fairly high latitudes. The fortieth parallel roughly represents the boundary on the Equatorial side, and Western Europe is the chief area. It is only necessary to say that the French, the English, the Dutch and the Germans belong to this country to realize how important it is. The air is neither too hot nor too cold. It is very rarely the case that man cannot go about his business any day in the year. Ports are perpetually open: harbours happen to be numerous, and where they are deficient the energy of man makes good the defect. The canals and polders of Holland, and the immense mark made upon the pages of history and economics by the Western European nations generally, speak eloquently of man, highly developed through having no serious climatic obstacles to surmount, taking full advantage of his opportunities, and rising superior to difficulties when they face him. Rainfall is adequate at all seasons and abundant in some, vegetation is of the forest or forest-clearing type: soils are either good naturally or are made so by the ingenuity of scientific man, and in Europe mountains are no barrier to communication. In the case of the New World, the structure of the land makes a great difference to human geography. Here the folded ranges are parallel to the coast, and hinder communication. In Europe they have a West-East trend, and do not reach the coast at all in the region under notice.

$2 b$ represents the Eastern margin of continents, and 
Quebec is given as the characteristic area. No part of Europe is included, but the Great Lakes and the New England seaboard, and the nearer portion of our Canadian realm are contained in it. Rainfall is very moderate, nowhere exceeding forty inches per annum, structure is on the whole favourable to commercial intercourse, but temperature is unpleasantly extreme. On the other hand, $2 b$ has been peopled by the surplus population of $2 \alpha$ and their descendants, and, now that the lands are becoming more highly developed, is playing a supreme part in present history. In the case of Asia, climatic conditions are more extreme than in America, and land-structure is all against man.

$2 c$ represents the interior lowlands. Two great areas belong to this type: the first is the Canadian portion (roughly speaking) of the great central lowland of America, excluding the tundra; and the second is the enormous stretch of level land, only broken by the Urals, which reaches from, say, the Oder and the political boundary of Sweden to the River Lena. There is a remarkable uniformity of physical conditions. The Arctic regions are not separated from the $2 c$ lands by any heights, and, accordingly, the northern blasts reach as far south as the Black - Sea without any mitigation of their intense bitterness. Hence the January isotherm of $32^{\circ} \mathrm{F}$. enters Scandinavia in longi-. tude $15^{\circ} \mathrm{E}$, near the Arctic Circle, descends, via the Carpathians, to the mouth of the Danube, and then 
runs almost along the fortieth parallel to the Pacific. That is to say, directly conditions become continental, winter becomes rigorous. $2 \alpha$ lands are comfortably cool when it is almost impossible to keep out the deadly chill twenty-five degrees further South in 2 . The summer is uniformly hot and dry, becoming slightly hotter and very much drier the farther we go East. As far as human geography is concerned, it is only necessary here to say that Germany and Russia largely belong to this region. Huge crops of wheat are raised on the edges of the steppes, and there is a tremendous forest belt, coniferous, mixed and deciduous, of the highest value. These lands are interrupted on the scaward side by

$2 d$. These are interior mountain areas, the Altai in Eurasia, and the Rockies in America. It is not too much to say that if $2 c$ had reached to the Pacific, there would have been profound modifications in the history of the world. Russia's Eastern expansion would have been uninterrupted at a time when neither England nor Japan was in the position to circumscribe it. In the case of Canada the area of cultivation is seriously curtailed by the presence of high land, but man has founded great settlements on the West.

5. Areas marked 3 are warm temperate regions. $-3 a$ represents Western margins with winter rains. The Mediterranean in Europe, California in N. America, Chile in S. America, the Cape of Good Hope, the south- 
eastern and south-western corners of Australia, and the North Island of New Zealand constitute the main examples. Dry summers prevail, and droughts are not infrequent. In winter there is enough moisture to perpetuate the existence of plants which can live for a long time, owing to their lengthy roots, without wet and in a scorching sun. Wheat, too, is a characteristic crop. Adequate rain to start the green shoots, and a hot sun to ripen the grain are the chief requirements, and a glance at a wheat map of the world ${ }^{1}$ shows that that commodity is marked in all the above-mentioned lands. Generally speaking, colonists have peopled the $3 a$ region, the European area being a most important exception. Here the height map shows features which greatly complicate one's study, but it is worth while to notice that the men who have for many centuries lived in Southern Europe and the Atlas lands have shown a steady deterioration. This is generally ascribed to the enervating climate, which demands the luxurious midday siesta, and to the obscurantist influences of nonprogressive religions. Certain it is that the Spaniard of to-day is far behind his ancestors of the seventeenth century, and the twentieth century Italian is far behind in the race which he so nobly led in the days of the new mariner's compass. Still more is the modern hybrid Greek a mere shadow of the classic citizen of Athens, Sparta or Thebes. But these questions

1 e.g. pp. 62-3 of Atlas of the World's Commerce. Newnes. 
will be found more fully discussed in our Second Volume.

$3 b$ represents Eastern margins with summer rains. China, New South Wales, Natal and the Appalachian region of North America are herein comprised, and it may immediately be said that in no case are conditions against human activity. Unpleasantly cold and unpleasantly hot weather do not as a rule seem to affect the activities of human beings. Buffalo, New Orleans, Pittsburg, Washington, Peking, Sydney, are proofs of the importance of the region, the home of some of the great races of modern times.

$3 c$ regions are the interior lowlands, such as part of the Mississippi basin, the Pampas of South America, and Turan, the Ural-Caspian lands, which the height map reveals as a huge depression. These are steppe lands. Steppe varies considerably. The winter-time is unpropitious for all creatures, and often insupportable. Summers are arid, but on the whole bearable, and spring-time is a beautiful season. The main question, however, is one of soil. The Red River (of the north) region is world-famous as a wheat land, and the Argentine is being rapidly developed both for arable and pasture. On the other hand, much of Turan is ruined by excessive salinity. The inhabitants are essentially nomadic: they keep flocks and herds, and have to go where feed is to be found. In themselves, they have never made history; but their lands, owing 
to structure and geographical position, have ever been on the highway from West to East or East to West, and loom large in the annals of the past. For similar reasons, this is even more so in the case of the adjoining Asiatic part of

3c. These regions are inland plateaus. Patagonia, which has never, owing to its remote position, played a great part on the world's stage; Mongolia, which has suffered from like causes as well as from the gradual drying up of the land, and Iran, the highland between the Levant and the north-west borders of India, ${ }^{1}$ are $3 d$ countries. In considering the last-named, the exploits of Xenophon, Alexander, and Timurlane remind us of the enormous interest of the greatest of the world's highways of migration. It is the platform on which East and West have over and over again wrestled before the gaze of the world.

6. Areas marked 4 are tropical.-4a represents west tropical deserts. The Atacama waste of South America, the Colorado region, the Sahara, the Arabian plateau, the Thar of India, the Kalahari in South Africa, and a great deal of the interior of Australia, belong to this category. Mountain ranges, situated so as to interfere with the passage of moisture-laden air from the ocean, and the unfavourable direction of winds, produce desert conditions. In the case of

${ }^{1}$ We use the term loosely. Iran, properly so called, is the central portion of this plateau. 
America, the prevailing breezes in the latitudes under consideration are parallel to the coast : off North Africa the prevailing direction is north-east, so that Central America is drenched, and the Sahara receives less than 10 in. of rain per annum : off South Africa the Trades blow in a south-easterly direction, and similar conditions are to be noticed in the case of Australia. In all cases there is a general, but not total absence of vegetation : that which does exist has a character of its own. The plants occur in comparative isolation: the leaves are scaly, sword-shaped or tufted, ${ }^{1}$ or, more frequently, they are thorny. The familiar cactus, in many varieties, is a typical plant. The roots are enormously long, in order to reach the occasional springs far below the generally shifting surface. The larger deserts are fringed by poor steppes, and the poor steppes in their turn by land fit for pasture. When underground drainage reaches the surface, oases occur, and make it possible to use certain highways. History, therefore, is written in some of these lands, and the men of North Africa and Arabia have done great things. They have triumphed over physiographic disadvantages, mainly through the influence of a magnificently fanatical religion, and they are almost purely military in their characteristics.

Lands marked $4 b$ are of the east tropical or monsoon type. This means that they are affected by the great seasonal winds, called monsoons. Central America has

1 Marr, Scientific Study of Scenery, p. 267. 
already been referred to: Brazil has the benefit of the south-east trades: East Africa has a similar set of winds in the south, while, in the north, it shares with India, Indo-China, and the islands near, the double set of monsoon winds. These blow from the polar regions, and become north-easterly owing to the earth's rotation, until counteracted by the south-west or wet monsoon. This is caused by the indraught of air from the ocean to fill up the partial vacuum caused by the rising of heated air in the summer from the centre of the great Asiatic continent. Rain is torrential and vegetation abundant. Rice may be selected as a typical crop. Man is mainly of the black type, except in Eastern Asia, where the yellow race is found. Races belonging to the former are sometimes called the subject races, and the term is correct in so far as it means that they have been conquered, and their lands occupied, by the white man. Whenever they have withstood the progress of civilization, they have suffered, like Stephenson's " coo." Races belonging to the latter comprise the most ancient of cultured peoples. Population is very dense, and the possibilities of the yellow races are unknown. The rise of Japan of late years has been phenomenal, and China, too, seems to be waking up. The Far East has a great future.

7. Lands marked 5 are lofty tropical or sub-tropical mountains.-The main areas are the central Andes and Tibet. Inhabitants are few and vegetation -is sparse, 
for climate is rigorous. In consequence, the main features only are known, and there is much work for explorers to do yet. Gradually, however, the map is being filled in, and each year brings some fresh triumph of bravery and endurance. The main interest of Tibet is political, and this is the direct result of its geographical position upon the borders of three great empires, the Russian, the Chinese (of which it is a part), and the British. Hence the benevolent attention paid to this ill-favoured region.

8. Lands marked 6 are Equatorial lowlands.-Four features may be observed with reference to the three regions marked 6. They are all about the Equator: they are all relatively low in elevation: they are, in consequence, very hot: they have a very abundant rainfall. The result is a very trying climate, much reeking swamp, and a tremendous density of vegetation. The tropical rain-forest is a mass of enormous trees, connected by a tangle of creepers, and teeming with life of all kinds. It is the natural home of degraded and ignorant savages, and, appropriately enough, the Congo has gained for its continent the name of "Darkest Africa." Some very fine illustrations of the vegetation are to be seen in Schimper's Plant Geography (Clarendon Press). The indiarubber-tree is one of the chief commodities of commerce. The three regions are the Amazon, the Congo and the great archipelago which connects Asia and Australia, The January temperature 
throughout is the highest in the world, and that of July is only less than the fierce heat of the large inland deserts. Naturally enough, this type of terrain and its inhabitants have not welcomed outsiders with open arms. Its history is often the story, often the tragedy, of exploration, followed by the exploitation of the land for trading purposes. Much may be done, especially in the Amazonian country, by clearing forest land, to give a very large surplus population an abiding home, and the 6 lands will not be forgotten in the history of the future.

9. Summary.-It will be well to recapitulate the preceding paragraphs here, in order that the student may be able to refer rapidly to the major regions with the help of the map at the end of the chapter. We therefore append Mr. Herbertson's brief explanation, slightly revised to meet the requirements of the changes he has made in the illustration. "Premising that the lines on the map are taken as the approximate central lines of the transition areas, we may divide the world up into the following types of natural regions :-

“1. Polar. (a) Lowlands (Tundra type); (b) Highlands (Ice-cap type).

“2. The cool temperate regions. (a) Western margin (West European type); (b) Eastern margin (Quebec type); (c) Interior lowlands (Siberian type); (d) Interior mountain area (Altai type).

“3. The warm temperate regions. (a) Western margin 
with winter rains (Mediterranean type); (b) Eastern margin with summer rains (China type); (c) Interior lowlands (Turan type); (d) The plateau (Iran type).

“4. (a) The west tropical deserts (Sahara type); (b) East tropical lands (Monsoon type).

"5. Lofty tropical or sub-tropical mountains (Tibetan type).

"6. Equatorial lowlands (Amazon type)."

10. Warnings.-It must be carefully remembered that, though we have briefly sketched the varying occupations of men who live in diverse parts of the world, there is a distinct danger of overrating the effect of environment upon man. It is unsafe, too, to say that certain causes produce similar effects wherever they are found. This is very far from being the case. It is most interesting to trace the way in which the ancient Athenians cultivated the artistic and the beautiful, encouraged by their maritime position, their salubrious climate, and their familiarity with beautiful scenery. We look in vain for those qualities to-day, though physical features remain unchanged. Again, Bacon says : " It is manifest that the northern tract of the world is in nature the more martial region, . . . in respect of the cold of the northern parts, which is that, which without the aid of discipline, doth make the bodies hardest and the courage warmest." This is a very inviting statement, but it will not for a moment

1 Essay lviii. 
bear the test of history, ancient or modern. The Romans and the Saracens only need to be cited to dispel such ideas. The Zulus and the Matabili, the reckless heroes of the Sudan, the Mahrattas, who conquered from Poona to the Indus, the Ghurkas, the Sikhs, the Japanese, all contradict the statement. "The men of Cornwall and Kent are no whit inferior in any respect to the dwellers north of the Highland line, and never have been so. In the American war the men from Texas, Georgia and Carolina fought far better man for man, with inferior weapons and resources, than the men from Boston, New York, Chicago or Pittsburg." 1 The Russians in 1877 were far surpassed, says an Italian authority, Carlo Porro, by Asiatic Turks in staying power during the hardships of that campaign. A bad climate cannot destroy the good of religion or true patriotism, nor will a good one in any way "avail licentious monarchies or corrupt democracies." Indian hill tribes vary enormously. The people of Scinde and Kashmir are far inferior to the Beluchis, Pathans, and Dogras. Plains produce heroes and patriots as well as mountains. Poland is an instance. It may be said that the Prussians owe their strong position, in a military, commercial, and intellectual sense, to organization; but the Red Indians of the Mississippi basin can be favourably compared with any race of any time. The Chukchis of Bering Strait will risk their lives in

1 Maguire, Military Geography, p. 326. 


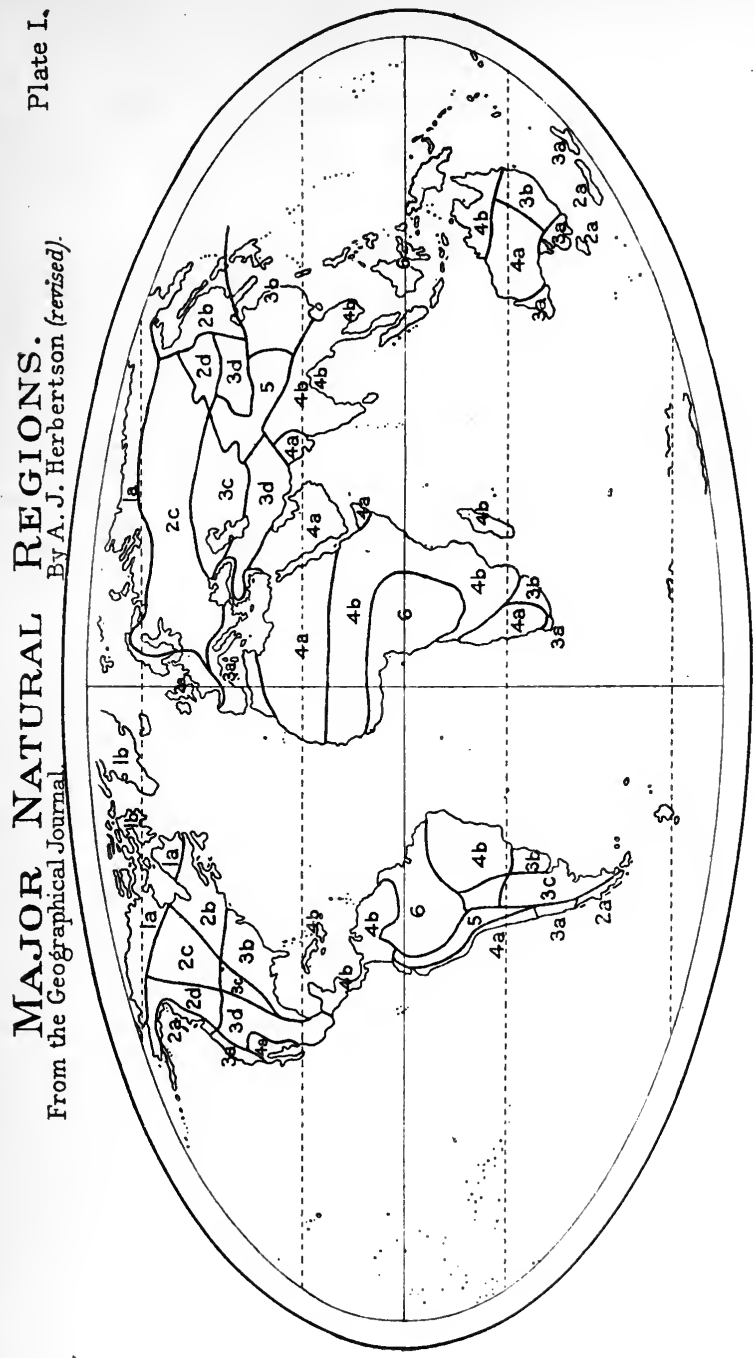



heavy seas in their flimsy bidarras, and display in the search for food or skins qualities of seamanship and adventure that would have done credit to a Drake or a Togo.

Yet climate and conditions of life count for something. The Norwegian has a hard struggle for existence: unremitting labour on made ground produces a small crop which may be ruined, for all his care, by heavy rains, and he lives in a gloomy though beautiful land. He has no luxuries; and so we find him somewhat sombre in disposition, but very humane and scrupulously honest. Most peoples who are shut in by mountains are clannish, intolerant of outsiders and, in the state of nature, savage. But enough has been said to show that, while history is profoundly affected by physical features, there are as many exceptions as rules; and one must not be too ready to generalize. 


\section{CHAPTER III}

BRITISH ISLES-REGIONAL GEOGRAPHY

1. Arbitrariness of Regional Divisions.-It is often stated, especially by American physiographers, that there is no justification for treating the British Isles as a geographic unity. These isles are merely an isolated portion of the continental shelf of Europe, and possess no distinctive physical characteristics. Scotland is merely a piece of Norway, the Thames basin is merely a subsidiary part of the Rhine, Eastern England is practically identical with Western Holland, Dover is Calais over again, and Cornwall is Brittany. It must be confessed that this criticism is wholly just; and what is said with regard to structure is almost equally true when applied to climate.

2. The British Isles an Historical Region.-In this work, however, we have the historical aspect of geography constantly before us. No critic, however keen, can deny us an historico-geographical unity. England the objective, Scotland and Ireland the stepping-stoneshow often has history told that story? Warbeck used Ireland. So did Philip of Spain, and James II. 28 
Scotland was of use to Charles II, to the French many times during the Hundred Years' War, and to the Jacobites. Our insularity, in the titanic struggles of the past, has been of absolutely vital importance. No student of any age needs reminding that, in our darkest days of national humiliation, the one fact that has stood between us and extinction has been the existence of a strip of sea between us and the enemy. Having this in view, we do not hesitate, either to treat our little country as a region, or to divide it into subsidiary regions.

3. The Highlands of Scotland.-The first physical division to which we call attention is Northern Scotland. This extends from the Shetlands to Strathmore and the Clyde, and from the Outer Hebrides to the east coast. The prevailing structure is Archæan, the greater portion of the earth's crust in this part being composed of very hard and very ancient rock, carved by the weather into valleys which seam the great block into long, winding furrows. The western side is penetrated by long arms of the sea, the shape of which is due to the drowning of the land. These are called firths or fiords. Seen from below, the land is intensely complicated. Viewed from above, it is remarkably uniform in height. There is no mountain range, and the whole presents the appearance of a rounded and flat-topped moorland, covered with heather and mosses, these giving place occasionally to deer-forests. The whole has been 
greatly modified by the glaciers of the Ice Age. Rocks above two thousand feet remain sharp and serrated. Down lower they are round and hummocky, and, when favourable, covered with till or boulder-clay. The predominant vegetation is moorland and hill pasture. Hence population is scanty, and always has been, and the tendency has been towards the creation of clans and blood-feuds. A sturdy independence, violated once in 1746, has always been the heritage of Northern Scotland.

4. Topography of the Highlands.-The poverty of the land and its physical difficulties make communication difficult. The west coast attracts tourists, and the east affords trade in granite and fish. Railway lines reach the west coast at Oban, Mallaig, via Fort William, and Lochalsh, viâ Strome Ferry. These lines pass through few places of importance, and cannot compare with those of any other part of the country for traffic, except in the summer. The Oban line (Caledonian) passes Callander, the Pass of Leny, Loch Lubnaig, Loch Earn, Glen Dochart, Strath Fillan, and the northern end of Loch Awe, down Loch Etive to the sea. The Mallaig route leads from Glasgow and Dumbarton into the valley of the Gareloch, and skirts Loch Long. It then traverses the northern or narrow part of Loch Lomond, crosses the Oban line at Crianlarich, skirts Glen Orchy, and passes near the mountains of Glen Coe in its passage of the desolate Moor of Rannoch. Following the valley of 
Loch Treig, it descends into Glen Spean. Emerging from the foot of the valley it reaches Fort William, at the foot of Ben Nevis, passes along Loch Eil, reaches the coast at Loch Aylort, and turns northward past Loch Morar to its terminus. The third line is from Inverness through Beauly to Dingwall, and thence westwards viâ Loch Luichart, and the Carron Valley to Strome Ferry and Lochalsh. Through the middle of the region a line runs from Perth to Dunkeld, Pitlochry, the Pass of Killiecrankie, Blair Atholl, Kingussie, along and across Strath Spey, across the Findhorn and the Nairn to Inverness, thence to Dingwall, Tain, Lairg, Golspie, and across the Old Red Sandstone plain of Caithness to Thurso and Wick. The North British line bridges Forth and Tay on its way to Aberdeen along the coast. Thence Elgin and Inverness are reached viâ Huntly. These routes, and one from Perth and Crieff to Oban, are the only ones in the Highlands worthy of mention, and only that to Aberdeen and Inverness (cf. the march to Culloden in 1746) is free from serious difficulty. The whole region is cut in two by the wonderful fault-valley of Glenmore.

5. The Rift Valley.-The part of Scotland between the Highlands and the Southern Uplands was formed by the down-sinking of a great block of strata once flush with the uplands to the north and south. The chief features are a well-worn highway from Glasgow to Edinburgh, a broken string of heights, running, 
according to the grain of the land, from south-west to north-east, and consisting of the Dumbarton Heights, Campsie Fells, the Sidlaws and the Ochils, and the fertile valley of Strathmore. This is the most prosperous district of Scotland, and has played a most important part in its history. The coal-measures cover more ancient deposits, and lie in a trough surrounded by older rocks. The presence of this mineral and the ease of communication, coupled with the harbour facilities and the continental vis-à-vis of the Forth and Tay, have caused a wonderful concentration of population in this region. Particular note must be taken here of Stirling, the key to the Highlands, and, next to Berwick, the greatest bone of contention between English and Scot.

6. The Southern Uplands.-The third region of Scotland extends as far south as the Cheviots, Carlisle and Berwick being the border towns. A great deal of sentiment, and no small amount of history, attach to this country. The writings of Scott, the poems of Burns, the debatable character of the terrain, and the frequent collisions of clan and clan, nation and nation, within its limits, make the Southern Uplands a land of special interest. Physically it is a difficult country, but its tracks are well beaten owing to the exigencies of its buffer position. The best-known highway is the east coast route, from Berwick and Dunbar to Edinburgh. Carlisle is a great centre. North-east- 
wards a line climbs the Esk and Liddell Water to Riccarton, Hawick, Melrose, Greenlaw and Duns to the track just mentioned. Due north the Caledonian main line toils up Beattock Summit, following the Annan Valley till it can cross to the Clyde. At Carstairs it divides for Edinburgh and Glasgow. The Nith Valley has a line leading through Dumfries and Sanquhar to Kilmarnock and Glasgow. Lastly, from Dumfries a track leads westwards to Dalbeattie, Castle Douglas, Newton Stewart and Glenluce, either continuing thence to Stranraer or Port Patrick, or forking northwards to Girvan, Ayr, Paisley, Glasgow and Greenock. 'The district is almost wholly agricultural, and sheep-farming is characteristic.

7. The North of England.-The predominant feature of the North of England is the Pennines. They consist of a great arch of Carboniferous rock, the heart of mountain limestone, the heights of flat moorlands of millstone grit, and the sides of the coalmeasures, which have been denuded from the top of the anticline. To the east are to be noticed the northern outliers of the Jurassic (oolitic limestone, etc.) and Cretaceous (chalk) systems, and to the west lies the Lake District, geologically reminiscent of Southern Scotland, and separated from the Pennines by the Eden Valley. The chief routes are all of them very important in Anglo-Scottish history. The simplest is that which traverses the Vale of York and aims at 
Edinburgh along the narrow coastal plain. The Great Northern and North-Eastern railway lines outline this, through Grantham to Doncaster, York, Northallerton, Newcastle, Berwick and Dunbar. On the opposite side of the range the routes are not so easy. The North-Western line stretches from Crewe northwards to Warrington, and thence to Preston, Lancaster and Carlisle. How repeatedly these highways have played their part we will show in another chapter. Another track-the Midland-takes advantage of the Aire Gap. Leaving Sheffield, it goes by Leeds and Skipton to Settle, passes to the east of Whernside and Baugh Fell, and reaches Carlisle viô Appleby. There is also a way across from Newcastle to Carlisle by the Tyne Valley, Hexham and Haltwhistle.

In the north-east, the Tyne is the most important feature. Upon its banks stand several important towns, Newcastle, Gateshead, Wallsend, Jarrow, North and South Shields. The Wear has on its banks venerable and historic Durham, and Sunderland, which, with the Tyne towns, depends for its prosperity upon the large local deposits of coal and iron. The Tees, too, reminds us of similar phenomena in connection with Stockton, Darlington and Middlesbrough.

On the opposite coast, on the edge of the beautiful Lake District, coal again crops out, giving rise to Maryport, Workington and Whitehaven, and affording facilities for the ship-building trade of Barrow. 
The basin of the Yorkshire Ouse consists of a series of lovely dales, some adorned by the ruins of mediæval abbeys, which yield up their waters to be polluted by the mill-refuse of dozens of woollenmanufacturing towns. The fertile Vale of York unites the waters of the Swale, Ure, Nidd, Wharfe, Aire-Calder and Don in the Humber estuary. The Derwent from the north-east, the Hull, and the Trent (which girdles the Southern Pennines), also drain into the same mouth. The woollen manufactures of Leeds, Bradford and the rest of them, and the cutlery and weapon manufactures of Sheffield are well known.

To the west lies Lancashire, a large and straggling county, the southern portion of which belongs to what is sometimes cryptically called the "Cheshire Plain." This lowland will be found to be of great importance historically. London is easily connected by highways with the Midlands. The low plateau on which Birmingham stands is bounded on the south by the Cotswolds. To the west lie the Severn and the Welsh hills. To the north the Pennines rise out of the plain and culminate, in that part, in the flat-topped, lonely millstone-grit moorland of Kinder Scout (2008 feet), known to the general public by the corrupted name of "The Peak." To the north-west the land is flat as a rule. The Triassic Sandstones, underlain in places by salt deposits, and supporting the abundant tilth of Cheshire, reach the sea in a dune coast which 
looks towards the Dublin lowland, and farther north dip beneath the coal-measures of one of the most remarkable manufacturing regions of the world. The wonderful port of Liverpool, the great distributing centre Manchester, and the enormous ring of subsidiary towns, all mainly engaged in producing $£ 92,000,000$ worth of cotton goods per annum, constitute a little region remarkable for its extreme specialization, its enormous wealth, and its restless energy.

8. Wales and the Devonian Peninsula.-The west of Great Britain consists of a mass of high land consisting of Palæozoic rocks, the massive slates of Wales being the most conspicuous, with frequent igneous intrusions, such as the lavas of the Snowdon range, the porphyry of Cader Idris, and the granite bosses of Dartmoor and Exmoor. The whole region is wild and broken, and presents serious difficulties of communication. The main routes are few. The Great Western Railway has one main line making south-westwards from Swindon to Bath and Bristol. Here it divides, and that for South Wales passes through the Severn Tunnel, travelling along the coast through Newport, Cardiff, Swansea, Llanelly and Carmarthen for Milford or Fishguard, the latter affording a short route to Rosslare, near Wexford. The Cornwall line makes for Exeter by Taunton or the new Castle Cary cut, and then travels along the shore to Plymouth, Truro and Penzance. The South-Western Railway passes Basing- 
stoke and Salisbury, travelling inland from Exeter to Plymouth, north of Dartmoor. The North-Western line from Crewe to Chester passes Rhyl and Conway, crosses the Menai Strait and transfers its Irish passengers to boat at Holyhead. This same railway has also a monopoly of traffic from north to south, from Wrexham and Shrewsbury to Welshpool, Llandiloes, Rhyader, Llandovery and Llandilo to the coast, while the Cambrian Railways do a fairly brisk traffic along the littoral about Aberystwyth.

Commercially, the most notable feature of this part of our little home land is the extensive and valuable deposits of anthracite or hard steam coal in the South Wales trough of carboniferous rocks. The massive slates of Penrhyn and the Wrexham-Ruabon coal, and the weaving of woollen materials, chiefly flannel, of very high quality, also claim attention. The cloths of Somerset and the dairy produce of Devon, and the fine cattle of Herefordshire, complete the tale, for the mines of Cornwall are mainly a thing of the past. Fishing is very important round all these coasts.

9. The Midlands and South-East England.-The Lancashire-Cheshire plain, mentioned on page 35, is practically unbroken till it reaches the oolite hills of Gloucester, Oxford, Northampton and Lincoln. It merges insensibly into the central plain of England. This is composed almost entirely of Triassic or New Red Sandstones. It reaches the Humber on one side 
and the Lune on the other-strictly speaking, indeed, it touches the Tees, viâ the Vale of York-but we will use the term "Midlands" somewhat loosely and arbitrarily. The western portion is conspicuous for the great manufacturing centres of the Potteries and the Black Country. Stoke, Hanley, Burslem and other towns occupy the southernmost spurs of the Pennines, while Birmingham, with its vast ring, or rather cluster, of satellite towns, stands on a low plateau bordering the Clee and Clent Hills of Shropshire and Worcester. In the centre, Derby, Nottingham and Leicester are notable manufacturing towns of the first class, and the Soar and the Trent flow to the north through the Vale of Nottingham, past Gainsborough.

Bordering this country, and running from Dorsetshire north-eastwards to Redcar at the mouth of the Tees, runs a persistent band of limestone rocks of Jurassic or Secondary age. These include such deposits as the Lias, used extensively as road-metal, the oolites, which make a handsome and easily workable building-stone, and the Oxford and Kimmeridge clays. The main routes in this region, from the nature of the case, cross the grain of the land, that is, run at right angles (or nearly so) to the south-west to north-east trend of the escarpments. Most of the rivers, on the contrary, follow the direction or strike of the hills. The Trent curves round the southern end of the Pennines and 
flows to the Humber by way of the Vale of Nottingham. The Warwick Avon skirts the north of the Cotswolds on its way to the Severn.

Similar conditions prevail in the case of the great chalk escarpment. This, excluding a considerable patch in the East Riding and Lincolnshire, runs from Norfolk to Dorset. The East Anglian Heights, the Chilterns, the Marlborough Downs and the Dorset Heights are the different parts of this system. Between them and the oolitic hills is a band of clay, and over this and the lower parts of the bordering formations run the Nen and the Great Ouse, together with parts of the main stream and some of the tributaries of the Thames. Over the eastern chalk strata, and forming a large delta, lies the London clay. The Thames, in its middle course, cuts its way between the Chilterns and the Marlborough Downs; but this is the only conspicuous instance of a natural highway from side to side of a range in this part of the country. Hence it is that the Romans, at Dunstable, cut through a chalk hill to conduct their great road, Watling Street, to the northwest. Hence it is, too, that all the great railway lines have an awkward rising gradient of rather trying length to surmount on their way out of London, and some are compelled to tunnel through the hills-the Great Northern at Hadley Wood, the Midland near Elstree, and the North-Western beyond Watford. The Great 
Western follows the Thames, and thus obviates the difficulty, and the Great Eastern follows the Lea and the Stort on its way to Cambridge.

The main occupation of the people of these scarp lands is agriculture. Sheep are reared on the uplands, while mixed farming prevails in the valleys. In the Eastern counties, owing to the dryness of the climate and the nature of the soils, a great deal of wheat is grown, and Norwich is a centre for the manufacture of agricultural implements. A few minor industries flourish in this region. The gloves of Woodstock, the blankets of Witney, the chairs of High Wycombe, and the strawplait of Luton and Dunstable, afford a variation from the generally bucolic nature of men's occupations. The great universities of Oxford and Cambridge also stand within this country, while other phenomena are due to the nearness of the metropolis. London will be dealt with separately.

10. The Weald.-The Weald is generally regarded as a physical unity. In structure it is a dome of chalk stretching from Salisbury Plain to the sea, with the central part stripped away by denudation, leaving the escarpments of the North and South Downs facing each other over an undulating terrain consisting of Gault clay, Greensand and Weald clay. A strip of flat land runs from London through Rochester, Canterbury and Dover, north of these heights. This physical feature, traversed by the Roman Watling Street in 
early days, when the Weald was too densely forested to be comfortably traversed, and by the South-Eastern and Chatham Railway to-day, is historically of the most urgent importance. As we are to deal with London separately, we make no further reference to it here. (See p. 60.)

The orographical structure of the Weald, with its double escarpment running roughly parallel to the coast, makes highways from the metropolis to the coast by no means devoid of incident. Several forts of doubtful utility, which will probably be demolished, face the south, and are no longer expected to make the passage of the few gaps difficult to an invader. Roads from London have severe gradients in Surrey and Kent, and railways are compelled to burrow through the chalk in moderately long tunnels. The Portsmouth branch of the London, Brighton, and South Coast Railway disappears underground for a time just beyond Dorking. The main route to Brighton has a long cutting and tunnel at Merstham, another at Balcombe, another at Hayward's Heath, and another near Brighton. The joint line to East Grinstead has a long tunnel to the north of Oxted. The Tonbridge line has three, the longest at Sevenoaks. These facts serve to show the difficulties of the region, slight though the heights are, no point rising to 1000 feet above sea level. There are a few gaps, and these are important. Guildford stands where the Wey notches the Downs, 
and Dorking faces Box Hill, where the Mole ceases to be a longitudinal or strike stream, and boldly cuts through to Leatherhead. Redhill stands on a dry gap in the range, and Reigate spreads itself in the hollow above which the old Brighton Road crosses the Downs by a notch more than 600 feet above the sea. Near Sevenoaks the Darent has carved a valley which aims at Dartford, while the Medway marks its passage through the range by the town of Maidstone, leading to Rochester-Chatham. In the south the Arun breaks through at Arundel, the Ouse between Of'ham Hill and Cliffe Hill at Lewes, and the Cuckmere at Alfriston. One long trench, marked by the Reading branch of the South-Eastern line, passes longitudinally from beyond Aldershot, through Guildford, Reigate, Tonbridge and Ashford, to Folkestone and Dover; but this leads from the upper Thames or the Kennet, and does not concern London.

The whole district is well known on the one hand for its sheep, which feed on the dry chalk slopes, and for the highly developed fruit culture of Kent. The scenery is lovely, and the coast towns have seen some of the most vital and stirring episodes in our island history.

11. Ireland.-Ireland is approached from Great Britain, or Great Britain from Ireland, by a variety of routes. Those used by regular lines of steamers are marked in many maps of the British Isles. It will be 
useful to notice some of them now, in view of the past and the future. The classic crossing is that from Holyhead to Dublin, sixty-four miles in length. The Great Western Railway's steamers from Fishguard in Pembrokeshire to Rosslare, near Wexford, bid fair to compete strongly with those from North. Wales. From Holyhead, too, the journey to Greenore in Carlingford Lough is less than eighty miles. Cork communicates naturally with Bristol, the distance being 255 miles, while Liverpool is not much farther away. From Barrow to Belfast is $\mathbf{1 0 0}$ miles, while the distance from Glasgow is nine miles longer, and only forty-one miles separate Stranraer and Larne. Ireland is unfortunate in having her best natural harbours on the far side of the island, and without a prosperous hinterland. The eastern ports owe most of their importance to their nearness to the Mersey and the Clyde. The island is deficient in coal and iron, and the more important occupations of the people are rural. Belfast is the chief, almost the only, industrial centre.

The centre of Ireland is a plain of peaty land traversed by a drainage which, owing to the evenness of the surface, is rather bewildering. Communication with the coast in all directions is easy, as the greatest heights of land are on the edges of the island-the complex ranges of Donegal in the north-west, the Antrim heights and the Mourne Mountains, separated by the Lagan, in the uorth-east, the Wicklow mass on 
the south-east, the numerous ranges of Munster in the south-west, and the Nephin Beg and Connemara Mountains descending almost sheer to the sea far away to the west.

The main routes are few and simple. Dublin, the historic capital, communicates with Cork by way of Kildare, Maryborough, Templemore, past Tipperary, (on the Limerick-Waterford line), round the Galty Mountains, across the Blackwater at Mallow, and so past Blarney to the harbour. The Limerick branch of this line-the Great Southern and Western-goes to Sligo by way of Ennis, Tuam and Charlestown in Mayo. Dublin connects with Galway by way of Mullingar and Athlone, and with Wexford viâ Kildare, Athy and Carlow. The Great Northern (Ireland) connects Dublin, Drogheda, Dundalk, Portadown and Belfast, and northwards the route is not difficult to Antrim, Ballymena, Coleraine and Londonderry. The Dungannon coal-field is reached from Belfast by a line passing through Lurgan, and Sligo is on the way past Enniskillen.

The main drainage-lines are those of the Shannon, which widens out into Loughs Allen, Ree and Derg, and discharges its waters into the sea by a very long estuary starting at Limerick: of the Bandon, leading to the sea at Kinsale : of the Lee, passing Cork : of the Blackwater, which empties into Youghal Bay: of the Suir, Nore and Barrow, discharging into Waterford Harbour: of the Slaney in Wexford: and, in the 
north, of the Bann and the Foyle, which reach the coast at Coleraine and Londonderry. The eastward flow from the central plain is largely diverted by the Shannon, but the Liffey and the Boyne, modest streams that they are, have played an important part in the history of Ireland. For the rest, the climate is mild and moist, the land is fertile, and the people poor. Population is rather scanty, and suffers depletion from emigration. The reasons for this are mainly political, and are out of our province here.

12. Summary.-Such, then, is a brief survey of the regional geography of our islands. A good deal of stress has been laid throughout on communications, and if the student has followed the routes carefully with a good atlas and has revised them by going over them on Plates III, IV, V and VI, he will have grasped the details of physical configuration which are absolutely necessary to the understanding of the chapters which are to follow. Let him take special note of the east and west ccast roads to Scotland, of the Midland Gate through Cheshire, and its relation to the Dublin lowland, of the South Wales coastal plain, and of the approaches to London. A thorough mastery of the topography of these features will be rewarded by an intelligent interest in the events which they have shaped. 


\section{CHAPTER IV}

THE BRITISH ISLES-MIGRATIONS

1. Early Britain.-The earliest inhabitants of Britain were probably Iberians, now represented in Europe by the Basques of the Pyrenees. The Goidelic Celts were the first group of invaders, and overran England, Scotland and Ireland. Many of the Southern Welsh, the men of Cornwall and Devon, the Highlanders and Irish are sprung from them. The Brythons followed these men, and drove them back, and were in possession of most of the country in 55 B.c. As so very little is accurately known of these peoples it is useless to treat of their history from a geographical point of view ; and, chronologically, our study will begin with the Roman invasions.

Let us first see how our islands are situated as regards neighbouring countries, and where foreigners were most likely to land.

2. Approaches to Britain.-It must be remembered that the early invaders had no maps of any kind, and therefore had no means of gaining foreknowledge of the ground they had to traverse. Hence they were com46 
pelled to follow the trend of the physical features of the country, to sail up the rivers, to follow the roads (after Roman times), and to skirt the forests.

In order to study the trend of invasions we must look at the physical map at the end of this chapter, which shows the physical relation between England and neighbouring countries, and the entries to our lands. To the west we have a wide ocean, and, moreover, our coasts are, though well indented, not very hospitable and terribly exposed. Sir Archibald Geikie tells us ${ }^{1}$ that on Skerryvore, a rock to the south-west of the island of Tiree, and exposed to the full force of the Atlantic, the breakers have a force of $611 \mathrm{lbs}$. to the square foot in summer and $2086 \mathrm{lbs}$. in winter, not to mention $6083 \mathrm{lbs}$. during a great gale. The Spaniards, too, found in 1588 that these same shores were very cruel.

3. The Spanish Armada.-To the south lies Spain. On one occasion we suffered invasion from her shores, and the course of the Armada was quite straightforward and just what one would expect. Ships starting from Cadiz passed Capes St. Vincent, Roca and Finisterre, crossed the Bay of Biscay and entered the Channel at its south-western end. The Duke of Medina Sidonia was ordered to effect a junction with Parma, who was stationed near Dunquerque, and then to sail up the Thames to London. This was prevented by the 1 Scenery of Scotland, p. 78. 
celebrated attack of eight fire-ships upon the Spanish fleet, and a battle took place off Gravelines which caused Sidonia to flee northwards. The English fleet escorted him as far as the Firth of Forth, to make sure that he did not attempt a landing in Scotland, and then turned back. The Spanish vessels were then directed to double the Shetlands, steer to the north-west of Rockall, thence south-west to lat. $53^{\circ}$, and finally to make for any port of the coast of Galicia. One vessel was lost on Fair Isle, two on the Scottish coast, one in the Sound of Mull, one on the Outer Hebrides, two were blown into the English Channel, fifty-seven returned to Spain, and twenty-five were lost on the coast of Ireland. 1

The wind being in the north-east, the Orkneys were passed and then Ireland was sighted: but the wind veered to the south, and the whole fleet turned northwards. Later, a great storm arose and some vessels found themselves in $53^{\circ}$ north latitude. Sidonia and the ships that were in least straits then made for Spain, but a great many ${ }^{2}$ (Lord-Deputy Fitzwilliam said fifty-seven) were compelled to turn to the nearest land, being in desperate case for fresh water. A south-westerly gale followed, and all the ships dropped in upon the Irish coast within five days of one another. Recalde anchored under the lee of Great Blasket Island, and

1 Wm. Spottswood Green, Geographical Journal, May, 1906.

2 State Papers, Ireland, vol. 136, p. 43. 
finally got home in safety, while five ships reached Scattery Roads in the Shannon estuary and left without mishap. Most, however, were wrecked and their crews as a rule slaughtered-a very cruel but quite necessary step, for Sligo and Donegal, where many of the wrecks took place, were in the hands of men who, with very little encouragement and with prompt help from Spain (which was not sent), inight well have snatched the whole of Ireland from our grasp.

Such was the fate of the Invincible Armada, the great invasion which came from the far South.

4. The Channel Shores: West.-A study of both coasts of the Channel will reveal several instructive points. Our Cornwall and Devon coast is well indented, and contains many good harbours. It seems to have been much used in early times by foreign traders anxious to purchase lead and tin from the then valuable mines; strategically, however, it is too remote a part of the island to afford an obvious striking-point. The opposite coast, too, the rocky shore of Brittany, is too far away to enable a foe to deliver his attack with any degree of suddenness. Hence the south-west coast of England is rather neglected in history; but it has been used when circumstances made it impossible for an attack to be made at the heart of our country.

Just before the fateful battle of Tewkesbury, Margaret landed at Weymouth, in order to effect a junction with her supporters from the Welsh border. 
Hence the battle which caused her overthrow. Perkin Warbeck, on the other hand, landed at Whitesand Bay, just north of Land's End, thus giving Henry VII ample time to send troops to crush him. The pretender failed to capture Exeter, took to flight and was finally taken at Beaulieu in Hampshire. Monmouth's rising in 1685 shows features not unlike those just noted. Monmouth landed at Lyme Regis, and was crowned at Taunton. It was when he made a half-hearted attempt to reach Bristol, in order to effect a junction with his Cheshire supporters, that he found his kismet at Sedgemoor. $\mathrm{He}$, too, made off eastwards, and, like Warbeck, he was taken in the New Forest. It will be remembered, too, that William of Orange landed at Torbay, and marched on Iondon, gathering adherents as he went. Such is the part that our south-west coast has played in our annals. But no Englishman needs reminding of the magnificent work done by the men of Devon in the reign of Queen Elizabeth, of Drake and Grenvil, and the rest of them; and the Devon men of to-day have shown both in war and sport that they can still uphold the best traditions of their forefathers for grit and endurance-qualities bred of their pure highland air and strong sea-breezes.

5. The Channel Shores: East.-The Channel is abruptly divided in longitude $2 \frac{1}{2}^{\circ}$ by the Cotentin Peninsula. Between this and Cape Gris $\mathrm{Nez}$ on the one side, and between Portland Bill and Dungeness on 
the other, there lies a very narrow sea, which has over and over again been the scene of migration and strife. The natural highway is from the mouth of the Seine to Southampton Water, though it must be said that the approach from Southampton Water to the Seine is a far more attractive prospect, as the Seine forms a path into the heart of France, while nobody can give the Itchen any such dignified title on its part. As the seas contract eastwards, physical conditions tend more and more to make Hastings, Dover, Deal or Folkestone the obvious places for descent on our shores, but this is partly balanced by the fact that the chalk tableland of the mainland is cliff-edged, corresponding with the well-known Kentish promontory. "Here the Teutonic Fleming yields to the Latinized Gaul of Picardy, essentially a landsman, and the firm soil is notched only by a few small harbours, and has no border of marsh or tidal lagoon. Britain has had to suffer no serious invasion from Picardy or Flanders." 1

In 519 the Jutes effected a settlement in Hampshire and seized the Isle of Wight. From this occupation of Hampshire the West Saxons gradually extended their kingdom; but that is another story. Between 860 and 866 the Danes were ravaging Wessex, probably along similar geographical lines. In 987 the unfortunate Ethelred the Unready had to submit to the plundering of Southampton by a fresh set of invaders. These men

1 Mackinder, Britain and the British Seas, p. 19 
came across the seas owing to the growth of Denmark, Norway and Sweden into separate kingdoms, which, being poor and small, were unable to provide adequately for their increasing population. In 1066 William of Normandy landed at Pevensey, having sailed from the Seine mouth, and on October 14 of that year the famous battle of Senlac was fought. The further course of the Conqueror will be traced in another chapter. (See p. 62.)

At the beginning of the reign of Henry III, too, a French fleet came over to put Louis on the throne. It was met by Hubert de Burgh off Sandwich, and defeated. Louis was besieged in London by William the Marshal, and compelled to agree to leave for France, thus demonstrating how easy it is to get into our country, but how difficult to get out again.

Lastly, after a wide chronological gap, we come to Napoleon's great projected invasion of our shores. As no such invasion took place, it is the fashion rather to underestimate the danger which then threatened us. Napoleon's plan was no wild chimæra. He collected a flotilla of flat-bottomed boats at Boulogne, and encamped picked soldiers from the Armies of the Rhine and Italy upon the coast. He endeavoured to unite the two French fleets which were concentrated at Toulon and Brest, and summoned the Dutch and Spaniards to get fleets together also. He also kept 120,000 veterans continually at work practising em- 
barkation and disembarkation. He certainly paid us the compliment of making very thorough preparations. It was only necessary for him to have control of the Channel for less than a day, and to have reasonably fine weather, for his project to succeed. Villeneuve, too, failed when he might well have been expected to succeed, or the Brest fleet might have broken through the irritating blockade to which it was subjected. It is interesting, if futile, to speculate as to what would have happened if the Emperor had effected a landing.

6. The East Coast, excluding London.-As London and its approaches are separately treated in the next chapter, we will exclude them for the present, and consider the rest of our east coast. Again it is necessary to inquire into the question of vis-à- $\imath i s$, and to see what lies opposite the shores we have named. The Thames estuary faces the lowlands fringing the mouth of the Rhine, while the Wash and the Humber are most easily reached from the mouth of the Elbe and the Danish coast. The Firths of Forth and Tay answer to the Skagerrak and the entrance to the Baltic, while the comparatively unimportant harbours of north-east Scotland are most readily accessible from the Sogne and Hardanger fiords. In no place is our east coast difficult of access south of the Orkneys; but the most inviting spots in our early history were those which were at the heads of rivers, and led to a hinterland worthy of the sword of a conqueror. Such were 
the Thames, our best waterway; the Wash, giving access to the fertile midlands and the wheat-growing counties of Norfolk and Suffolk; the Humber, with broad-acred and beautiful Yorkshire behind it, and the Firths on either side Fife, "the beggar's mantle with a fringe of gold," backed by the natural fastnesses of Edinburgh and Stirling, fertile Strathmore and the central lowland of Scotland.

These were the coasts which attracted Roman, Angle, Saxon and Dane. It is generally accepted that the Jutes came from Jutland, the Angles from what is now Schleswig-Holstein, and the Saxons from Friesland. Hengist and Horsa are said to have landed at Ebbsfleet and conquered Kent. The names Sussex, Middlesex and Essex tell their own story, and bodies of Angles seized the lands now known as Norfolk and Suffolk. The nucleus of the invasions upon this side was 'Thanet. ${ }^{1}$ London being fortified and the Thames thus blocked, the Saxons sailed up the Colne and Chelmer and laid hold of Colchester and Maldon. Romish missionaries followed much the same lines. Farther north the Orwell and the Yare gave access to two tribes of the Angles.

The Danes showed a charming impartiality from the beginning. In 793 and 794 they sacked Lindisfarne and Jarrow, and not long afterwards the island of Sheppey. Charmouth in Dorset saw a victory by 1 Mackinder, Britain and the British Seas, p. 197 sqq. 
Egbert in 836, and another party landed in Cornwall. A new period began with the settlement in Thanet in 851 of a party of Northmen. From Tweed to Tyne not a church was left standing; Canterbury was sacked and London carried. Northumbria was soon wholly occupied, but Ethelred and Alfred managed to save Mercia. Iudeed, the culture of the former kingdom was well-nigh blotted out. Exeter, Essex, the Wirral Peninsula, Chester-nearly all England saw fierce struggles. Well it was indeed that such a man as Alfred arose to check the ruin of the whole country. The men who worked such destruction were the surplus population of Denmark and Scandinavia. The invasions of 987 began in Southampton and Thanet, and at Maldon in 991 the Essex fyrd was destroyed. The north-east coasts, too, again suffered severely. So it went on till Canute became undisputed king of all England. After these times descents upon our east coast became infrequent, and we need only note in passing the invasion of Louis in 1216, Henry of Lancaster's landing at Ravenspur in Yorkshire in 1399, "to secure his Duchy," and Edward IV's disembarkation in the same place in 1471, with the same professed motive. Ravenspur, on Spurn Point, has now disappeared owing to coast erosion.

7. Summary.-Two Classes of Invasion.-Throughout the events above referred to it will readily be seen that the invasions were of two kinds. The first were 
determined efforts in force, with an army ready-made and in a position to strike: the second were landings in remote parts of the kingdom with the idea of gathering strength after such landing. The various bodies of Danes, for instance, came prepared to conquer wherever they went, fully equipped and thoroughly primed. Perkin Warbeck, on the other hand, approached in a back-stairs way, hoping for the support that never came. So also Monmouth. These two cases are wonderfully similar. Neither man had any courage or initiative, and both foolishly attacked thrones that were secure. Henry of Lancaster, however, found that England's king was an absentee, and that the stars in their courses were fighting against Richard; and Edward IV owed his success to the treachery of Clarence, which gave him a thousand men, and to his own pluck in making a dash at London. The blow was successful, and Barnet and Tewkesbury followed. But it is poor work to land on an inhospitable shore on the off-chance of raising an army. 



\section{CHAPTER V}

\section{LONDON}

1. London-its Extent.-In a work of this character it is not necessary to be too strict in the use of the term London, and this title will be used loosely as a rule to include the vast centre of population astride the Thames where the great roads meet. The City of London, the portion under the jurisdiction of the Lord Mayor, is the comparatively small area between the Tower and Temple Bar. The County of London had a population of four and a half millions at the last census and covers 120 square miles. The jurisdiction of the Metropolitan Police (the mounted section) extends nearly twenty miles each way (e.g. to the North Downs), and includes a population of more than six millions of people. The Port of London has an extent of fifty miles from London Bridge to the Nore. Considering its size, "London" is quite remarkably healthya fact very largely due to the excellent drainage system which, in modern times, has always been very carefully tended.

2. Position-Initial considerations.-The study of the 
positions and causes of the greatness of the world's large cities is exceedingly interesting and comparatively simple. It must, however, be remembered that great phenomena are seldom explained by one cause, but that the reasons for such are to be found in the interaction of a number of causal factors. So it is with our metropolis. It is absurd to pin one's faith to some smart and pithy epigram, and to think that such will save us the trouble of working out the interaction of cause and effect, and of discriminating between the unessential and the vitally important. London is the largest, probably the greatest city in the world, the centre of our interests, the focus of our history; with no intrinsic beauty and next to no beauty spots, it is much courted and very dear to those who are familiar with it; it is a centre of commerce, of thought, of government, of Imperial power, of art, of industry; it possesses a most enlightened university and is the cradle and home of sorne of the world's most notable learned societies : it is the brain of the kingdom, the throbbing heart of the empire. Whence comes all this, and why have so many remarkable phenomena had their origin in this one place?

3. London's first existence.-The initial consideration is to explain the founding of a community at all on this spot. In the first place, the Thames estuary is the most accessible and wide-open passage-way from the opposite lands into the heart of the country. It is 
obvious that the River Thames must be a continental highway: where, then, can a town be built upon it, reasonably near the sea, for purposes of commerce and defence? The obvious place is where the stream can be conveniently bridged. In actual fact there was a fortified British camp on a low hill rising abruptly from the Thames, and narrowing the tidal lagoons to a breadth which made a ferry-afterwards London Bridge - possible.

The Romans used the crossing to connect their trunk roads, as also they did that at Westminster, two miles farther up. But the latter ford was abandoned in 1170, and London Bridge, then constructed, became the nucleus of the future city.

4. The main Highways.-Without differentiating between Roman and other roads (for the former are more than adequately described in every history text-book), we will now note the network of highways which nature permits to converge on the capital. For the essence of the position of the metropolis is its being the broad clay flat where roads and river meet. Northeastwards from the city Mile End Road and the Great Eastern Railway lead to Ilford, Romford, Chelmsford and the Eastern counties. Between Highgate and Enfield we have what ultimately becomes the Great North Road, as well as the Great Northern main line, leading in the latter case via Peterborough and Grantham to York, and thence, by Northallerton and Berwick 
along the east coast to Scotland. In a later chapter we shall see the vast importance of this great route. To the west of this we have Edgware Road and a variety of competing railway lines leading to the Midlands-the Great Central, the North-Western and the Midland. Oxford Street and the Great Western Railway run westward up the Thames to Oxford, and thence to Worcester. Piccadilly leads either to Maidenhead, ${ }^{1}$ Bath and Bristol (Great Western Railway) or viâ Staines to Basingstoke, Winchester and Southampton, a course followed largely by the London and South Western Railway. Continuing our circuit, we find less important roads and less favoured railways leading to the ports and watering-places of the south. From Surbiton one can travel through Guildford, Godalming and Petersfield to Portsmouth; through Croydon, Redhill and Crawley, Brighton is reached; and last, and most important in the reverse direction, the Kent Road leads through Greenwich, Dartford, Gravesend and Rochester to Canterbury and Dover.

5. Historical Geography of London:-First Phase. Julius Cæsar, landing on the Kentish coast, found his way on the south controlled by the then dense Wealden forest-a barrier which becomes more important in Saxon and Danish times. Colchester became for some time the headquarters of the British power under Cymbeline (Cunobelinus), owing to its position facing ${ }^{1}$ Mackinder op. cit., p. 256. 
Europe on a navigable waterway. But as the Romans established themselves in Britain, the obvious strategic importance of Londinium caused them to make it one of their strongholds. Their greatest road, afterwards called by the English Watling Street, led from the coast at Dover to this point, and thence to Chester. But with the English came a modification of conditions. The Saxon methods of warfare showed that these warriors had no liking for high-roads. They preferred by-paths. They disliked fortifications and they neglected towns. The walls of London fell into decay, and it was the neglect of this obvious stronghold that caused the Danes to make the Thames one of their chief lines of invasion and to penetrate whither they pleased. It was the wise foresight of Alfred which caused London to be occupied and fortified in 886. The king of Wessex had learned of his foes in previous years and had defeated them by their own methods; and now his military instinct urged upon him the imperative need of a real stronghold at this point.

6. Second Phase: The Conquest.-From this point onwards we find that London becomes the objective of all invaders, and we shall continue our study of its history from that standpoint. Olaf Tryggvason and Swegen made an unsuccessful descent on London in 994, and even Ethelred the Unready was able to keep them out, though he gave them money afterwards to get them away. Again, London held out bravely 
against Swegen twenty years later, when the rest of Wessex had fallen; and the city was only given up when the Dane had been crowned king at Bath. The importance of the place was enormously enhanced by the great struggle, and it was largely owing to London's faithfulness to the Saxon cause that Edmund Ironside made such a magnificent seven months' struggle against Canute. Indeed, the Danish king only succeeded to the rule of Wessex, Essex, East Anglia, and our present metropolis, when Edmund died.

The next important period was the attack by William the Conqueror. The Norman chose his landing-place well, and Pevensey Level first saw the invading host. Some slight heights to the north-east gave Harold his place of defence, but he was ruined by the immobility of his own force and the intelligent use of that fact by William, and the Duke had Sussex at his feet. He seized Romney and Dover to the East, and Winchester to the west, thus securing his position. He turned north-east from Dover to Canterbury, and with his way open to London, burnt Southwark. His idea now was to isolate London rather than storm it, and to give his entry as peaceable a character as possible. Accordingly, he marched to the south of the city for a considerable distance, crossed the Thames at Wallingford, wheeled round the back of the Chilterns and appeared at Berkhampstead. This cut 
off Edwin and Morkere, and there was no resource for the citizens but to submit as gracefully as possible. William was crowned at Westminster, and there only remained the task of securing for himself a divided country. Fortunately for him he was able to take each rising that occurred, in detail. In 1068 he found it necessary to take Exeter. This gave him the west. York was his next source of trouble, and he settled matters by wasting the beautiful vale from Humber to Tees. Early in 1070 he crossed the hills in frost and snow, and Chester fell. After that he had only Hereward's local rising to quell, and an uneventful march northwards to the Tay, and he was secure. Rufus had only the rising under Mowbray to suppress, which entailed a march to Newcastle, and Henry I's task consisted in subduing the power of Robert of Belesme at Bridgnorth and Shrewsbury.

The civil war in Stephen's reign presents one or two points of interest. Stephen having been taken at Lincoln, Matilda was recognized as queen, London submitting most reluctantly. She soon made her position untenable by her unstatesmanlike behaviour, and had to flee to Winchester. Stephen's queen, Matilda of Boulogne, had landed in Kent, and, after the exchange of the prisoner king for Robert of Gloucester, the war was ended by the siege of Oxford and the treaty of Wallingford-an interesting commentary on the events of 1066 . 
7. Third Phase: The Wars of the Roses.-WThe long period between Norman times and the reign of Henry VI is unbroken by any serious attempt upon the heart of the kingdom. Fighting in Wales, the grand struggles of Wallace and Bruce, and the misguided and futile Hundred Years' War were symptoms of the strength of a monarchy which could afford to be aggressive. Nor is it possible, when England is again seen convulsed with war, to gain any great scientific solace from the study of man's struggles. The Wars of the Roses were desultory and the fighting was often the outcome rather of the chance of the moment than of well-laid and consistent plans. Still, the belligerents always had London in view, and there are a few features of interest. The opening fight at St. Albans reminds us immediately of William I's shadowing of the capital from Berkharnpstead. York entered London immediately after. The battle of Bloreheath in Staffordshire was the defeat of an attempt from Westminster to seize the Earl of Salisbury. Margaret, finding the south against her, roused the north, and routed her enemies at Wakefield Green. This left the road to London open. At the head of a large and undisciplined force, Margaret met Warwick at St. Albans, and rescued Henry VI. But the city was saved nevertheless. Edward of York, who had defeated a force of Welshmen at Mortimer's Cross 
in Herefordshire, entered while the queen was talking about terms of capitulation, and the Lancastrians retreated north once more. The new king, Edward IV, pursued them into Yorkshire, drove in the rearguard at Ferrybridge near Pontefract, and came up with the main body a few miles further up the road to York, at Towton. Here, on Palm Sunday, March 29, 1461, the Lancastrians, whose position was turned by Norfolk, were utterly defeated in a blinding snowstorm. The war lingered on a little in Northumberland. The King-maker destroyed Alnwick, a town whose geographical position has brought it much woe, and Bamborough. The victory of Hedgeley Moor was afterwards gained a few miles away from the former town, and in May, 1464, the last desperate struggle of the Lancastrians ended in the rout of Hexham on the Tyne. In 1470, when Warwick turned against the king, Edward was drawn north by an unimportant rising, and Warwick landed at Dartmouth. Edward, returning, landed at Ravenspur (see p. 55), and made a dash at London. This was successful, and, to defend his capital, he gave battle to the king-maker twelve miles to the north, at Barnet. The fight took place in front of Hadley Wood, and a body of men issuing thence in a dense mist was mistaken by the Lancastrians for enemies. The confusion led to their utter rout. The fight at Tewkesbury has no direct reference to London. (See p. 49.) 
The battle of Bosworth was fought in August, 1485. Henry had landed at Milford Haven, and crossed the Severn at Shrewsbury. Thence he made for Nottingham, and, relying on the Stanleys, he attacked Richard III on Red Moor Plain, three miles southeast of Market Bosworth. The victory gave Henry the capital and the kingdom.

8. Fourth Phase: The Civil War.-In 1642, when war broke out between Charles I and his Parliament, the latter held London, while the former began by gathering men at Nottingham. Essex considerately allowed him time to gain strength, and Charles moved to Shrewsbury, increasing his forces as he went. Essex moved to Worcester, rather aimlessly, making no effort to find the king and fight him, and weakening himself by leaving garrisons in various towns. Charles made a dash for London by way of faithful Oxford. Essex hurried east, and forced him to turn and face him at Edgehill, a few miles north-west of Banbury. As the result of the fighting, Essex retreated to Warwick, and the king took Banbury Castle and gained Oxford, which he needed as his headquarters (unpleasantly near London), for the rest of the war. In the West. Riding of Yorkshire the Fairfaxes were cooped up by Newcastle, and the battle of Adwalton Moor, near Bradford, shut them up in Hull. In the west Royalist victories at Bradock Down and Stratton, near Bodmin and Bude respectively, and at Roundaway Down, south 
of Oxford and near Devizes, enabled the king to take the offensive. He intended Newcastle to march into Essex from the north and Hopton into Kent from the west, he himself holding the Earl of Essex in check; but Hull and Plymouth were not safe in Royalist hands, and he was forced to complete the subjugation of the west before making an attempt upon London. Bristol fell, but Gloucester held out, and Charles' plans were in consequence foiled. The relieving army was barred on its return by the king at Newbury, but won through successfully, and the tide began to turn in favour of the Roundheads. Cromwell, in the east, was not strong enough as yet to stand against the army commanded by Newcastle, nor to relieve Hull, but the cavalry in the invested town were sent by boat to Saltfleet in Lincolnshire, and joined Oliver and Manchester. The Cavaliers of Lincolnshire and some of Newcastle's troopers met them at Winceby, south of Gainsborough, and were heavily beaten. The siege of Hull, too, was raised.

In 1644, the arrival of the Scotch and the Parliamentarian attempts upon York led to the fight at Marston Moor, close to the ancient city. Meanwhile, Essex was hard pressed in the west, and lost most of his army at Lostwithiel, on the south Cornish coast. The northern Roundhead forces moved from Lincoln to save the remnant, and Manchester's half-heartedness allowed the king to get to Newbury before he was 
forced to fight. No definite result accrued from the very much mismanaged battle which followed. The next campaign, that of 1645 , found Charles at Oxford and Rupert at Worcester. Cromwell, now in supreme command, routed some cavalry that opposed him at Islip, near Oxford, and at Bletchington and Faringdon, a few miles off, he gained further successes. This seriously hindered co-operation with Rupert. A futile siege of Oxford by Fairfax followed, and Charles and his nephew marched about the Midlands, storming and sacking Leicester. At last military considerations were allowed by Parliament to outweigh political, and the Royalists were met at Naseby, near Northampton. Here Charles' hopes were completely ruined. He himself became practically a fugitive, and the south and west, after some fighting at Basing and Langport, fell into the hands of the Puritans. Oxford capitulated on June 24, 1646, and the war was over. The rest of the struggle, ended in 1660 by the restoration of the monarchy, belongs to Scotland rather than to Metropolitan England, and will be found in Chapter VII.

9. Subsequent History.-The Restoration marked an interlude in the civil struggle, and an epoch in its methods. A wild orgy of rejoicing at the re-establishment of the monarchy was followed by a very pronounced cooling down of royalist enthusiasm. Stringent and futile recusancy laws, a naval war which, though 


$$
V
$$

. . . .
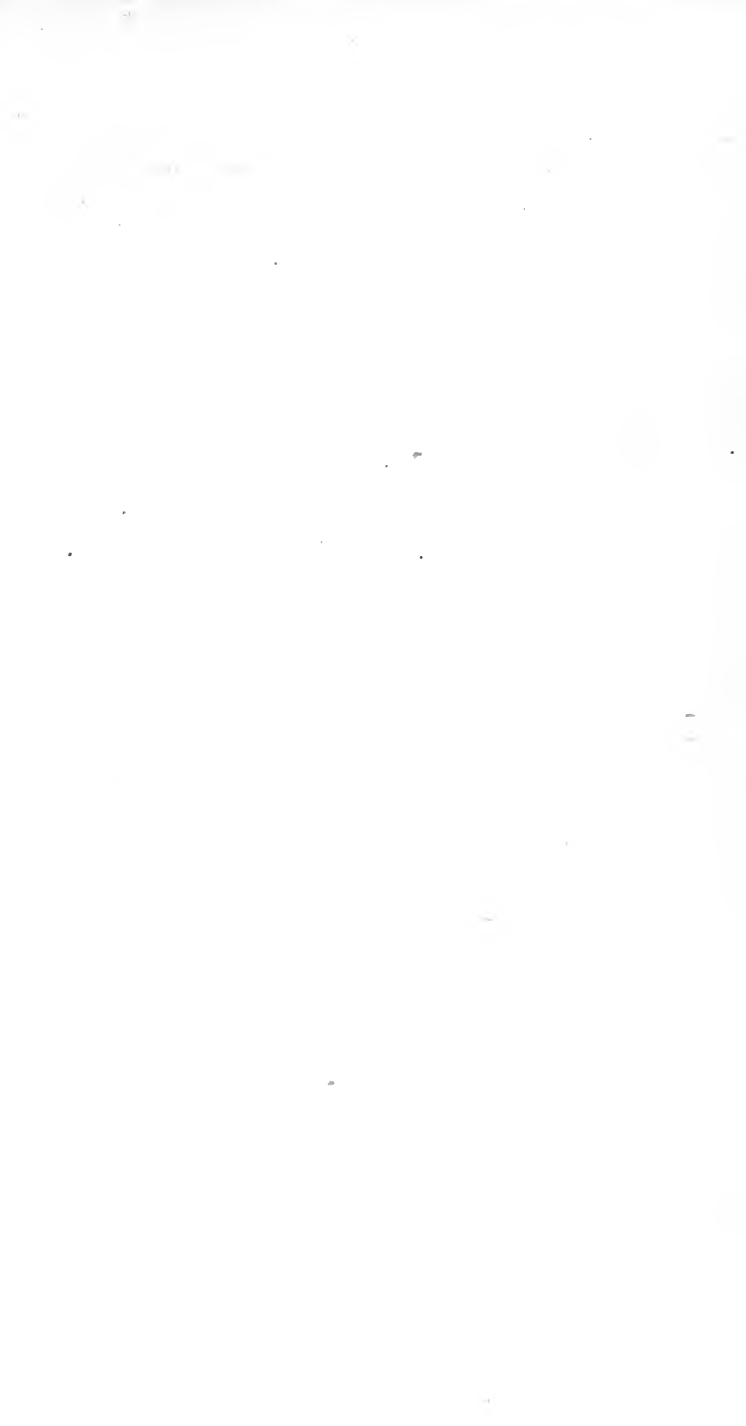

not wholly unsuccessful, brought insult and disgrace upon us (see par. 11, Chapter X), and a dishonourable liaison with Louis XIV in 1670, did much harm; while James II's conduct was so brilliantly fatuous that all combined against him, and William of Orange was called over. Monmouth's invasion has been discussed in Chapter IV, and concerning William's, it is only necessary to add here that it succeeded in reaching our shores at all owing to a momentous decision of Louis XIV. That monarch had to decide whether he would send a fleet to crush William, or allow England to be convulsed with civil war, and so ensure her helpless neutrality in the European struggle. A determined French fleet, had he only known it, would at this precise-juncture have altered the whole current of English, and, in consequence, world-wide history. There is no doubt of our naval unpreparedness in $1688 .^{1}$ Louis turned his attention in the wrong direction. He moved his armies to the Rhine, and left to herself England, the power which twice subsequently dealt a mortal blow at France when it seemed as if nothing human could stop the aggrandisement of that power. So it is that our historico-geographical study of London practically ceases with the accession of William III. The history of England now becomes one of almost uninterrupted expansion. As a rule, we strike before we are struck. The British Empire springs into 1 Mahan, Sea Power and History, p. 180, sqq. 
existence. Henceforward, blows aimed at us are never struck home. James II descends upon Ireland, but gets no farther (Chapter VIII). The Young Pretender hesitatingly reaches Derby, and soon retreats (Chapter VII). Napoleon assembles a vast force at Boulogne; but that is all. Blenheim, Trafalgar, Waterloo-so far afield is it that England is able to wield the sword in her own defence.

The history of London, accordingly, becomes a history of continuous and well-sustained progress. The course of events is no longer inward, but outward. England ceases to be insular, and becomes Imperial. 


\section{CHAPTER VI}

\section{WALES AND ENGLAND}

[The student is recommended to use Bartholomew's Touring Atlas of the British Isles (Newnes) in following the next three chapters.]

1. Structure of Wales. - We have already seen (Chapter III) that the centre of England is occupied by a plain of Triassic ("New Red Sandstone") strata. This is edged in the south-east by the great Oolitic escarpment running from Lyme Regis to the Tees by way of the Cotswolds and Lincoln. In the north there gradually rises the mass of Carboniferous strata forming the Pennines, and on either side of these the level land continues to the sea. The Permian passes under the ancient mountains of the Lake District (reappearing round Carlisle and Dumfries), and skirts the great Northumberland coal-field. To the west lies Wales, a peninsula, and like most peninsulas, mountainous. In structure, it entirely differs from the plain which gives access to it. Leading from Hereford to the south is a wedge of Old Red Sandstone running into the sea at Milford Haven and overlain by the coal-measures in 
Glamorgan. To the north and west lie great masses of Silurian rock, penetrated in Carnarvon and Merioneth by intrusive igneous masses which form some of the highest summits, such as Cader Idris and Snowdon, ${ }^{1}$ mountains which have survived the ravages of time because of their exceeding hardness. The massive slates which predominate in most of Wales reach to the western sea, and in many places form noble cliffs.

The occupations of the inhabitants, even in these days of mobility - mobility of capital, of labour, of raw material, of energy-reflect in no small measure the character of the terrain. The wonderful mining industries of the south, the quarries of the north, whence are obtained huge quantities of slate and road-metal, and the sheep-rearing and flannel production of the centre, are all the direct outcome of the structure of the land. But what of the Welsh character?

2. Geography and Character.-The main purpose of this book is to show how physical conditions have affected history. A subsidiary object is to warn the student against allowing himself to be drawn into too broad generalizations. Mountains-love of liberty-imagination; such is the line of thought that is always advanced. In the same way we often hear the suggestion, nearness to the sea-love of liberty-colonizing ability-worldwide empire. Both processes of reasoning have more than an element of truth in them. But is the rule

1 See Avebury, Scenery of England, pp. 240 to 245. 
universal ? History tells us of the grand and successful struggles of Switzerland against overwhelming odds. But has highland Bohemia, or the lofty Iberian Peninsula, or mountainous Bavaria the same tale to tell? We islanders often point to the plains of Russia with holy horror, and speak of the sad fate of lowland or inland peoples, bereft of liberty and even the power of successfully asserting the principles of liberty. But we forget ultra-lowland Holland. But it was maritime Holland that beat off Spain, it will be answered. Not maritime Holland, we think, but Protestant Holland. The thumbscrew and the stake conquered Spain. And do these same reasoning processes apply to Prussia? Hardly. It was the organizing genius of Frederick William I, backed up by the indomitable courage of his son, that made the modern German Empire possible. Differences in religion have made history; royal marriages have made history; organization (prosaic but well-nigh irresistible), or its lack, has made history; individuals have made history. Do not let us lose sight of any of these when we are studying the effects of geography.

3. Welsh Geography and the Welsh Character.-Mr. Owen Edwards, ${ }^{1}$ in his wholly delightful book upon Wales, points out some of the general principles which we have noticed. "A glance at the map of Wales shows that it is difficult to conquer. . . . The Welsh,

1. The Story of the Nations: Wales. 
at the approach of the invader, could drive their flocks into their hill fastnesses; and, safe among the storms and the rocks or forests, could wait till the enemy had been sent from the banks of the Wye and the sandybottomed Severn, bootless home and weather-beaten back. The same glance," he continues, "will show us that Wales is ill-adapted for union. Its valleys are separated from each other by high and pathless mountains; they open out on the sea of the west or on the plain of the east. There is no central point upon which paths and roads could converge. Wales never had a capital." In short, the main characteristic of the mountain people is clannishness. This word is generally used in a rather bad sense; but no such construction need be put upon it. Wales is a country physically separate. The Welshman is also distinctive. $\mathrm{He}$ is imaginative, he is outwardly religious, tremendously excitable, open to more than a suspicion of instability, fond of Welsh poetry and passionately fond of Welsh music. "The wild and rugged outlines of the mountains are mirrored as intense but broken purposes in the Welshman's character, always forming great ideals, but lacking in the steady perseverance of the people of the plain." $\mathrm{He}$ is, in fact, the child of his surroundings, and he carries the imagery of them wherever he goes.

In reading the paragraphs which follow, the student must have carefully in view the following important geographical features:- 
i. The Midland Gate, leading from the heart of England viâ Cheshire to the narrow coastal plain of North Wales; Chester, where routes narrow down to the lowland of Flint and pass over the Clwyd at Rhuddlan, the Conway near Deganwy and at Conway, and leading thence either up the Conway to the back of Snowdon, the citadel of Welsh independence, or along the coast to Menai and Môn.

ii. The courses of the Severn and the Wye, with Shrewsbury, Montgomery and Hereford as points from which to attack the interior, or raid England.

iii. The lower Severn, behind which screen were made many sets of preparations for invasion of English territory.

iv. The South Wales lowland, leading to Pembrokeshire, and like i., eventually to and from Ireland.

v. The coastal plain of the west, a fairly easy route, viâ Aberystwyth, from Carnarvon to the remote English territory of Pembroke.

These must be understood to be "between the lines" of the succeeding part of this chapter.

\section{Early History.-A glance at Plate II will convey} a strong presumption that the most likely course of entry into Wales is that from England. Seaward, foreigners were far more likely to pass into the English Channel than to enter the Severn estuary or the Irish Sea. The tidal bore in the narrows of the former, too, may have given invaders pause, while at first sight the Welsh coast is very difficult of access. Along the south, however, an enterprising fleet could land without serious 
trouble, and it is here, possibly, that the Iberians, moving from Mediterranean shores, may have first had a footing. If appearance goes for much, the land of the Silures (the south-east), especially Gwent, still preserves the dark, short, long-skulled type which is claimed to be the Iberian. The Celts from northern Europe, tall, fair and blue-eyed, appear to have clashed with the Iberians and overcome them. Their bronze and iron weapons were too good for the stone implements of their predecessors. In early and medieval times, too, there were certainly two classes, free tribesmen and subject serfs. This points in no very inconclusive way to the two races, the one conquering, the other conquered and sharing in the division of the land, but having no kinship rights. Before Roman times the Decagni ruled in Gwynedd, the rugged Snowdon country. The Ordovices held Powys, the Berwyn district. Round Plinlimmon and along the coastal Ceredigion (Cardigan) to Dyved (Pembroke) lived the Demetae, and the Silures, as has been already mentioned, inhabited the Black Mountain district, Morgannwg and Gwent. To this day the four districts are kept in remembrance by the four dioceses of Bangor, St. Asaph, St. David's, and Llandaff.

5. The Romans.-The Romans first came into contact with the Britons of Kent in the year 55 B.c. Twelve years later Aulus Plautius began the conquest of the midland plain. Caratacus, the successor, in opposition 
to the invaders, of Cymbeline, after fighting numberless battles, was compelled to retire to the domains of the Silures. Ostorius Scapula clinched the conquest of the east by building the castle of Uriconium (Wroxeter) near Shrewsbury, just to the west of the Wrekin, and Glevum or Gloucester, and so threatened Wales also. The Decagni of the north he broke through without serious trouble, and after quelling a "rebellion" in the midlands he turned against the Silures. These he finally met on the slopes of Berwyn and defeated decisively, taking Caratacus captive. A guerilla warfare was kept up by the Britons in spite of their misfortune, and for many years the Silures maintained a bitter struggle. Suetonius Paulinus, like his predecessor, won through north-westwards to the sea, and then crossed the Menai Straits and wiped out the army of Môn (Anglesey). Not until the year 78 was Wales conquered thoroughly, and Carnarvon and Carmarthen marked the limits of the empire. Then the familiar story of Roman peaceful occupation began; roads were made, the resources of the country developed, agriculture flourished, and even mining was begun. Christianity, too, found its way among the Cymry.

6. The Anglo-Saxon and Danish Migrations.-As is well known, Rome grew weaker and weaker, and withdrew her legions from our islands. The Angles ‘and Saxons found what is now England a fairly easy prey; but the resistance was much more stubborn in the west, 
owing to the remoteness of the country and the consequent weakness of the invaders, and to the ease with which the land was defended. ${ }^{1}$ The family of Cunedda, driven southwards from the wall, took refuge in Deganwy, nearly opposite Conway. Maelgwn meanwhile united the west under his rule. About $550 \mathrm{Ida}$ of Bamborough and the Saxons of Salisbury Plain were moving westwards. In 577 Ceawlin won the important victory of Deorham in the Severn Valley. ${ }^{1}$ The West Saxons reached the sea, and Cornwall fell away from Wales. Then came the Angles in the north. The battle of Chester, ${ }^{2}$ about 613, did for Ethelfrith what Deorham had done for the Saxons, and Wales was completely cut off from Strathclyde. The rise of Mercia brought further trouble, and Offa extended his rule over Worcester, Gloucester, Hereford and Shrewsbury, largely because Conan and Howel, the sons of Rhodri Molwynog, spent their energies in fighting each other instead of the common foe. So Dyved was entered by Cenwulf, and Deganwy was burnt. Soon the Northmen arrived, and they came from the north and the west, by sea. Rhodri, a contemporary of Alfred, tried to organize his forces against the invader, but was driven out of the country into Ireland. When Rhodri died the Welsh allied with Wessex, and drove out the Danes who were harrying the valley of the Usk. Comparative peace followed for many years, but the

1 Paragraph 3, iii.

${ }^{2}$ Paragraph 3, i. 
Northmen came again and burnt St. David's to the ground, and the Mercians ravaged the valleys of Dee and upper Severn. Griffith ap Llewellyn, however, beat the Mercians severely at Rhyd y Groes, high up the Severn, in 1039, and at Pencader he won a victory which gave him Ceredigion. In 1044 the mouth of the Towy saw him win possession of the south. Thus was Wales for a time consolidated; but it soon came into collision with Harold of Wessex. The latter was unable, with his heavy-armed troops, to come to blows. He made Gloucester his base and then made a sudden descent upon Griffith at Rhuddlan, in the Vale of Clwyd, nearly capturing him. Next he took two armies, one along the north coast and another along the south, and after four months of ravaging the Cymry sent Griffith's head to Harold as a peace-offering. Soon after, Harold himself was killed at Hastings.

7. The Norman Conquest.-William of Normandy had no light task left him when the battle of Senlac was won. Mercia and Northumbria had to be pitilessly harried before they would submit, and the capture of Chester completed the conquest of England. Hugo the Wolf was placed by William in the castle. Thence conquests were pushed along the coast to Conway and Deganwy. At Shrewsbury the Conqueror placed Roger of Montgomery, a man of pre-eminent ability, who served his master well, and incidentally himself too, in his new quarters. William Fitz Osbern was placed in 
Hereford, which commands the Wye and the heart of the comparatively low country between Plinlimmon and the Black Mountains. Slowly the conquest was pushed forward from these nuclear fortresses. In the Vale of Clwyd rose the castle of Rhuddlan, threatening Gwynedd. Montgomery was built, making the men of Powys tremble.

Then a claimant for the Welsh kingship appeared in Griffith ap Conan, who took possession of Snowdon, and drove the Norman knight of Rhuddlan back to his castle. However, as was customary, dissension arose in the Welsh ranks, Griffith became a fugitive, and the Normans advanced to the Conway. Landing again in the south, Griffith gained strength from the alliance of Rees ap Tudor, and met the men of Powys, Gwent and Morgannwg in the south of Ceredigion in 1079. The decisive battle of Mynydd Carn decided that the former exile was to lead Wales against the Normans. But Rees was killed at Brecon, Griffith was cast into prison at Chester, and the Normans pressed on into Môn and built a castle there. From Shrewsbury Hugh, son of Roger of Montgomery, travelled from the Severn into Ceredigion and down the Teifi, building a castle close to the present Cardigan. Arnulf, brother to Hugh, crossed into Dyved and built Pembroke. Another Norman, Martin of Tours, came by sea and built Newport. Fitz Hamon, too, from Gloucester, overran and "settled" Gwent and Morgannwg. "By about. 1094 a line of 
Norman castles extended along the whole length of the south-east, from Chepstow to Pembroke. The only parts of Wales not conquered were the districts round Aberffraw in Gwynedd, and around Dynevor in the Vale of. Towy-the seats of the power of the two branches of the royal line of Maelgwn." 1 But Griffith ap Conan reappeared, none can tell how with certainty, and stormed the Norman stronghold Aberlleiniog in Môn-a very great feat. He passed on by sea to the Great Orme, and made a successful descent upon Rhuddlan, killing Robert and carrying away his head in triumph. Into Powys, too, the Welsh revival spread, even Montgomery being taken in 1095, and nearly all Dyved passed again into the hands of the Welsh. William Rufus came and pierced to Snowdon, but more than one expedition failed to do more than just secure to the Normans the ground on which they stood. After many vicissitudes it was arranged by 1099 that the Normans were to have the eastern and southern slopes of the mountains, and the Welsh the west. Robert of Belesme held the land from Shrewsbury to Pembroke, and desired to establish a kingdom of the west in defiance of Henry I, but the English king decided otherwise, captured him and sent him into exile. Another expedition by Henry into Wales failed to crush the patriots, and in 1137 Griffith ap Conan, a leader truly great and wonderfully constant, died.

1 O. M. Edwards, Wales, p. 60. 
8. Henry II.-The great expedition of Henry II has too many features illustrative of our subject to be passed over, though historically it is of slight importance. It may be regarded as a suitable prelude to consideration of the career of Llewelyn the Great. Owen Gwynedd is the central Welsh figure, and the proceedings are characteristic-a strong English force, a small Welsh one, a natural disinclination on the part of the latter to come to blows, semi-starvation of the aggressors, retreat and compromise. (Compare Paragraph 5 of Chapter VII.) Henry tried to isolate Owen in Snowdon and besiege him there. An army was sent to Rhuddlan and a fleet to Môn. Both were badly cut up, and Henry made peace for a time. Again he came in 1157, and this time he chose Oswestry as his base, making for the Ceiriog valley and Corwen. Owen disputed every inch of the way, and when Henry reached the exposed Berwyn mountains he was forced to turn back. Peace was made, and the energies of many of the more turbulent spirits were directed soon afterwards by Strongbow upon unfortunate Ireland.

9. Llewelyn the Great.-The early part of the career of the great Llewelyn is merely a retelling of the old story. An invasion by the king from Chester, a removal of the flocks to the mountains, eggs selling for a penny halfpenny apiece, John's retreat, his return, the burning of Bangor, and peace at the price of twenty thousand Welsh cattle. An alliance between the Pope 
and the Welsh prince, with the support of the barons, brought Llewelyn some gain in 1215 at the signing of Magna Charta. In Henry III's time William Marshall was the great opponent of the Welsh prince, in Pembroke. The struggle went on for many years, and the English chieftain could easily keep his own possessions; but no Welshman dared appeal to him for help against Llewelyn, for retribution was swift and sure. So peace was made and consolidated, and, when the great prince died in 1240, all seemed fair-Wales in alliance with the King of England, and allegiance sworn by the chieftains of the Cymry to Davydd, the unwarlike son of Llewelyn.

10. The Edwardian Conquest.-With the events that led to the invasion by Edward I we are not concerned here. Suffice it to say that on the death of Henry III Llewelyn, prince of Wales, refused to take the oath of fealty, and the last struggle began between an obstinate defender and a mercilessly determined conqueror. In 1277 the king's army advanced in four divisions. The king took the traditional Chester-Rhuddlan route. Roger Mortimer advanced through Shrewsbury and Montgomery, the Earl of Hereford made for Brecon, and Edmund of Lancaster led his men from Carmarthen against Deheubarth (north of the Black Mountains) and Ceredigion. South Wales was soon reduced, and the king's brother built the castle, the remnants of which are still conspicuous at Aberystwyth, to confine 
Llewelyn to the north-west. A fleet devastated the crops of Môn, and Llewelyn was compelled by the certainty of famine to sign the treaty of Rhuddlan. The terms of the settlement are given in substance in Chapter IX. Llewelyn was deprived of his title and ringed round with rivals. The end, however, was not yet. In five years' time rebellion had broken out. Aberystwyth Castle was taken, and Hawarden also fell. Edward raised another army and again marched over the familiar ground of the north. Flint and Rhuddlan were relieved: Llewelyn lay beyond Conway. Penmaen Mawr was attacked by hired and trained mountaineers, and a turning movement on a grand scale was developed from Môn. A large force crossed, but was driven back headlong into the Menai. Winter came, and during its course Llewelyn made southwards through Ceredigion and the Vale of Towy and into the Builth neighbourhood. There he fell to a Cheshire man-at-arms in a chance encounter. Resistance to Edward forthwith collapsed : Davydd was taken and given a traitor's doom like Wallace, the Statute of Rhuddlan was enacted, and Edward of Carnarvon became the first English Prince of Wales.

11. Wales after the Conquest.-Edward II was popular in Wales, for he was born there; and the Black Prince took several thousand Welsh archers with him to France. The arrow which revolutionized medieval warfare was introduced into England from Wales and 
worked amazing wonders. Many Welshmen, too, fought in France against the Black Prince. Owen of Wales planned two naval expeditions from the Continent to his native country; but they came to nothing, through no fault of his. He attacked Guernsey, and after many adventures was assassinated. Later, $\mathrm{O}$ wen Glendower arose and made a vain attempt to procure the independence of his country; but his death in 1415, and Henry's victories over his enemies at Shrewsbury in 1403 and Bramham Moor in Yorkshire in 1408, made the patriot's dream impossible of fulfilment. The Wars of the Roses did not leave the western land unscathed, for after many of the Cymry had fallen in previous engagements far from home, the two parties definitely fought each other at Mortimer's Cross in 1461. This engagement, with Bloreheath and Ludford (on the Teme) left the marches badly scathed by war. Archers of Gwynedd fell in scores on the fatal day of Towton, and Harlech long held out for Lancaster. Henry of Richmond landed in South Wales, followed the Teivy, passed Machynlleth and made for the Severn, taking Welshpool on his way. Shrewsbury opened its gates to him, the Stanleys of North Wales joined him, and by Lichfield, Tamworth and Stafford he travelled to Bosworth, to luckily survive on the field of battle, and rule England afterwards.

One episode remains to be touched upon lightly, the 
Civil War. In 1643 the king's armies from Cornwall, Wales and the north were to unite and march on London; but Gloucester held the South Welsh back, and Essex occupied Monmouth and Chepstow. Chester was Royalist, and the gateway from Ireland to boot, but a battle near Nantwich proved disastrous to the king's Irish forces. Oswestry fell soon afterwards, and Montgomeryshire was overrun by the Parliamentary troops. In 1645, however, the Royalists took Haverfordwest, compelled the enemy to burn Cardigan, and occupied all Pembrokeshire with the exception of Tenby and Pembroke. Chester, however, remained closely invested by the Roundheads, and Naseby (where the bulk of Charles' infantry was Welsh) proved a crushing blow. Bristol was stormed, and an unsuccessful attempt to relieve Chester was foiled at Rowton Heath. Gradually the whole of the country fell into Cromwell's power, and the First Civil War was over with the surrender of Pembroke.

At this point the historical geography of Wales ceases. The interests of the country have become indissolubly bound up with those of the Empire. As Welshmen did their duty in the days of their independence, so now they do their duty towards the great unity to which they so honourably belong.

12. Summary.-It will be readily seen that history has moved along the routes indicated in Par. 3. The Romans and the Normans used the Severn, notably at 


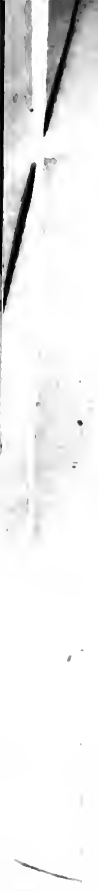

$\therefore$

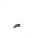



Shrewsbury, as their base, making strongholds at important strategical points. The Welsh, in the reigns of Stephen, of John, of Edward I, of Henry IV (especially), and of Edward IV, used the line of the Severn as a screen for warlike preparations. The northern coastal plain again and again saw large English forces pass on to temporary conquest westwards, opposed at the crossings of Clwyd and Conway; and the easily accessible southern lowland was particularly used by William I, Henry II and the leaders on either side in the Civil War of 1643. 


\section{CHAPTER VII}

\section{SCOTLAND AND ENGLAND}

1. Character of Scottish History.-It is almost impossible to separate the history of Scotland from that of England. There never has been any great natural barrier between the two realms, and as a consequence mutual relations have resulted in attempts by the richer southern kingdom to absorb the northern, and in a bitter and heroic struggle for independence on the part of the badly organized and all too disunited Scots - the whole resulting in a characteristic British compromise. In few countries has geography had a more profound bearing upon history than in Scotland. In the south no formidable physical feature tells the traveller that he is passing into another realm, or obstructs his way thither. Hence we find a large area of debatable land existing before the eleventh century. The west coast route through it leads from the Midland Gate past Preston, Lancaster, Carlisle, and through one of the dales of Dumfries to the Clyde. The east coast route passes through the Vale of York to Northallerton, Durham, Newcastle, Morpeth, Alnwick, 
Berwick, Dunbar and Edinburgh, and there is no difficulty in the route in any part. It extends unbroken from Edinburgh to Linlithgow, Falkirk and Stirling. Thence it leads by Dunblane, ruund the south-western end of the Ochils to Auchterarder and Perth. Traversing Strathmore, it passes by Coupar Angus to Forfar, Brechin and Montrose, and so to Stonehaven, crossing the Dee at Aberdeen. The coastal plain, rather narrow here, now broadens out, and the Deveron Valley can easily be struck at Turriff, whence Banff is reached. An alternative road viâ Huntly to Portsoy has its advantages, though it is steeper. The way is very plain from Nairn to Inverness. The extreme north-east has derived its humble history from the eastern sea rather than from the southern land, as it is sufficiently remote to dwell in peace, and sufficiently poor to offer no rich harvest to the invader.

Most of the history of relations between England and Scotland has hinged on these two routes, the east and west-more especially the east. They unite on the Rift Valley between Glasgow and Edinburgh. Early history, the history of times when men's topographical knowledge was slight, favours the east coast route; later events moved almost equally along the west. Wallace fought at Falkirk: Cromwell at Preston as well as Dunbar.

2. Early 0ccupations.-It seems clear that the northern portion of our island was once inhabited by Picts 
or Caledonians, except the southern uplands, which were in the hands of Britons. These last were absorbed by the Romans. They, in their turn, were too far from their base and were not sufficiently keen to attempt conquest north of the Rift Valley. When Britain was left to its fate, Angles seized the east coast from Tees to Forth (see Plate II). The east coast, with Bamborough as a centre, 1 then, became the kingdom of Bernicia (see Chapter IX). British Strathclyde appears to have had Dumbarton (Alcluyd) for its capital and northern limit, while Galloway, owing to its peninsular and remote position (see Plate V), remained Pictish. This last is an interesting commentary on the wellknown fact that the opposite corner of Ireland, County Down (Plate VI), long remained in the hands of the Picts. Others passed from Ireland, under the name of Scots, and tenanted Argyll. Then came the Northmen (Plate II), who occupied the islands from the Shetlands and Orkneys to the Isle of Man. They gained, too, from the Orkneys, a fairly permanent hold upon Caithness, which is very open on the north-east. Further history is illustrated by the spread of Christianity from Ireland to Iona and across to Lindisfarne, and by the spread of the English language along the eastern coastal plain northwards through Strathmore. If possible, the study of this point should be completed

1 See Scotland in the Oxford Historical Atlas, and Fig. 106 in Mackinder, op. cit. 
by careful reference to the language maps at the beginning of Bartholomew's Atlas of Scotland. ${ }^{1}$ The spread of the blue colouring (English) north-westwards at the expense of the red (Gaelic) is most instructive, and shows in a graphic manner the influence of geography upon one aspect of history even at the present day.

3. Scotland and England: the beginning.-History begins to emerge from the fogs of fable and tradition with the well-known story of Macbeth, who died during the reign of Edward the Confessor. The relations between England and Scotland had their origin in the Norman Conquest. Malcolm Canmore married Margaret, sister of Edgar Atheling, in 1068, and thought it his duty in consequence to show his sympathy with the Saxon cause. Not being strong enough to wage successful war upon William the Conqueror, he contented himself with making deep and bloody inroads into northern England, and brought away numbers of Saxon captives-thus introducing a much-needed civilizing element into the Scots life of the time. Many discontented Normans, too, repaired to Malcolm's court. He gave them grants of land, and most of the Scots nobility are of Norman descent. Malcolm gained a firm hold upon Lothian and penetrated Cumberland, but met his doom at Alnwick while attempting the conquest of Northumberland.

The usurpation of Stephen in $\mathbf{1 1 3 5}$ led to a raid by

? Plate IX, Notịce Glen More and Glen Dochart. 
King David in favour of his niece, and, incidentally, for his own territorial aggrandizement. The well-known Battle of the Standard took place at Cuton Moor, near Northallerton. The victory, gained by the northern barons at the instigation of Archbishop Thurstan, saved England from an invasion which would have gone on unchecked at least as far south as the Humber. Matters were now fairly quiet until the time of William the Lion. He made an incursion into Northumberland, and the Yorkshire barons, taking the bull by the horns, made for him by forced marches, capturing him at Alnwick. Thus did history repeat itself owing to geography. 'This capture, and the restoration of the king by Richard I for 10,000 marks, had far-reaching effects. A formidable invasion by Haco of Norway is worthy of passing notice. He came down the west coast and descended finally upon the Firth of Clyde, took Arran and Bute, and fought a land-battle at Largs, by Great Cumbrae Island. Here he was heavily defeated by Alexander III. The Northmen lost to Scotland all the western islands, including the Isle of Man, and thus an interesting chapter was closed. The Orkneys and Shetlands were ceded as dowry to James III in 1470 .

4. Edward I.-The most dramatic period of Scottish history begins with the death of Margaret, Maid of Norway. The interregnum which followed is conspicuous for the interference of Edward I of Eugland. 
He declared John Baliol, Lord of Galloway, to be king in 1292, and claimed Berwick, Roxburgh and Jedburgh (giving him full control of the Tweed Valley) as the price of his beneficent interest in northern affairs. Baliol made a show of resistance, but was crushed at Dunbar. So was Scotland tempurarily made a province of England. Events soon brought into the field William Wallace, one of the many who were suffering from the harshness of English rule. Assembling a considerable force, he awaited the approach of the English governor John de Warenne at a bridge over the Forth near Stırling (Cambuskenneth). The defeat of the English left the way open into Northumberland, which Wallace harried, and isolated the English strongholds, many of which fell. Edward I replied in person by hurrying over from Flanders, collecting a large force, and advancing, as before, up the east coast. He reached Falkirk without serious opposition. This town is in a most important position. Berwick and Dunbar once passed, and Edinburgh in the hands of the invader, an engagement must be fought by the invaded to guard the Rift Valley to the west as well as the road to Stirling. Notice carefully the position of these places on Plate V. It is obvious that the Scots were not strong in numbers as compared with their enemies, or they would never have waited, in 1297, 1298 and 1314, for the enemy to attack them in, so to speak, their last ditch. The defeat of Falkirk was, therefore, final as far as this campaign 
was concerned, though Wallace was not himself captured for seven years.

The rise of Bruce forms the next noteworthy incident in our brief survey. He was crowned in 1306, and less than three months later he was attacked by the Earl of Pembroke at Methven, near Perth, the whole of southeastern Scotland being evidently in English hands. Defeated, he fled into the Highlands, and after many narrow escapes, succeeded in doubling back through Lorne into Ayrshire, where he was nearly taken at Dalry. His wife he left at Kildrummie on the upper Don, well out of the way. This place was nevertheless taken, and Nigel Bruce killed, while Robert was in Ireland. Thence he crossed to Arran and finally landed at Turnberry, about fifteen miles south of Ayr. He was now near his own earldom of Carrick and the friendly land of Douglas, and slowly began to gather strength for the struggle which must come. Edward I raised another army and marched northwards. The east being secure as far, probably, as Aberdeen, he took the western and more difficult road via Carlisle, so as to strike at the centre of disaffection, to the north of Solway Firth. His death stopped the invasion, and the supineness of his son gave the Scots a golden opportunity which they were not slow to seize. Edward only marched as far as Cumnock, a few miles due east of Ayr, and then went back. The "Good" Lord James of Douglas retook the castle which bears his name, Sir 
Thomas Randolph surprised Edinburgh Castle, Linlithgow was taken by the celebrated trick of the haycart which prevented the portcullis from falling, and Roxburgh, near the confluence of Teviot and Tweed, also fell a prey to the Black Douglas. Stirling alone remained, blockaded by Edward Bruce, and the English king at last stirred. It was necessary that Stirling should be relieved immediately, so Bruce was able to choose his ground near the castle, and the Battle of Bannockburn followed. 1 Edward showed unwonted energy in his ride to Dunbar, and then got away by boat. The Scots were able, after their wonderful victory, to lay waste the country as far south as York.

5. The Border Struggles.-The opening of Edward III's reign was signalized by an invasion under Douglas and Randolph, when the mobility of the northerners proved very expensive to the English. The armies watched each other across the Wear, and on one occasion the Scots are reputed to have got away by making a road across "Shorn Moss," near that river. The Treaty of Northampton followed, on mutually satisfactory terms. Some dispossessed English lords, however, with Edward Baliol at their head, as soon as Randolph (then regent) had died, made their way by boat to Fife and gained a surprisingly complete victory

1 For the site of the battle, see Geikie, Scenery of Scotland, p. 432. For Scots and English support for Bruce, see Andrew Lang's History of Scotland, vol. i., p. 495, Appendix C. 
over Mar at Dupplin Moor, near Perth. Baliol assumed the crown of Scotland at Scone, a few miles farther north, and gave up Berwick to Edward III. The successors to Bruce's companions could not allow this, and they marched to save Berwick. Halidon Hill, just outside the town, was the scene of operations, and the English archers won the day. A noteworthy sequel was the gallant and successful defence of Dunbar by Black Agnes, Countess of March. When the Hundred Years' War began in France, Edward was unable to pay Scotland full attention. Edinburgh, Perth, and other important places were won back. In 1346 David II invaded England, and passed the Tyne, but he was defeated and taken close to Durham at the battle of Neville's Cross. The Scow were not crushed by any means, for the Douglases won back their territory and drove the English out of Ettrick Forest. Indeed, the east was not safe, for the spring of 1355 was signalized by the harrying by Edward of East Lothian (Burnt Candlemas). War was more or less chronic at this period. In 1385 a fine English army marched up this same route, while the Scots slipped into Cumberland and made merry there. The latter were always prudent enough to avoid decisive engagements with the superior English forces; but desperate combats on a smaller scale were numerous. The fight of Otterburn, in 1388, between the Percies and the Douglases, who had penetrated from Carlisle to Newcastle, is a good 
example of this. The latter retreated, as soon as they thought prudent, up the Tyne and then along the Rede, a left-bank tributary. They were surprised about twenty miles from the border, but beat off the English. The death of Douglas and the capture of two of the Percies are facts which go to show the determined nature of the encounter. It is well to observe that Hexham, a notable name in the Wars of the Roses, is on the same road. Hedgeley Moor is farther north, near Alnwick; and these two places were the scene of the last stand of the remnants of the Lancastrian army. Again, in 1402, the Douglases invaded England, and took great spoil. Hotspur waylaid them as he had done before, and inflicted a heavy defeat at Homildon Hill, to the north-west of Alnwick. After this time there is a distinct lull in border warfare. In the Highlands the clans are busily engaged in cutting each other's throats, and in the south the kings are doing all they can to curb the power of Douglas, and murder and torture stalk triumphant through the land. The Wars of the Roses begin in England, and the whole island lapses into a pitiable state of pillage and anarchy.

6. The Tudor Quarrels.-The accession of Henry VII to the English throne and the marriage, far-reaching in its results, of his daughter Margaret to James IV, seem to promise better things; but two periods of strife remain, viz. the Tudor quarrels, which form the close of the Border struggles, and the fights into which 
Scotland was unfortunately drawn to support the house of Stuart. It will no doubt be noticed that on one occasion only did the Scots gain a considerable victory over the English in the field, and that on no occasion did an English victory, however heavy at the time, produce any permanent result. Another important point-though neither of these has any direct geographical bearing-is that Scotland was often made the tool of France ${ }^{1}$ in her inveterate strife with England. This can be traced from Neville's Cross to Culloden with scarcely a break. The Flodden campaign, which comes next in chronological order, is a case in point. James IV attacked England partly to please the Queen of France and partly in revenge for the capture of Barton's great ship which was caught pirating in the Downs. Lord Home, the Scots Lord High Chamberlain, made a characteristic descent into Northumberland, and collected, as usual, great booty; but he was ambushed among the tall broom on Millfield plain, near Wooler on the Till. James followed with a royal army, in spite of many misgivings at home, and the entreaties of his wife. He entered England by Twizel Castle, at the confluence of Till and Tweed. After taking the Border fortresses of Norham, Wark, Etal and Ford, all within a radius of eight miles or so, he wasted a good deal of time till the Earl of Surrey (scion of a family well known in Scottish history) approached, and reached ${ }^{1}$ See Lang's History of Scotland, vol. i., p. 280. 
Wooler. Being unable to tempt James from a strong position, Surrey moved round to the northern and less steep side of Flodden Hill, until, crossing the Till near Twizel Castle, he bestrode James' path back to Scotland. James neglected to disturb this risky flank march, and allowed the enemy to cross the Till unmolested. ${ }^{1}$ The defeat was a crushing one, and there was hardly a noble family in the northern kingdom that had not a great loss to mourn. The inhabitants of Selkirk, Hawick and such places near, which had supplied the bulk of the defeated army, were decimated by the carnage, and everything seemed open to the invader. Edinburgh prepared to defend herself; but no great incursion was either made or contemplated. Jedburgh was taken, and Ferniehurst close by ; but no more was done. Twenty-five years later James V, refusing to take measures against the Roman Catholics at the dictation of Henry VIII, and goaded by France, projected an invasion of Northumberland; but many of his nobles refused to go, and he sent an expedition across to the western border, which was easily routed by an inferior force at Solway Moss. Negotiations were afterwards opened for a marriage between Prince Edward and Mary Stuart, but they were spoiled by the precipitate conduct of Henry and the strength of the Roman Catholic party under Cardinal Beaton. A fleet and army were sent in consequence and ravaged

1 See Lang's History of Scotland, vol. i., p. 378. 
Edinburgh and the country round, while untold damage was done nearer to the Tweed by Sir Ralph Evers. These measures did not tend to strengthen the liking of the Scots for the marriage, and the feeling grew so much that a body of men was raised strong enough to defeat the invaders on the Teviot near Jedburgh at Ancrum Moor. The useless and insensate struggle was continued by the Lord Protector Somerset when Henry VIII died, and yet another invasion took place. The Scots army posted itself behind the Esk at Musselburgh, but the Regent Arran foolishly threw away his advantage of position and crossed to meet the English. When he was defeated the river at his back made things all the more disastrous. Pinkie Cleugh was the last great engagement of a long and lamentable series, and also one of the greatest. Mary was, however, married hastily to the Dauphin, and French assistance and the fall of Somerset put an end to hostilities.

7. Mary Stuart.-The romantic career of Mary Queen of Scots calls for little comment here. Her two brief struggles teach no iinportant topographical lesson. Carberry Hill was fought by the nobles on their way to take Mary and Bothwell, who had fled to Dunbar, and was a very small and fortuitous affair. The Queen was imprisoned in Lochleven Castle, but escaped. She made her way into West Lothian and then across to Hamilton on the Clyde. Dumbarton was to be her stronghold, and the Regent was at Glasgow. He 
hurried to cross the Queen's path at Langside, and she saw the rout of her army from Cathcart Castle, due south of Glasgow. Fleeing into Galloway, she decided to escape into England, and nineteen years later she ended her days at the block in Fotheringay Castle.

8. The Marquis of Montrose.-The union of the crowns of England and Scotland in 1603 did a great deal in the way of promoting peace, but as soon as faction arose the Scots very naturally sided with their representative royal family, the Stuarts. Unfortunately, chivalry and race feeling carried them too far, and over a century passed before the land was free from the sore distractions of war. At first, it is true, Charles I found the Scots against him, owing to his reckless religious interference, and armies faced each other on the old ground, this time at Duns, to the west of Berwick. Happily, but little blood was shed. In the next year, 1640, an engagement actually took place. Lord Conway was attacked at Newburn, on the Tyne, a few miles to the west of Newcastle, and ignominiously defeated. Hence the Treaty of Ripon, the terms of which do not concern us here.

In due course, the northern Presbyterians sent an army to help Cromwell. His doings have been noticed in Chapter V. The absence of the Covenanters gave a golden opportunity to the loyalist Montrose, whose wonderful career has now to be reviewed. After raising 
a force of men sufficient for his immediate needs, he learned that Argyll, with a band of "Lowlanders," was intent upon protecting Perth. This meant the sealing up of the south-western end of Strathmore to the royalist Highland army. The battle of Tippermuir, just outside Perth, led to the surrender of the town to Montrose. Having only a small army and no fixed plan of campaign (being far removed from friends in England), the marquis marched suddenly through to Aberdeen, to rouse the Gordons, and there gained a success which was marred by much cruelty. Argyll was following him up slowly, and Montrose marched up the Spey, hoping still to rouse the Gordons. In this he failed, and he was headed off. He hid his cannon and baggage and entered Badenoch, passing into Athole and Angus-shire. $\mathrm{He}$ recrossed the Grampians, entering Strathbogie, and so passed once more into Aberdeenshire. The next that was heard of him was that, in December (1644), by wading through snowdrifts, scaling precipices, and traversing all but unknown mountain paths, he had dared to invade Argyll's own country, and was working havoc in the west. Argyll fled from Inveraray, to return later to. Inverlochy, near the present Fort William. Here he was attacked and defeated. Montrose then passed over to the north-east, and ai last raised the Gordons. Being compelled once more to retreat, he first made a raid upon Dundee, which he sacked. While the Highlanders were engaged in 
plundering the unfortunate town-for this, rather than a high-souled patriotism, was the motive force of most of them-they were compelled to retire by the approach of Baillie and Urry, and showed great address in their quick retreat. Two fierce engagements took place, one at Auldearn, between Elgin and Inverness, and close to Nairn, and the other at Alford, on the Don, twentyeight miles north of Aberdeen. Both were won by Montrose.

Plague had driven the Convention of Estates from Edinburgh, and they assembled at Perth. Montrose descended from the mountains and occupied Kinross, ravaging and burning in order to keep his half-savage army together. Both he and the Covenanters crossed the Forth, and came to blows to the south of the river and to the south-west of Stirling, at Kilsyth, on the southern edge of the Campsie Fells. Edinburgh and Glasgow were ravaged forthwith; but most of the strong fortresses still remained in the hands of the Presbyterians. The reduction of these, though vitally necessary, was too dry-as-dust a task for the victorious army, which was little more than a glorified marauding band, and nothing but a dazzling and successful invasion of England would satisfy Montrose. As Kilsyth was fought on August 15, 1645, and Naseby on June 14 of the same year, it does not appear that the royalist leader was destined to aught but ultimate failure, in spite of his previous brilliant successes. David Leslie 
crossed the Tweed at Berwick, and learned that Montrose lay quartered near Selkirk. Suddenly leaving the Edinburgh road near Musselburgh, he marched down the Gala to Melrose. Montrose lay where "the River Ettrick, immediately after its junction with the Yarrow, and previous to its falling into the Tweed, winds almost beneath the lofty banks on which the town of Selkirk stands : having upon the northern side a large and level plain, extending in an easterly direction ... to the high ground which forms the banks of the Tweed, near Sunderland-hall. This plain is called Philiphaugh." 1 Montrose was surprised and crushed, and King Charles' cause in Scotland was irretrievably lost. The intrepid marquis landed again, first in the Orkneys and then on the mainland in 1650, but he was captured and executed.

9. Oliver Cromwell.-The proceedings of Cromwell were brief and to the point. On the outbreak of the Second Civil War in 1648, after subduing a rising in Wales, he marched northwards to meet Hamilton's men, who were marching by the north-west route to join the Royalists in North Wales. Skilfully working his way past them, Oliver faced them at Preston with his back to Scotland, as Surrey had done at Flodden. The Scots were overpowered and cut in two. Further fights at Wigan and Warrington, farther and farther from home, sealed the fate of the remnants of the invading army. 1 Scott, Border Minstrelsy, vol. ii., p. 170. 
When Charles I met his doom, Scotland again rose against the regicides, and the Dunbar campaign took place. Marching through the Merse and East Lothian, Cromwell found the country abandoned by the population, and no Scots army. He approached the capital, being supplied with food, no doubt, by his fleet. The enemy he found posted from Arthur's Seat to Leith, and after a little preliminary skirmishing he retired to Musselburgh. His next effort was from the westward. The English army made a circuit towards the east end of the Pentland Hills, but Leslie immediately left his former position and took one which covered the city from the westward. Again Cromwell made for Musselburgh, and finally he began to retreat. He had to keep by the coast, and so Leslie was able to move by a shorter line (see Plate V) and bar his passage at the east end of the Lammermuirs. For some reason never quite satisfactorily explained Leslie came down to level ground ("went down against the Philistines at Gilgal"), and was in consequence disastrously defeated. Edinburgh Castle surrendered, as well as Tantallon (by North Berwick) and other strongholds. The south of Scotland was soon completely overawed. North of the Forth Charles, recently crowned, took up a position in front of Stirling, and behind the River Carron. Near Inverkeithing (north end of the present Forth Bridge) an army which had been sent by Cromwell to turn the position was victorious over Holborn and Brown. This 
rendered the position of the main Scots army very precarious, as supplies and information by way of the east coast and Strathmore could now be gradually cut off. Charles accordingly made a sudden dash westwards and southwards, and moving more rapidly than Cromwell had calculated, was not caught up till he reached Worcester. There his army was destroyed and the prince made a fugitive.

10. The last Stuart struggles.-We pass over the last two Stuart kings, as the interest of their reigns is not a geographical interest, but mainly a question of theology, and we come to the accession of William of Orange. Viscount Dundee took up the cause of James "the Third," and was opposed by MacKay, who marched towards Inverness against him. Dundee made southwards to Perth, where he seized a good deal of money, and then retreated into the Highlands again. A good deal of marching, counter-marching and skirmishing occurred, till Dundee made a move to Blair Atholl, the key to the northern Highlands, posting himself at the upper end of the defile of Killiecrankie. In the fight which followed MacKay was badly worsted, but Dundee was killed. Cannon, his successor, did not know the character of the Highlanders whom he led, and failed to improve upon the victory. The Fabian tactics of MacKay, and a Jacobite failure at Dunkeld, wore out the patience of the northerners, and they melted away. The next year General Buchan tried to revive 
the contest, raised about eighteen hundred men and quartered them in Strathspey. Sir Thomas Livingstone came up frum Forres, down the hill by Castle Grant (east of Grantown), and surprised the enemy at Cromdale. The Highlanders vanished. Fort William was then built, near Inverlochy, and the last embers of the struggle soon died out. By the end of William's reign, in spite of the massacre of Glen Coe and the failure of the Darien scheme, things were ripe for the Act of Union, which was actually passed in 1707. This, by giving the northern realm freedom in religion and trade, has been of the greatest advantage to Scotland. The growth of Glasgow is in part a commentary on this wise Act. Unfortunately, Scotland was twice more distracted by war, the intrigues of our then inveterate enemy, France, and the sentimental chivalry of the Highlanders being too much for the preservation of peace and contentment. Thanks to our use of seapower, both the risings, in 1715 and 1745-6, came to naught through lack of outside support.

In 1715, as before, the possession of Perth was allimportant to both parties. The Earl of Mar used it as his headquarters, and projected an attack upon Stirling. This he abandoned, and a Jacobite detachment was cut up at Dunfermline. On the 10 th of November, after many delays, Mar advanced to Auchterarder, and thence down Allan Water towards Dunblane. A confused affray took place at Sheriffmuir, and Mar retreated to 
Perth. This really ended a very ill-organized and half-hearted rebellion.

In 1745 matters were much more serious. Charles himself was on the scene for some time-though he does not appear to have been a very heroic or inspiring personage-and an early success gave the Jacobites heart for the fray. Sir John Cope marched northwards to Stirling with a small army of poor quality. Hence he decided to operate upon Fort Augustus. The rebels proposed to meet him at Corriyarrick Pass, but he prudently aroided fighting in a defile and made for Inverness. The enemy decided to invade the south, and reached Perth. Edinburgh was soon occupied by Charles. General Cope finally landed at Dunbar. Departing thence, he advanced towards Edinburgh, keeping quite close to the coast, and forgetting that light-armed Highlanders need not use the main road from the capital. $\mathrm{He}$ was taken in flank in consequence, but changed front and secured a good defensive position. In the night, however, the enemy worked round him again, and he hurriedly faced eastwards to defend himself. When the Highlanders charged, an unaccountable panic took place, and Cope's army was routed. He himself made across by Lauder to Berwick, the castle of Edinburgh, but not the city, being in English hands still. A month after, Charles marched out to Dalkeith and then to Kelso and Jedburgh. After this eastward feint he made for 
Carlisle, 1000 men short of his original 5000, owing to desertions. Though matters were going badly for the Stuart cause in the north, the prince insisted upon advancing upon London, as if England were defenceless. He moved to Penrith, and, neglecting Marshal Wade, an old and inactive man, who was making a demonstration against him up the Tyne, passed Lancaster and reached Preston. From Wigan he turned eastwards into Manchester, where he had a good reception, but failed to augment his army to any extent. Skirting the edge of the Pennines, he made by Macclesfield and Leek for Derby. Here he halted and then turned back. Cumberland lay at Lichfield, and soon started in pursuit. Stockport, Manchester, and Penrith were passed without any serious happenings, though a skirmish took place at Clifton, a village just south of the last-named. Carlisle was reached in safety, as also was Longtown on Esk, and the Highland troops made their way by Annan to the west. Their forces joined hands at Stirling, and Hawley, in the absence of the Duke of Cumberland, met them at Falkirk. The advantage lay with the rebels, and Hawley retired on Linlithgow and the capital. Cumberland again came north and assumed command. The Highlanders left Stirling and retreated by Dunblane and Crieff. One division then went northward by the Highland road, and the other took the coast route by Montrose and Aberdeen to Inverness. The pursuing troops occupied 
each district as it was evacuated, Aberdeen being made their headquarters, and beat off small attacks round Blair Atholl. The end came when the Duke was at Nairn. Charles attempted to surprise him, but failed, and retreated in some confusion to Culloden, where the armies faced one another on the open moor, much to the disadvantage of the Jacobite troops. The result is well known, and the Stuart cause never looked up again after the disastrous defeat and the rigorous measures of coercion which followed. These regulations were afterwards relaxed or repealed, and since the end of the eighteenth century there has been a real unity between the two kingdoms. Southern Scotland is not greatly different in manners and speech from northern England: but the people of the Rift Valley and the Clyde, i.e. the industrial part of the country, are more distinctive, and those of the Highlands in some ways widely vary, owing to the orographical features of the land, from those who live in the south.

11. Summary.-The historical geography of North Britain centres round the following:-

i. The northern and western islands, with the Caithness lowland, occupied by Scandinavian rovers at the first, and lost to them finally in $\mathbf{1 4 7 0}$.

ii. The mountainous and, with the exception of iii, well-nigh inaccessible Highlands between Glenmore and Strathmore, where great events have never moved, 

but where such men as Bruce and Montrose maintained an unequal struggle with wonderful success.

iii. The east coast lowland, dotted with such names as Northallerton, Durham (Neville's Cross), Flodden, Berwick (Halidon Hill), Dunbar, Pinkie, Edinburgh, Falkirk, Stirling and Perth. Most of the mutual history of England and Scotland has its interest here. If the topography of places mentioned in the previous paragraphs has been carefully followed, the importance of this great road will have received sufficient emphasis. iv. The transverse road from Newcastle to Carlisle, used by the raiding Douglases and containing Hexham, of Yorkist fame.

v. The western road from the Midland Gate of England along the Lancashire plain viâ Preston and Lancaster to Carlisle: used by Edward I, Cromwell and Prince Charles (Charles II). From Carlisle difficult country is found whether Nithsdale, Annandale or Eskdale is tranversed, until iii is joined near Falkirk.

vi. The Aire Gap, connecting iii and $\mathrm{v}-\mathrm{a}$ southern edition of iv, but wholly in England, and therefore of little international importance.

The whole of the history outlined in this chapter falls into the first four of these compartments, and the student will find no difficulty in identifying each as he revises the preceding paragraphis. 


\section{CHAPTER VIII}

\section{IRELAND AND ENGLAND}

1. General characteristics.-The history of Ireland is a long tragedy. Ever since the invasion of Strongbow the natural disunion of the island has been accentuated and aggravated by the nearness of a strong and wellorganized kingdom possessing an easy highway from the Midland Plain, after a short sea voyage, to the low coastline from Dundalk to Dublin. There is no physical barrier inland until the very extremities of Ireland are reached, save the bogs which are now largely drained. This marsh land, while it was invaluable for hiding or protecting small bodies of men, could never harbour a large force, and so it has always been possible to traverse most of the country without danger and to scatter the defenders into small parties which had small chance of uniting. The very ease with which Ireland can be penetrated has made it difficult to thoroughly conquer. It is too physically invertebrate. A glance at Plate VI will show how many easy pathways there must be, and it has been pointed out ${ }^{1}$ that it is possible to ride from

1 Mackinder, op. cit. p. 298. 
the central plain to the sea without exceeding an elevation of 300 feet by no fewer than twelve intervals through the hills, without including the broad entrance mentioned above. The drainage system of the centre (which can profitably be studied in Bartholomew's $\frac{1}{4}$-inch scale reduced survey sheets) is bewildering in the extreme, and only in the south is there a welldefined series of river systems. Hence the historical geography of Ireland will be found to be somewhat promiscuous. It consists of a study of the growth and shrinkage and growth again of the English Pale round Dublin, and of the use which has been made over and over again by foreign powers of Ireland as a steppingstone to England. Most of Ireland's troubles can be traced to the latter cause, but much is also attributable to the disunity of the inhabitants, and the sharp difference in religion which has brought much woe to the little land that has stood so firmly by the Roman Church.

2. Early Inhabitants.-The first occupiers of the land are not sufficiently well-established in history to be treated in any detail here. Formorians of Turanian origin, utterly savage, and destitute of knowledge of metals, pottery, perhaps even of fire, " rearing ugly little altars to dim, formless gods; trembling at every sudden gust, and seeing demon faces in every bush and brake," ${ }^{1}$ were the first of whom we hear aught. Next

1 The Hon. Emily Lawless, Ireland, p. 6. 
are supposed to have come Belgic Firbolgs, and the Scandinavian Tuatha-da-Danaans, between whom was fought upon the plain of Cong (between Loughs Mask and Corrib) a great and bloody battle; and then came the conquering "Scoti," whose history is quite as vague as that of their predecessors. Fact begins to emerge with the lives of Patrick and Columba and the conversion of the heathen inhabitants. But history is still " a confused chronicle of small feuds, jealousies, raids, skirmishes, retaliations, hardly amounting to war, but certainly as distinctly the antipodes of peace." Tribes had begun to aggregate, however. Connaught was in the hands of the O'Connors, Munster belonged to the O'Briens, Leinster to the McMurroughs, and Ulster to the O'Neils, who were supposed to be overlords or Ard-Reaghs of the whole island.

3. The Migrations.-Then came Picts and Norsemen and descended upon Ireland, a land of advanced culture. Lambay Island, near Howth Head, seems to have had the pleasure of first welcoming the Danes. Then the Boyne and Liffey were entered, as might be expected. One Turgesius landed in Ulster (probably in Belfast Lough), burnt Armagh cathedral, killed the monks, occupied the east coast, and then pushed across to Athlone, where the Shannon leaves Lough Ree. Defence seems to have been impossible, except in the well-known round towers, where the feeble could stay till the storm was past and fear nothing but a smoking 
out. The Northmen built and fortified towns, such as Dublin (never really Irish), Limerick, Waterford, Wexford and Cork. No assimilation took place in Ireland as it did in England, and the struggle was one of life and death. At last arose the great Brian Boru, or Boroimhe. The Danes of Limerick were fought by him in 968 near that town, and summarily massacred, and soon Brian became Ard-Reagh, won many victories over the Northmen, and even took Dublin. But after a lull the Danes stirred again. Their kinsmen in Northumbria, Man and the Orkneys came to help them, and the great battle of Clontarf took place on the strand leading to Howth. The invaders were routed, but Brian was unfortunately killed. Feuds and quarrels followed instead of peace, until the coming of Strongbow.

4. The Anglo-Norman Descent.-The expedition sanctioned by Henry II was sent from Pembroke, and the first party landed in Bannow Creek, a little to the east of Waterford Harbour. They made for Wexford, which they took, and Fitz-Stephen built a castle on the rock of Carneg near by. Strongbow himself came over early in 1170, the next year. A party landed in Kilkenny and defeated the Danes of Waterford, which town Strongbow himself took. Travelling through the Wicklow Hills, and picking up the first party at Ferns in Wexford, the army stormed Dublin. Meath was next attacked, and O'Rorke was defeated in defending it. 
But the tide turned, Strongbow was invested by sea and land in Dublin, and Fitz-Stephen was shut up in Wexford. Breaking through, the former hastened to Gloucester to meet his king and crave his assistance. Henry landed at Waterford in October, 1171. Everybody submitted to his large army without a struggle. Wexford, Tipperary, and Dublin were entered : all but Roderick O'Connor behind the Shannon and the northern chieftains swore allegiance, and Henry did a very great deal in the six months he spent in the country. Anarchy began soon after he left, and the new lords only really owned the land immediately round their castles. John, who behaved very foolishly as prince, came over as king to crush the De Lacys. He marched from Waterford to Trim, took the castle; passed due north to Kells, and thence to Dundalk, Carlingford, Downpatrick and Carrickfergus, and then back to Dublin.

5. Edward Bruce.-The battle of Bannockburn set Ireland in a blaze as well as Scotland. The O'Neills of Tyrone, near to Scotland, made overtures to the Bruces, and Edward landed at Carrickfergus in 1315 with a large army. Richard de Burgh, Earl of Ulster, was defeated and driven back to Dublin, and the Viceroy too was beaten. At Kells Bruce won another victory, and then passed down to Cashel with his brother, being crowned King of Ireland at Dundalk. But the Scots went too far in their destructiveness; 
the colonists recovered and won a great victory at Dundalk, where Edward Bruce was killed. His head was loyally sent to London, for exhibition.

6. Richard II in Ireland.-By 1394 things were in a very bad state in the western isle. Art McMurrough was master of Leinster : Limerick, Cork and Waterford were in a chronic state of semi-siege, and raids reached the very walls of Dublin. Richard came with a huge army and landed at Waterford, a pretty natural point at which to aim, as it was easily reached through the fairly broad coastal plain of South Wales. (Compare the Great Western Railway's new Fishguard-Rosslare route.) The great chiefs came in readily, but when he left they rose again and completely defeated the English troops at Kells, twenty miles due west of Drogheda. Richard came over again to Waterford in 1399. McMurrough prudently declined battle, and a disastrous march to Dublin was followed by the news of Henry's landing at Ravenspur. Richard hurried across to his doom, and more anarchy followed.

"The most salient feature in Irish history is perhaps its monotony. If that statement is a bull it is one that must be forgiven for the truth it conveys. Year after year, decade after decade, century after century, we seem to go swimming slowly and wearily on through a vague sea of confusion and disorder; of brutal deeds and yet more brutal retaliations; of misgovernment and anarchy; of a confusion so penetrating and all- 
persuasive that the mind fairly refuses to grapple with it." 1

7. Ireland under the Tudors.-In the time of Henry VII we come across the first definite attempt upon England from Ireland, that of Lambert Simnel. It was a feeble effort; but it is instructive. The impostor landed in Lancashire, passed the Midland Gate, and was beaten and captured at Stoke. Then Perkin Warbeck was started upon a similar errand, and landed in Cork, where he seems to have enjoyed himself and then went back to the Continent. We have done with him here, except to say that he made a foray upon Munster, where the townspeople gave him a poor reception, after which he departed.

In 1520 the Earl of Surrey, son of the victor of Flodden, was sent to settle Ireland, but did little, as he was not adequately equipped for such a task. But the time was approaching. The great struggle with Rome began, and fanned the embers of strife into a flaming and cruel war. The situation has been well summed up in the phrase-Religion led to rebellion, rebellion to conquest, conquest to plantation. That is the subsequent story of Ireland in a nutshell. Kildare was imprisoned and died in the Tower. His son seized Dublin city, and the archbishop was murdered, and towns near were burned, till Sir William Skeffington set out to attack Maynooth Castle. It was taken, and

1 Lawless, op. cit., p. 125. 
many of the defenders were hanged. This ended that rebellion. But the public destruction of holy relics at Dublin did what nothing else had ever done-it united all Ireland against the Crown, and things finally came to a head in Elizabeth's reign. Shane O'Neill was the first to rise, in Ulster, where he did much damage till Sir Henry Sidney was sent over. The latter traversed Ulster and entered Tyrconnel, reinstating the O'Donnells there, went on to Sligo and so into Connaught. Encouraged by an English disaster, Shane raided the O'Donnells, but was completely ruined in a fight on Lough Swilly, near Letterkenny. Desmond's rebellion was the next. He landed at Dingle, and after much vacillation, rose in arms. Pelham and Ormond made a concerted attack upon him, destroying every living being on their way right across Kerry. They united at Tralee and returned to Cork, leaving a desert behind them. But four Spanish vessels landed their men at Smerwick, a tiny place just north of the Blaskets, and a disaster occurred to the English in one of the Wicklow glens. Leaving the Pale for the moment, Lord Grey made for Smerwick, with such men as Raleigh and Spenser in his train. The place was taken and the garrison slaughtered. ${ }^{1}$ The rest of the rebellion was stamped out ruthlessly and in detail. The last rising in Tudor times was that of Hugh O'Neill. Ulster had

${ }^{1}$ Kingsley gives a fine description of this in Westward Ho! chap. ix. 
been untouched by the Desmond rebellion. It was Ulster's turn now. Private wrongs goaded Hugh into resistance, and a very lamentable affair it proved. The scene of operations was the northern Blackwater, boundary of county Tyrone, "Yellow Ford." A very serious defeat of the royalist troops was followed by flight into Armagh and thence into Dundalk. All Ireland blazed out into resistance. The Earl of Essex was sent over. $\mathrm{He}$ behaved in a most unaccountable way. Landing in Dublin, he went south instead of north, and then wasted precious weeks in the Limerick forests, two disasters befalling his lieutenants in Wicklow and Connaught. He went north, met Tyrone in friendly conference on the Lagan and agreed to an armistice. This could not be tolerated, and Mountjoy, a man who could, unlike Essex, blind himself to the awfulness of the tragedy, was appointed to take the reins. $\mathrm{He}$ established military bases all over the north, and proceeded to slaughter and starve. It was the only policy, and it succeeded. Tyrone's power faded. Fifty Spanish ships entered Kinsale harbour, and the town was occupied. Mountjoy lost not a moment, and surrounded the invaders. More Spaniards landed not far off, and O'Neill joined them, and tried to surprise the English camp. The attempt was a miserable failure, and Kinsale gave in. Tyrone saw that the game was over, submitted and was pardoned.

8. The Stuarts, Cromwell and William III.-The fall 
of Strafford, a capable if harsh ruler, was followed in 1641 by the awful Catholic rising. Happily we can pass over it till 1648, when Prince Rupert arrived with a small fleet at Kinsale to make capital, if possible, out of the disturbance. Jones, the Parliamentary general at Dublin, was pitted against Ormond and the rest of Ireland. Cromwell was coming. So Dublin must fall before his arrival. Marching from Kilkenuy, Ormond established himself near Rathmines, and was very badly beaten at a little place near called Baggotrath -a fight far more important than history admits. Cromwell landed at Dublin. Drogheda was crushed out, and Wexford's fate was as bad. The effect of these two fearful examples was immediate, and Waterford and Limerick alone held out for any length of time, the latter being the final conquest, owing mainly to its remoteness.

The next scene is the landing of the dispossessed James II at Kinsale. A glance at Plate II will show the reason for the venue of these continental expeditions. Avoiding the Channel, the south and south-west of Ireland afforded the only feasible landing-places. Londonderry was besieged by the Roman Catholics. James was in Dublin, and no one knew if he meant to be merely king of Ireland or to use Ireland as a stepping-stone. The Enniskillen troops under Colonel Wolseley had won a victory at Newtown Butler, on the road to Monaghan, but, on the other hand, Schomberg, 
William's great marshal, had failed to take Dublin. The king himself came over, landing at Carrickfergus, and met James on the Boyne. The result was the ruin of the Stuart cause. Behind the broken walls of Limerick the remains of James' troops held out nobly, but to no purpose. Ginkel, William's general, kept tight hold upon the outworks and then collected men in Mullingar for an assault on Athlone. Crossing the Shannon there, he passed by Ballinasloe to Aughrim, where the final victory was won on the slopes of a low hill, and Limerick fell.

9. Conclusion.-The rest of Irish history, including the rebellion of 1798 , is mainly political. The whole scene possesses but little scientific interest. Ireland has never had a chance of developing her natural resources. Population has diminished fearfully at times, political questions seem insoluble and the same may be said of religious problems. Capital is scarce. Only seven countries of the world possess less wealth per inhabitant than Ireland. Four-fifths of the people are engaged in agricultural pursuits, mainly unprofitable; the great resources of the country in the way of building and ornamental stones are but little exploited; the seventeenth century politicians of England scotched, and the eighteenth killed, a promising wool trade; and the total valuation (rural $£ 12,422,000$, cities $£ 2,770,000$ ) at $£ 15,192,000$ is out of all proportion to Scotland (with its immense unfertile and uninhabited tracts), 
Plate VI.

\section{IRELAND}

Statute Miles

$2010.9 \quad 20 \quad 40$

REFERENCE Height From 0 - to $250 \mathrm{Ft}$

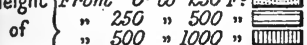
Land Above ............"...."

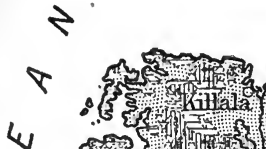

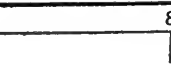

$8^{\circ}$

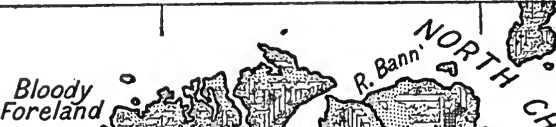
Q3

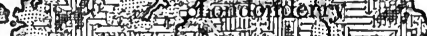
e \&. स.

R. Ernes Erne Achill

○

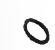

$0^{\circ}$

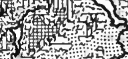<smiles>[As]=[As]</smiles>

Arran 150

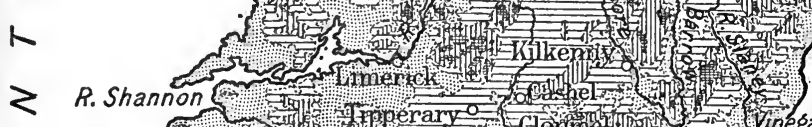
The alaskets;

Dingle Bay of

.0

gif

$\widetilde{T}$

Bantry Bay So

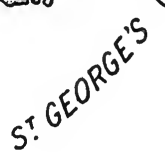

$\frac{1}{10^{\circ}} \quad \frac{1}{8^{\circ}}$



$£ 28,491,000$ and England and Wales £224,503,000. Ireland has been a weak neighbour or a too chivalrous buffer state between fierce contestants, and her career has been one of almost unbroken disaster, due in no indirect way to her geographical position and ill-defined orographical structure. 


\section{CHAPTER IX}

\section{POLITICAL DIVISIONS}

1. Organization of peoples.-After the struggles which give fresh lands to conquering tribes or nations, there comes the settlement. The land has to be apportioned, and the victors have to share the spoil. So it is when land is peaceably colonized, as occasionally it has been; the travellers settle down after dividing up the new territory. In the case of America this has largely been done mechanically: in the British Isles there are many points of interest in the way in which territory is organized. It seems pretty clear that the Saxons were dependent upon the tie of blood-relationship when they first occupied our lands, and that, in the course of time, this was superseded by the territorial idea. A serf born in a certain place was expected to stay there; there grew up a territorial militia or fyrd; and the union of the men of several districts, for purposes of war and civil justice, brought about the setting up of kings, who were, it is true, regarded as kings of the folk or people, but who sooner 
or later based their wealth and military strength upon the land.

2. The Settlements in England.-The nucleus or starting-point of the settlements in this country was the Kentish coast. The Romans began there, and the Anglo-Saxons, five hundred years later, occupied the same lands and, roughly speaking, adopted the same districts as their new settlements. The structure of the land, as previously explained, played its part in this, but the fact goes far to disprove the old notion that the invaders virtually wiped out their victims. A large stretch of imagination is needed to accept such a statement, and it is hardly to be supposed that the victors would pay any attention to the organization of the men they are said to have treated with such Timour-like thoroughness. East Anglia was the home of Boadicea's Iceni. The East and Middle Saxons controlled the lands of the Trinobantes and Catuvellanni. The Cantii and the Jutes both occupied Kent: Sussex was the home of the Regni and the South Saxons. We must not ascribe all this either to land structure as to the taking over of old settlements, nor must we assume that any district had well-defined boundaries.

3. The East.-London was well fortified by the Romans, and was accordingly-an important factavoided by the Teutonic invaders. Essex was accordingly formed, with the Colne and Chelmer as highways to the interior. London was cut off and no doubt fell 
automatically. Mr. Mackinder is of opinion that the name Surrey (south realm) implies the crossing of the Thames by these men. The occupation of East Anglia from the Orwell and Yare is easily understood, and Sussex was conquered, probably, from the Rother and the Arun. Kent, Surrey and Sussex were separated by the forest that evidently once covered the Weald, but which was gradually cleared away, mainly owing to the exigencies of iron-smelting.

4. Southern Counties.-The division of England into counties has been effected upon quite different bases. In the south, when the lowlands were thickly forested, settlements and colonies evidently originated on the open grounds emerging from these forests. If we imagine the Frome well wooded, Dorset in embryo is to be placed on the narrow strip between those woods and the southern coast. It obviously crystallized round the Roman Dorchester. Somerset may be placed across the Tone, Parret and Brue, reaching to the Avon. Wiltshire seems to have had for its nucleus a fort upon the high ground near Wilton and Salisbury. Berkshire, in its infancy, may be placed astride of the Marlborough Downs, spreading towards the Goring Gap of the Thames. Hampshire was the second part of the original Wessex divided by the Wilts settlement, and Kent, Surrey, Sussex and Essex have been already mentioned. Devon and Cornwall form, at once orographically, geologically and in a measure ethno- 
graphically, a separate entity, with the Tamar as a convenient administrative dividing line. This land, owing to its difficult nature (hills and morasses, interspersed with fertile valleys), became the home of refugee Britons, and its population is even to-day quite distinctive.

5. The Midlands.-The subdivision of the Midlands is merely a matter of the conquest of successive strongholds of the Danes. These warriors, as we have pointed out more than once before, knew the value of fortifications, both temporary and permanent, and they have left many marks upon history in the shape of place-names (e.g. Whitby, Selby). Alfred saved Wessex from the fate of Northumbria and Mercia by the victory of Ethandune (Edington? in Wiltshire), and agreed with Guthrum to use as a boundary a line "upon the Thames, and then on the Lea, and along the Lea to its source, then right to Bedford, then upon the Ouse into Watling Street." 1 This means that Alfred kept Wessex and added southwest Mercia; Bernicia remained in the hands of an English ealdorman stationed at Bamborough. Deira and Mercia, that is, in the land between Thames and Tees, remained in Danish hands. Guthrum held East Anglia, and the Five Boroughs of Derby, Lincoln, Stamford on the Welland, Nottingham and Leicester were governed by five jarls. North of them another chieftain ruled. London was Alfred's.

1 Hassall, Class-book of English History, p. 31. 
The conquest of the Danelaw was begun by Ethelflaeda, the Lady of the Mercians, sister of Edward the Elder of Wessex. Chester was fortified in order to prevent union with the Northmen of Ireland. From similar motives, fortresses were erected at Bridgnorth to defend the middle Severn, at Tamworth and Stafford to command Watling Street, and at Edisbury south of the Weaver to keep the Welsh back. Warwick was garrisoned, and Runcorn on the Mersey. Derby and Leicester also fell, to be soon followed by Stamford and Nottingham. Manchester was strengthened, and Bakewell in Derbyshire was seized to secure cross-communication. In the east, Huntingdon and Colchester fell, and gave East Anglia to Edward.

Thus Middle England had fallen into Anglo-Saxon hands. As it was conquered it was divided into shires (cf. shear, shorn). These naturally were selected as pieces of land around and depending upon fortified posts, and the geographical position of the following county towns should be carefully studied: Gloucester, by the Severn, midway between the Cotswolds and the Forest of Dean; Worcester, in a similar position higher up the river; Hereford, the focus of a dozen important roads astride of the Wye Valley; Shrewsbury, mentioned in Chapter X; Warwick, occupying on the Avon, a left-bank tributary, a position corresponding with that of Hereford on a right-bank affluent of the Severn; Oxford, where the Cherwell joins the Thames; 
Buckingham and Bedford on the Ouse; Hertford on the Lea, a highway to the Thames; Northampton on the Nen, looking, like Bedford, towards the Wash; and Derby, Stafford, Leicester and Nottingham, all guarding the line of the Trent, and watching the Midland Gate on the one hand and the Humber entry on the other from the mouths of secure valleys leading into the heart of the Pennines. The old Cheshire, reaching to the Ribble, and the broad acres of Lincolnshire, mark the end of this process of assimilation and conscious departmental or county reconstruction.

6. Northern England.-The size of Yorkshire is quite anomalous, and is due, says Mr. Mackinder," "to the late and incomplete subjugation of Northumbria by the West Saxon kings. In a region so remote from the base of operations the systematic, almost mechanical reorganization of the Mercian plain could not be attempted. Yorkshire is the Danish kingdom of York which succeeded to the Angle kingdom of Deira." It is interesting to note that even this county has its districts or divisions, which may or may not have been official, e.g. Hallamshire, round Sheffield; Craven, round Skipton; Holderness, the low east coastal strip; and Cleveland round the Jurassic hills of the North Riding. Beyond the Tees, Durham on the Wear became the nucleus of a county division, and the earldom of Northumberland, formerly a kingdom stretching from 1 Op. cit, p. 207. 
Humber to Forth, remained as the shadow of past greatness. Cumberland and Westmorland were later additions. They belonged to Scotland until the time of Rufus, and with the large and straggling county of Lancashire, date, as counties, from Norman or early Angevin times.

7. Wales.-Wales has a physical entity which is quite distinct from the neighbouring parts of England (see Plate IV). The structure of the country has already been discussed in some detail in Chapter VI. It now remains to see what scientific basis there is for its present county divisions.

Before the Edwardian conquest the land of Wales consisted of three main physical divisions, Gwynedd, Powys and Dynevor. Gwynedd is approached from Chester, Powys from Shrewsbury, and Dynevor from Gloucester. The government was done by chieftains of the Welsh royal race. Small principalities gave place to shires with fixed boundaries, and princes gave place to sheriffs. The most obvious unit was Môn, now to be called Anglesey. It was secure and fertile, and contained, in Aberffraw, the royal demesne of the princes. Snowdon, the culminating land of the north, was the nucleus of Carnarvon, which included the promontory running south-west to Ynys Enlli or Bardsey. Merioneth, as a division, presents no features of interest. It stretches from Snowdon to the Dovey. Eastwards lay the four cantrevs which had revolted against Edward 
previously to 1284, now Denbigh and Flint. South of the Dovey two castles had been built, Carmarthen and Cardigan. From these two counties were formed after the style of Leicester or Hertford. Glamorgan was formed from the old Morgannwg, and Gwent became Monmouthshire. Brecknock was placed astride of the upper Usk, Radnor between the Wye and the Teme, and Montgomery on the Vyrnwy and upper Severn. Pembroke, one of the former marches of Wales, remained as before. In conspicuous places, castles were built, and they were of great value to the conqueror. Conway was built on a rocky hillock surrounded by sands. At Carnarvon a fine edifice was erected on a tongue of land forming part of the delta of the Seiont. Beaumaris was placed in a commanding position on Menai Strait, and Criccieth on a rocky peninsula opposite to Harlech in Merioneth. Towns sprang up round these strongholds and charters were granted to them; and thus the old tribal system was gradually broken down.

8. Ireland.-In a general way, the political divisions of Ireland are readily correlated with its physical features; but, owing to the comparatively level nature of the interior and the wonderful complexity of its drainage, frontiers in a small way have always been easily obliterated and others substituted. Ulster, a tribal federation in Norman times (as also were the other three provinces so well known at the present day), 
consists in essence of the northern highlands of Donegal and Antrim. Leinster surrounds the Wicklow hills. Munster is the mountainous south-west, and Connaught has its origin in the highlands of Nephin Beg and Connemara. From these nuclei we can imagine frontiers extending till they meet in the middle of the island. This process is easily comparable with the growth of Surrey, Kent and Sussex, mentioned in paragraph 3 of this chapter. Plate VI should be carefully studied, and an attempt made to fix natural boundaries to the four provinces, the result being afterwards compared with a political map. The Shannon is an obvious dividing line between Connaught and Leinster, but county Clare somewhat irrelevantly belongs to Munster. None of the streams running into Waterford harbour, except the Barrow, between Kilkenny and Carlow and Wexford, form boundaries either for county or province; and in the north Ulster becomes Leinster without the slightest reference to any physical feature except Carlingford Lough. Earlier divisions ${ }^{1}$ have some features of interest. Cavan once belonged to Connaught and Louth to Ulster. Thomond, a part of Munster, lay astride of the lower Shannon, Desmond included the basins of the Bandon, Lee and Blackwater, and Ormond lay across the Suir. Further than this it is only necessary to notice that Ireland was settled, like Mercia, as a conquered country. This was begun by 1 See Poole's Oxford Historical Atlas. 


\section{POLITICAL DIVISIONS}

the Tudors, or rather under them, and completed by Oliver Cromwell. King's and Queen's Counties were named after Mary Tudor and her loving husband, Philip of Spain, Londonderry was occupied by the enterprise of the twelve Livery Companies, and Antrim and Down became a Scots plantation. Apart from all this, the county divisions of Ireland present virtually no scientific features.

9. Scotland.-Scotland is a country of great physical complexity. When one considers the cross-divisions and race, arising from the occupation of various points d'appui by Picts, Britons, Romans, Angles and Irish Celts, and the partitions, fortuitous or natural, arising from this fact; the debatable land fought for by Lothian or West Saxon warrior, and held by either, and the clan organization due to the number of glens and straths devoid of good cross-communication, one does not wonder at the intricacy of Scottish history. But certain broad considerations will give us a fairly effective view of the scientific side of the political constitution of Scotland. Earlier events, when North Britain was any man's land, are discussed elsewhere. It is sufficient here to point out the rise of two powers remote from one another, and the gradual absorption of the land between them. One had its focus on the rock fortress of Edinburgh : the other may be said to have rested upon London. The Scottish kings had for their fastness a castle which watched, and still 
watches, the Rift Valley westwards; Fife and Strathmore viâ Stirling; the Solway levels to the south; but above all, along the east coast, the low strip of land leading to the Vale of York and the English Plain. The rise of Wessex and the conquest of the Danelaw have been touched upon earlier in this chapter. The Anglo-Saxons, it will be remembered, drove their conquests from east to west until stopped by the sea near Chester and Bristol. Cornwall, Wales and Cumbria were thus cut off the one from the other. They themselves were overcome by the Northmen, but Bernicia (see p. 128) was still English. So it came about that there were two semi-independent realms, 'Strathclyde,' which politically included the Lake District, and Bernicia, ready to be carved up by the greater powers to north and south. Much discussion and not a little fighting led to the compromise made by Rufus. This gave to Scotland part of Bernicia, as far south as Berwick, and Strathclyde proper, as well as Nithsdale, Annandale, and Eskdale with remoter Galloway. In short, the Solway Firth formed a convenient break, and Solway Moss a suitable neutral ground. The Tweed, too, on the east, had strong claims as a boundary, but Berwick, the border fortress, had a sadly chequered history, so much so that when it was finally attached to the English crown treaties between the two countries referred to "England, Scotland and Berwick-on-Tweed." 
As far as county organization is concerned, Scotland belongs to the class of country which bases its divisions upon districts surrounding strongholds. We have seen this in the case of Mercia, and an instructive converse instance in the case of North Wales, where Edward selected his districts and then built his castles. Only a few Scottish counties are not named after towns, viz., Caithness, Sutherland, Ross, Orkney, Bute, Argyll and Fife, and with the exception of Fife the reason is not very far to seek. The far north has always been too barren to support a large population, and has in consequence never been either a stronghold or a land to be coveted; and the western islands and peninsulas are too disjointed to have any focus. They have just been loosely organized into counties as expediency has suggested.

There is not much to be learned from the distribution of the Scottish counties. Caithness, Sutherland, Ross and Cromarty, Inverness, Nairn and Elgin will all be found to have their drainage focussing on the Moray Firth. The lowland portion alone has political or historical importance in any degree whatever. Aberdeen and Banff form the lowland shoulder of Moray and Buchan; Stirling, Perth, Kincardine and Forfar are based on towns commanding the northeastward road through Strathmore-practically the only great highway. The Lothians, Linlithgow, Edinburgh and Haddington, occupy a similar position on 
the way to and from South Britain. Berwick is separated from the last-named by the Lammermuir Hills, and Roxburgh, Selkirk and Peebles are parts of the Tweed basin. On the west, Kirkcudbright and Wigtown are the ancient Galloway. Dumfries lies astride the very important dales of Nith and Annan, two routes of the highest historical and economic importance. Ayr occupies a fairly important west coast road leading to Glasgow but from nowhere in particular. The Clyde is taken up by Lanark in its upper course and Dumbarton and Renfrew on either side its estuary. Bute and Argyll comprise the islands and peninsulas of the west not already included. 


\section{CHAPTER X}

\section{SEA-POWER AND HISTORY}

1. Importance of Sea-Power.-No treatise dealing with the history of the British Isles, however brief, can close without giving space to one of the most important aspects of our national life, viz., the part played by our navy. At the present day we are more than ever dependent upon the preservation of our interests upon the ocean, and we rely less and less upon the resources of our own little islands. In former days, when the world's commerce began suddenly to expand, England was the country which stood in the forefront of progress. We had a very long start indeed, both of the Continent and of America, and we made magnificent use of that start; so much so that it is only within the last few years that other nations, with immeasurably superior resources and vastly larger productive areas, have begun to surpass us. It is easy to illustrate how this country has utilized its means. In $1901^{1}$ our estimated area of coal-fields was

1 Commercial Geography. Chisholm. 
11,900 square miles. The United States then possessed about 192,000 square miles. Our production was $225,000,000$ tons; that of the States was $245,000,000$ tons. The contrast in proportionate output is very striking. Again, if we turn to wheat production, we find that Russia, with its magnificent soils, produces eight bushels per acre, France nineteen, the United States thirteen, Argentina nine, Holland and Belgium twenty-eight, and England thirty. Our opportunities are used up to the last ounce. The population of our islands, however, has increased so enormously that the land has not been able to feed its inhabitants, and greater and greater quantities of foreign and colonial foodstuffs have been imported. A few figures will illustrate this. ${ }^{1}$

2. Imports and Exports of the United Kingdom.Grain and flour were imported in 1905 to the value of $£ 70,100,000$. Foreign meat cost us $£ 49,400,000-a$ truly stupendous sum. The bill for other food and drink, including such an item as some $£ 10,000,000$ worth of Danish dairy produce, came to $£ 109,200,000$. We exported $£ 18,500,000$ worth of food and drink. As a set-off to these colossal figures, we may quote those relating to the export of coal, $£ 26,100,000$; iron and steel, $£ 31,800,000$; machinery, $£ 23,300,000$; woollen goods, $\mathfrak{£} 30,000,000$; and cotton goods, the huge total of $£ 92,000,000$. To sum up, we took in goods to the

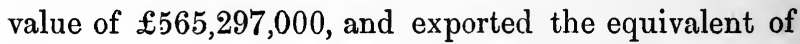
${ }^{1}$ Atlas of the World's Commerce. Newnes. 
$£ 330,023,000$. Such is the commerce over which the nation must watch. How urgent is the need of peace and security may be shown by giving a few of our sources of supply. The Continent sends us sugar to the amount of $28,000,000$ cwt. The United States send us $12 \frac{1}{2}$ million cwt. of raw cotton, 75 per cent. of our total supply. We buy from abroad, from America, India, Australia, Argentina, Russia, and other countries, wheat to the value of $£ 34,292,000$. This is 78.4 per cent. of our consumption. Rather more than one-fifth of our wheat is home-grown. All our tea, of course, $2 \frac{1}{2}$ million pounds of it, comes from without. Nearly one-third of our iron ore, about five-sevenths of our wool, all our silk, nearly all our gold and silver, all our indiarubber-to mention only a few items-come from outside. If our imports were stopped for a month or two we should be on our knees. No country has ever been so utterly dependent on the sea, and no nation has ever owed so much to the sea in the past.

3. Treatment of Naval History.-It will be impossible in a work of this compass to deal thoroughly with this most important phase of our natioual life. Nor will it be practicable to treat it regionally. Nevertheless, although the most we intend to attempt in this chapter is a chronological summary of our naval history, it may be well to point out the controlling circumstances affecting our principal naval struggles. Many of these have been defensive; more have been offensive. Any- 
thing more aggressive than the British Navy of the seventeenth and eighteenth centuries can hardly be imagined. Yet, paradoxical though it may seem, our plundering expeditions in the days of Drake and our long, fierce chases after Villeneuve a hundred years ago had a very important defensive element in thein. They were part of a struggle for very existence. At the present day we have a white population of some ten millions in our colonies. Many of these, no doubt, are wastrels, but the majority are men and women of the finest, and are serving a double purpose. They relieve undue pressure in the struggle for existence at home, and they are developing fresh countries abroad. Some of the most useful and most varied experience gained by our leading engineers has been won in the colonies. Some of the grandest opportunities for the best intellect of the universities are to be seized by those who enter the Indian Civil Service. Emigration, when it is undertaken for healthy reasons, is a very excellent step for the young and energetic. When we fought the Latin races in the uttermost parts of the earth, then, we fought not merely for supremacy, but for life itself. Napoleon threatened us. We destroyed his navy. That was not enough. Every other navy had to be destroyed or absorbed as well. For, had we not done so, they might have been used against us, to our perpetual hurt.

4. Offence and Defence.-Always bearing in mind the 
larger issues mentioned above, we will now point out that, on the whole, the battles of our navy which took place near our shores were fought to guard those shores. Those fought farther away were of an aggressive character. In the light of these statements, it is very instructive to note that the early struggles of our vessels were almost exclusively confined to the narrow seas. As the ages rolled on, however, the thunder of our guns was heard less and less in the Channel, and more and more outside the ports and in the territorial waters of our enemies. This fact is significant.

In spite, then, of the title of this book, and at the risk of a slight inconsistency, we will now proceed to epitomize the naval listory of England, as being inseparable from the geographical conditions which have modelled the history of our country. This epitome must necessarily be chronological.

5. Beginnings.-Ships and sailors have always played an important part in the history of England. The foundation of England as a nation was due to a maritime people. The Angles and other Teutonic races became Englishmen entirely owing to their exercise of naval supremacy. They lost their independence because they did not maintain the power which in the first place enabled them to prevail. When the Danes came to our shores, the islanders had no ships, except that fleet which is said to have routed the Northmen's vessels off Sandwich, their headquarters. 
With the advent of Alfred, however, a new era began. Difficult though it is to decide between the true, the shadowy and the false, we may assert that as early as 876 the Danes landed in Dorsetshire, and a detachment of the king's infant navy successfully engaged their seven vessels, capturing one. An engagement also appears to have taken place off the mouth of the Exe in 877. By 901, when Alfred died, a strong English fleet commanded the Channel. This was not only necessary in order to keep off the Northmen, but it was also essential that the pirates who infested the northern seas should be kept under, and one successful fight against them, at least, is recorded.

6. Naval annals begun.-Edward the Elder was not slow to take up the cue given him by his father. $\mathrm{He}$ gained a victory over the Danes off the Kentish coast. Athelstan, his successor, showed sympathy with the good cause by enacting that any merchant who made three voyages on his own account should be raised to the rank of thegn. Edgar, one of the greatest of early kings, raised, as the monkish writers tell us, no less than 4000 galleys. Stories like this, if inaccurate, serve to illustrate truths. It is also on record that the king made an annual circuit of his coasts. Even Ethelred II had the sense to attempt the defence of the country by enforcing the building of a vessel upon every owner of 300 hides of land. But 800 ships and 30,000 men do not seem to have made a very brave show against Swegen. Under 
Edward the Confessor we hear of the Cinque Ports Hastings, Sandwich, Dover, Romney and Hythe. The Conqueror added Winchelsea and Rye, and the position of these harbours is sufficient to show their purposethe guarding of the narrow seas. Certain privileges were granted them on condition that each port should furnish, as occasion arose, a number of ships and men for fifteen days, after which time the Crown took over the expense. The sea-power of the Norman and Angevin kings depended largely upon the Cinque Ports. King Harold's fleet in 1066 was in the Humber, whither it had been called by Tostig's inroad, and so the Conqueror's invasion was unchecked. Henry II was supreme from Calais to Finisterre. Thus early was England realizing her dependence on the sea.

7. The Crusades and the French wars.-The early Norman days were days of commercial development, especially in relation to our trade with Flanders. English wool was exchanged for the woven fabrics of that country and for the wines of Gascony and Aquitaine. When Richard I left for the Holy Land, he had a powerful fleet, which was of very great service. Cyprus was captured, valuable service was rendered in cutting off supplies from Acre, and a large Saracen fleet which included one gigantic vessel was heavily defeated. Even John, so reviled, and justly so, by historians, had an excellent notion of the importance of keeping up a good sea force. Philip Augustus had been commissioned by the Pope to 
detbrone him, and a large fleet was collected at the Flemish port of Damme. William Longsword surprised the vessels when most of the crews were on shore, and wiped out the whole armament. After John's death Louis came over to England to take the crown, but he was besieged in London, and Hubert de Burgh, the Justiciar, left Dover to meet the French fleet. A great victory was won off Sandwich, and peace was soon made, Louis retiring to France. This fight is well known by reason of the stratagem successfully employed by the English of sending clouds of unslaked lime down the wind into the Frenchmen's eyes. This fact is an interesting commentary on the geology of the district.

In the reign of Edward III we begin first to see the enormous value and superiority of our national seamanship. English and French alike were increasingly guilty of piratical raids, especially the former, and English carcasses, along with those of hogs, were not unfrequently to be seen hanging from Norman yardarms. Things reached a climax when Edward set out to invade France. A gory encounter took place at Sluys, at the mouth of the Scheldt, and the French were completely defeated. Edward's ships, too, were able to render great service at the capture of Calais. In 1350 the naval pretensions of the Spaniards were damaged in a fight off Winchelsea, but in 1373 Henry of Trastamare, the rival of Pedro the Cruel, inflicted a severe defeat upon us off Rochelle, and we lost command of the sea. 
In consequence, our possessions in France rapidly dwindled away. French and Spanish vessels roamed the Channel unchecked, and devastated many of the southern ports. The Earl of Arundel, in 1387, prevented a great invasion by capturing more than 100 of the enemy's vessels in the narrow seas and destroying many more at Sluys. The only other naval event of importance in the war was the defeat of a French attempt to recapture Harfleur from the sea side in $\mathbf{1 4 1 5 .}$

8. The Tudor Navy.-We come now to the age of discovery. Hitherto almost all the doings of our vessels had been confined to the seas around us. Now began an age when rivalries commenced much farther afield, and the craft of Italy, Portugal, Spain and England began to brave the dangers of the great oceans. It is really amazing to consider the marvels that were wrought by tiny ships of a hundred, and even of fifty tons. The mariner's compass had been invented, and the Italians had long used their admirable portolani, or charts, and mere coasting was no longer necessary. Hence the dawn of the sixteenth century marks an epoch in history. ${ }^{1}$ The Turks had captured Constantinople and shut up the landward route to India, and necessity drove the Christian nations to find their way round Africa and across the western seas.

Henry VII was profoundly interested in naval matters. He was a first-rate man of business, and was ${ }^{1}$ Beazley, Dawn of Modern Geography. 
largely engaged in mercantile speculations. For the first time, then, we hear the cry for new markets, one of the many important trade problems of the present day. Henry was the first English king to see the necessity for guarding our mercantile activities by a large and permanent force of warships. The Great Harry is well known as the first vessel of the regular British Navy. It was not long before our ships were in active service. A drawn battle took place with the French off Brest in 1512. Brighton was burned in 1514, Boulogne was taken in 1544, and an English fleet was of great use off Pinkie in 1547.

In Elizabeth's reign our ships began definitely to challenge the supremacy of Spain in the New World. The exploits of Drake and Hawkins are well known, and the defeat of the Armada has been fully dealt with above. Suffice it to say that one of the great questions of world-history was now to be decided, the question of the predominance of Teuton or Latin in America. The Armada deliverance prevented the blotting out of England. It did more : it enabled her to expand. From 1588 to 1815 , almost without a break, a terrific struggle went on all over the world, mainly between France and England. Its culmination is the Seven Years' War, when what is perhaps the most stupendous phenomenon in the world's annals became an accomplished fact-the British Empire.

9. The Stuarts and the Commonwealth.-James I's 
interest in the navy was profound. No doubt much of the attention that was paid to the fleet was due to the Commons, but the king himself showed a decided appreciation of things by establishing the Shipwrights' Company and granting charters to Virginia and New England. But he was no administrator, and his navy "reaped the whirlwind the sea-pirates of Elizabeth had sown." The phenomenally profitable privateering of her reign had attracted oceans of commercial scum to the occupation of Drake and Hawkins. Dishonesty and peculation reigned in every department of the administration, and the strong hand was not there to control. The Newfoundland Company lost some $£ 40,000$ from piracy, and even the Thames was invaded by rovers. Still, some fine navy vessels were built, including the Sovereign of the Seas, our first three-decker.

Charles I's naval efforts were few and inglorious. Quarrelling first with Spain, who had played at being friendly with us in order to keep James I from helping his dispossessed son-in-law in the Palatinate, Charles sent an expedition to Cadiz, badly manned and abominably provisioned. The affair was a gross and grotesque failure. Richelieu of France next, who had incurred many hard words in England by employing eight of our ships against the Huguenots, was attacked by the Duke of Buckingham. The island of Rhé, at the entrance to La Rochelle harbour, was the scene of operations, and witnessed the disgrace and humiliation of 
the prestige of England. It seems clear, however, that Charles did keep the navy in a fair state of efficiency, and that he preserved a semblance of power in the narrow seas. Ship-money, illegally levied as it was, was not entirely diverted from useful ends. How different, however, was the picture in Commonwealth times!

10. Cromwell and Blake.-When Cromwell assumed the direction of affairs there were only fourteen twodeckers in the navy, and the entire force consisted of less than a hundred sail. Never really strong since the Spanish Armada times, our fleet had fallen into absolute neglect during the long years of civil strife succeeding the meeting of the Long Parliament in 1640. Cromwell, however, changed all that. In five years he had created fifty ships of the line, and a force of twenty thousand seamen. At this time Dutch sails whitened every sea; their ships brought merchandise from every clime. Holland held the field, and she realized to the full that she must be in a strong position to defend her holding. The events which led to war with England need not occupy us here. But the scenes of strife are instructive.

The first important meeting was before Dover. The most casual glance at Plate IV will show that the Scheldt mouth is opposite the Thames estuary, and that rival fleets were certain to meet between Texel and the Devon coast. On this occasion, November 1652, the Dutch had decidedly the better of it. Blake 
drew off into the Thames after a desperate fight, and Tromp stood for the French coast to get his fleet together for another attack. This is the occasion immortalized by the famous legend of the broom at the mast-head. In the following February the same antagonists met off Portland Bill, when a three days' struggle brought substantial success to neither side, though our lost command of the sea seems to have been regained. In June and July, however, important victories were gained by the English, the position of the latter engagement, off Texel, showing how far our fleet had progressed since its defensive engagements near Dover. The Commonwealth had demonstrated its superiority to the whilom naval world-power.

The Barbary pirates having been put down, Spain was the next power to suffer. Free trade and toleration were pills far too large for the king to swallow, and war followed. Jamaica fell into English hands, and sixteen treasure-ships were captured at Santa Cruz in the Canaries, after a marvellous fight. The Spaniards ascribed their utter defeat to the fact that it was not men but devils that attacked them. Since Texel, then, England had been on the offensive.

11. The later Stuarts.-The strife with Holland was renewed under Charles II. The taking of New York, the Guinea Coast disputes, the ambition of the Duke of York and the resentment of Charles himself at the scant courtesy he had received from the Dutch 
during his exile, fanned the flame of war once more. June 1665 saw the Dutch attack the English off Lowestoft, a very natural meeting-place. The Dutch, though decisively beaten, did not despair, and fitted out a large fleet. Albemarle met it off the Goodwins, and a four days' fight took place in the Straits of Dover. Entire lack of discipline and the jealousy of Rupert led to a serious reverse. In a few weeks, however, a fierce action off the North Foreland gave the victory to the English, and the second Dutch war came to an end.

The Plague and the Fire followed, and our fleet decayed. But it was to the insensate frivolities of Charles II, and his total neglect of his most ordinary duties, that our succeeding disgrace came. The Dutch dockyards worked night and day. Charles took it all with the utmost unconcern. Indeed, ships were laid up and scores of crews disbanded. Only two small squadrons remained, one at the Nore and one at Spithead, while our foreign fleet consisted of a few vessels in the West Indies. The Dutch sailed up the Thames, up which no enemy's fleet had sailed since the time of the Danes. A detachment was sent against Sheerness, and its fort was destroyed. The Medway was entered, and eight vessels penetrated as far as Upnor. An advance up the Thames was stopped by the conclusion of peace. Again war broke out in 1672, Charles breaking faith with the English people and the Dutch as 
well, in order to secure French gold. At Southwold Bay, on the Suffolk coast, the allies met the Dutch. The French made off as soon as the work began, and such serious damage was inflicted upon our fleet that nothing could be done to menace the coasts of Holland. This was further ensured by the "indecisive" engagement off Texel a month or two later.

12. The Revolution.-James II restored the navy to some semblance of its former strength; but when he most needed it, it went over to the enemy, and William of Orange was able to land at Tor Bay without the slightest opposition. Had this not been the case, a heavy blow might have been struck at the armament that escorted England's future king. When the horse was gone, to use a familiar figure, the Jacobites tried to lock the stable door by getting a French fleet to help them. Louis XIV's ships fought a successful engagement with ours in Bantry Bay, and also administered a severe defeat off Beachy Head, the scene of many a former fight. Luckily for England, the advantage was not followed up, and a formidable fleet was fitted out against Louis, numbering ninety-nine sail. Off Cape La Hogue the French, with less than half that force, were badly beaten, and the hopes of James II were quite shattered. Once more was demonstrated the enormous importance of sea-power.

13. From Defence to Offence.-As the subsequent struggles of the navy recede farther and farther from 
the narrow seas, we shall be able to move more rapidly from this point. On land, under William III, England was hard put to it in the European conflict: on the sea, she began to carry out a policy of expansion. 1704, in Queen Anne's reign, saw an event of immense importance-the taking of Gibraltar, the key of the Mediterranean. Anson's voyage round the world in 1740 was a symptom of the new spirit of aggression. Yet small affairs near home showed how strong we were in the possession of our commanding sea-power. Charles Edward's crossing in 1745 was jealously looked for, but British vigilance did not avail, and victory had to be won on land. Passing on, we note Byng's failure at Minorca, at the beginning of the Seven Years' War. This frightful struggle, which made the modern German Empire, with Prussia at its head, an almost inevitable contingency, which won us India and Canada and decided the question of the predominance of Teuton or Latin in colonial enterprise, is signalized by no purely defensive naval engagements. Pitt sent expeditions against the French coast to nip in the bud the activity of the dockyards. St. Malo, Rochefort, Cherbourg were attacked with varying success, and the Toulon squadron was badly mauled by Boscawen. But Hawke's marvellous victory at Quiberon Bay, by which the Brest fleet was wiped out, dwarfed all other achievements. This was in 1759, our greatest of all years. It may be mentioned in passing that France let slip a grand 
opportunity of seizing India by not adequately supporting Labourdonnais, who alone seems to have realized how needful it was to keep the English from landing men, and who quarrelled with Dupleix and spent some years in the Bastille in consequence. The lamentable war of American Independence brought France (among others) into the field against us; but D'Estaing, who had it in his power to do us irreparable injury, left us alone, and Rodney achieved triumphs in the West Indies and off St. Vincent, sensibly prolonging our struggle with the States thereby. It was at this time, too, that Gibraltar successfully resisted its three years' siege.

14. The French Revolution.-The French Revolution hurled the world into turmoil. The European powers tried to unite in order to crush the embryo Republic, but mutual jealousies prevented effective operations. At sea, however, England was to the fore, as in the battle off Ushant on the "Glorious First of Junc," 1794. The years 1797 and 1798 were crowded with naval events. The names of Jervis and St. Vincent, Duncan and Camperdown, are a sufficient reminder of what was going on. With the arrival of Napoleon on the scene the world's strife waxed fierce and furious. The battle of the Nile (Aboukir Bay), the defence of Acre, the grim fight at Copenhagen, and the crowning victory of Trafalgar need no citing here. Napoleon declared, when he assembled his grand army at Boulogne in 1804-5 for the invasion of England, that he would subdue England 
if he could gain command of the Channel for seven hours. He would probably have required sixteen hours, but Nelson and his captains, by tedious and wearisome blockading of Brest, Toulon and other ports, prevented the Emperor from having the run of the Channel for even one hour. Thus it was that thirty miles of sea proved the ruin of the great project of invasion.

15. Conclusion.-With this last menace to our insular security we leave the subject of the navy. Enough justice has not been done in English history to this branch of the service. It seems to be taken as a mere matter of course that we were able (for instance) to send troops to India, to Canada, to Prussia, to Gibraltar, without serious molestation. The overwhelming predominance of the British navy has, indeed, been almost a commonplace of modern history. It must not be forgotten that our sea-power must not only be strong; it must be all-powerful. Modern statesmen are fully alive to this fact, and the present Government (1907), with all its economies, has claimed that the fleet is still in excess of the two-power standard. The world bristles with our fully- and partly-fortified coaling stations. Our commerce is everywhere, and everywhere predominant. Happy shall we be, and happy will the world be, if we are never again called upon to defend that commerce with the infernal and barbarous weapons of modern warfare, for frightful indeed would the struggle be, and slow the recovery from it. 


\section{CHAPTER XI}

\section{HISTORIC TOWNS}

1. The Teaching of Historic Towns.-An important and somewhat neglected aspect of geography which is well recognized, but not often pursued with thoroughness, is the study of towns. This is really the domain of commercial geography in most instances; but we must recognize that the importance of towns is not always a matter of population, though population is, on the whole, the safest guide. Therefore we shall treat of towns which have played a part in history as well as those which play a part in commerce, and, after all, commerce is an aspect of history. We will accordingly classify some of the important towns of the British Isles according to the manner of their growth, and finally take a very few as typical examples. This must not be regarded as in any way an exhaustive list; we only take a few to serve as a guide to the student who is to analyze similar positions.

2. Classification.-It must be said at the start that no one cause will ever account for the existence of any 
one given city. In consequence, some places will appear in more than one class.

The first essential for a group of habitations is water supply. That has never been a difficulty in the British Isles; but some parts of the country are better fitted than others for supporting a large population. Not the least of the assets of the Pennine region is the flattopped gritstone moorlands which hold a great proportion of a pretty heavy rainfall. The Penistone summit of the Great Central Railway, where the line runs beside vast reservoirs miles in aggregate length, gives an excellent object-lesson of the importance of a good supply. When we remember further that these lakes, together with the basins at Audenshaw and Fairfield, are inadequate for Manchester, and that Thirlmere has been tapped for the purpose with a double pipe, that Glasgow is supplied by Loch Katrine, Liverpool by an artificial connection with Lake Vyrnwy, and Birmingham by forming a series of lakes by damming up at intervals the waters of two small rivers on the western border of Radnorshire, in the very heart of the Welsh mountains, involving the construction of an aqueduct 80 miles in length, then we can realize what an urgent question this is.

3. Water supply.-It will be useful, then, to notice how the drainage system of a district has determined sites afterwards to become important. The Aire drainage system emerging on to the lower ground of the 
Vale of York made Leeds possible. "Sheltered valley heads, well supplied with abundant springs of excellent water," 1 are responsible for countless villages all over the country, some of which have grown large from other causes, such as Carmarthen, Belfast, Richmond (Yorks), Selkirk and Appleby. In the Midlands the outcrops of Keuper Sandstone, rich in springs, have proved favourite sites, and Professor Lapworth has said, "All the older towns of the district, Warwick, Coventry, Nuneaton, Tamworth, Bromsgrove, Birmingham, etc.are built upon the outcrops of the Waterstone formation; and the favourite suburbs of these towns lie along its outcrop-Edgbaston, Erdington, Tettenhall, Stourbridge, Leamington. We find upon it also most of the mansions of the older nobility, such as Whitley, Himley, Hagley, Hewell, Warwick, and Edgbaston." On low ground, the presence of impervicus strata, such as clay, beneath gravels or other porous formations, is an incentive to building. Chester is built on sandstone rising above boulder-clay, and so are several villages round. London itself is on "a tract of good gravel, well supplied with water" from the London clay beneath, "not liable to flooding, and not commanded by neighbouring higher ground." 2

4. Confluences of rivers and junctions of roads.-In effect, the junctions of roads and rivers often correspond,

${ }^{1}$ Lord Avebury, Scenery of England, p. 456.

2 Ibid., p. 460. 
as river valleys are always main routes if their heads are conveniently connected with others. All over the world great cities stand at confluences, such as Koblenz (Lahn, Mosel, Rhine), Belgrad (Save, Danube), Lyon (Saône, Rhône), Nizhnii Novgorod (Ọka, Volga), Khartum (Blue Nile, White Nile), St. Louis (Mississippi, Missouri), and hosts of others. In our lands the same thing can be traced with ease. The Cherwell joins the Thames at Oxford and the Kennet runs in at Reading. Dove and Trent join at Burton, Don and Ouse at Goole, Avon and Severn at Tewkesbury, Exe and Culm at Exeter. The reason for this in the case of Britain is partly the frequent occurrence of gravel sheets at such point, making a dry, healthy site, and largely also the ease with which the angle can be fortified. But the joining of routes at these points is the most potent factor in modern times. Where lines of traffic converge, there is the nucleus of a large trading emporium. On the whole, the sites of confluences are not important in our islands; but abroad, where rivers are larger, this consideration is an important one.

5. Tides, river-mouths, harbours.-Tides have always played an important part in navigation, and the highest effective point of the tides up a given river is a likely spot for the founding ' of a village which may grow into a large community. Preston on the Ribble suggests itself. In modern times the exigencies of the position, 
the river being much too shallow and stony for to-day's requirements, have enforced the making of a dock for ocean-going vessels a little lower down the river. Other less important names suggested are Teddington on the Thames, Castleford on the Aire and Tadcaster on the Wharfe. The real instance, however, if we are not sticklers for exactitude, is London.

River-mouths supply numbers of important places, for the obvious reason that one side or the other, or both, of the stream provide convenient harbourage for any number of vessels, provided always there is safety and an adequate depth of water. Instances can be multiplied indefinitely; Dundee, Greenock, Wexford, Waterford, Cork, Dublin, Belfast, Drogheda, Exeter, Plymouth, Hull, Middlesbrough, Boston, and, par excellence, Liverpool. Britain is better supplied in this respect than most countries because our streams are blessed with deep estuaries. The New England coast is a good parallel, and the Nile and Mississippi are good contrasts. Many harbours are to be found away from the mouths of rivers, where the coast structure is favourable. Milford, Pembroke, Falmouth, Sligo, Tralee at home, and Valparaiso, Sydney and Halifax abroad, may be cited. Some of these are at the heads of rivers, but the streams are small enough to be negligible.

6. Fords. - The number of towns situated at fords is very large, and points to both trading and military 
exigencies-passage-ways for transport and vulnerable points to be guarded. A few examples will be selected. Salford, since eclipsed by its younger neighbour Manchester, stands on the Irwell where our ancestors could have crossed. They certainly would not brave the passage now, for the stream has ceased to be the pellucid, babbling flood it once was, and has taken on mourning. Hereford, as has been seen in our chapter on Wales, growing up on the Wye, has played a great part in British history. Oxford was important in Mercian-Wessex days as a border town, there being a passage at the present Folly Bridge, others existing (presumably from early times, though now - dredged) at Medley and Godstow, a short distance farther up. Wallingford was crossed by the Conqueror. ${ }^{1}$ Bishops Stortford, Chelmsford (notable in British and Roman times), Stafford, Bedford, Ashford-there are numbers of them.

7. Modern Developments-Coal and Iron.-No one needs reminding how important are the sites of coalfields. It is these, and the attendant iron-mines and limestone for use as a flux, that have practically created most modern towns of any size. In Scotland, the coal area is dotted with such places as Lanark, Airdrie, Coatbridge, Motherwell, Hamilton and Glasgow. In Cumberland, Maryport, Workington and Whitehaven are well known. In Northumberland and Durham we

1 Chapter V, p. 62. 
are reminded of Newcastle with its attendant ring of towns, with Sunderland, Darlington, Middlesbrough and the Hartlepools near by. Lancashire is a mass of population south of Preston and Colne, and on the other side of the Pennine axis a large manufacturing district extends from north of Leeds through Sheffield to Derby and Nottingham. The Potteries have sprung up on a coal-field. The Black Country between Wolverhampton and Birmingham resembles South Lancashire in its density of population; and South Wales contains Cardiff, Swansea, Merthyr Tydfil, Barry and Newport. Bristol, too, preserves its medieval greatness through the existence of the precious mineral. At the present day, it is true, the introduction of automatic machinery that works with almost uncanny human skill is tending to shift manufactures from the centres of skilled labour to the homes of the raw materials, and the newer industrial centres are competing with the old-established ones; but there is no sign today of any diminution of the output of the vast districts just mentioned, though the wish is father to the thought in the case of our foreign rivals.

8. Towns on great routes. - The chief historical interest attaches to places which stand in conspicuous places on important highways. A very great portion of this work directly bears upon this very subject, so we will deal with it here by way of recapitulation, taking the chief routes in our islands and reminding 
the student of the most interesting points along them.

South-eastwards from London one notes the names of Rochester, Canterbury, and Dover, all of which have played their part in the advances made by Roman, Christian missionary and Norman upon London. This corner of our kingdom has always been most anxiously watched, and the popular feeling against any revival of the Channel Tunnel scheme in $\mathbf{1 9 0 6}$ has shown that history has left its mark upon the mind of England, even in these days of cordial relations with France.

The Brighton and Southampton routes have not yet played a conspicuous part in our history, but the North Downs are lined with forts, now recognized to be useless, in consequence of a scare got up many years ago, the pamphlet then published (The Battle of Dorking) being still remembered by some. The roads from the west, however, supply us with such names as Taunton (the centre of Monmouth's rebellion), Langport (1645), Bristol (1643 and 1645), and Newbury $(1643,1644)$ on the Kennet valley. Following the Thames, we come to Oxford, notable in the wars of Stephen and Charles I, Edgehill on the Cherwell leading to it, and across the Cotswolds lies Gloucester, the key to the South Wales lowland. Continuing along its coast, Chepstow, Llandaff, Swansea, Carmarthen, Tenby, Milford, Penıbroke and St. David's suggest themselves, with Cardigan, Aberystwyth and Harlech on the way to the north. 
The way through the Midland Gate to Chester and beyond is very important. Close to London we notice St. Albans, and farther out Warwick, Shrewsbury, Stoke, Stafford, Bloreheath, Nantwich, Rowton Heath and Chester itself. Along the north Welsh coastal plain we note Rhuddlan, Deganwy, Conway, Bangor and Carnarvon. In Lancashire, on the way to Scotland, Warrington and Preston remind us of Cromwell. Carlisle has memories too long and chequered to be detailed here. Solway Moss is close by, and from Dumfries we come to Langside on our way to Glasgow, or we pass through to Edinburgh along the path that Charles took on his way south to Worcester. The Great North Road, which we take in conclusion, is the most prolific of them all, especially as we near Scotland. Barnet speaks of Warwick's failure to hold London. Naseby is not far from the main route, and Bosworth is related to it. But as we advance northwards battlefields crowd upon us. Towton, Marston Moor, Bramham Moor and Stamford Bridge near York, with Wakefield Green to the south of them; Northallerton, known from the Battle of the Standard; Neville's Cross by historic Durham; Otterburn on the Rede, where Douglas fought Percy; Alnwick and Wooler, with Homildon Hill and Hedgeley Moor close by ; disastrous Flodden, between Till and Tweed; Berwick with its chequered story, overlooked by Halidon Hill; Dunbar, that speaks of the humiliation of Baliol, and the 
triumph of Cromwell; Musselburgh close to Pinkie Cleugh ; Edinburgh, fairest of capitals save Paris only ; Falkirk, where Wallace was ruined and Hawley was beaten in the ' 45 rebellion; Stirling, famous in itself and also because of Bannockburn; Perth, leading to Killiecrankie Pass or to Aberdeen; and Inverness, with fateful Culloden a few miles away. Thus does history march along our great highways.

We will now select a few historic towns and analyze their position, as a guide to the student in similarly treating other localities. This will be done more or less at random.

9. Manchester. - The name Manchester implies a Roman fortress. The military instinct of this people has been proved by the notable way in which roads and railways have converged upon this spot since their time. The primary cause of the existence of Manchester seems to have been the debouching of many pathways from the Eastern Pennines upon the flat ground where Irwell and Mersey meet. Great highways run in every direction from the great centre; Bury Old and Bury New Road; Rochdale Road, leading to 'Todmorden and Halifax; Oldham Road, going through to Huddersfield; Ashton (Old and New) Road, passing over to Barnsley and Doncaster; Hyde Road, traversing Longdendale to Sheffield; Stockport Road, giving access either to Buxton (or Bakewell) and Derby or to Macclesfield and Hanley through the Midland 
Gate to London; Chester Road, passing Northwich on its way; the Eccles roads, which diverge and reach Liverpool or else Wigan for Preston; and finally the highway which passes the coal villages of Walkden and Farnworth and leads to Bolton and Preston vi Chorley or Blackburn, each with its corresponding railway-these are the spokes of the huge wheel wherein lies the thickest population of the British Isles. The nearness of coal and iron makes it possible to support enormous factories; Galloway's boilers, Mather and Platt's steel goods, Armstrong-Whitworth's guns and armour-plates are all produced here, and enormous quantities of machinery by the Westinghouse at Trafford Park and large firms at Bolton and Oldham. The staple trade, as every one knows, is cotton. Manchester distributes the raw material which comes by the Ship Canal or by rail from Liverpool, and manufactures some of it, sending the rest away to be returned in a finished state, warehoused, and sold. Always clever in textile work, the people of Lancashire created the Industrial Revolution by their inventive skill, and made use of Liverpool, as facing America, for the importation of vast quantities of cotton. So great is the traffic that even the Great Northern and the Great Eastern railways, remote as they are, and the Great Western, branching off a branch line at Crewe, strain every nerve, travelling over foreign metals, to get a share in the carrying of goods. Manchester had dealings 
with Cromwell and the Pretender, but its history is mainly modern and industrial. It is off both the Midland and the North-Western main lines to Scotland. It is a goal in itself.

10. Aberdeen.-Aberdeen is one of the oldest towns in Scotland, though the time of its foundation is obscure. The reasons for its existence are pretty plain, and we select it on account of its being due to interesting causes of both a general and a special type. The general considerations are these : it stands, as its name implies, at the mouth of the Dee, commanding the crossing of this river and of the Don also. It stands, too, on the only first-class road between the Rift Valley and Inverness. Routes from the highlands, following the Don and the Dee, converge here, the natural capital of a wooded pastoral country. It absolutely controls the way from both Strathmore and the Carse of Gowrie, and is the sole gateway to the lowland shoulder of Buchan. It is well situated for the considerable fishing trade of the adjacent North Sea, and in former days used to build a good many clipper vessels for war service, being supplied with materials by its hinterland. In these days of steel that industry has died away. The special feature (and many towns, e.g. Burton-on-Trent, with its suitable water, possess such) is to be found in the geology of the district. Aberdeen granite is used in enormous quantities for building, all over the kingdom, and is a particularly 
handsome variety. The polishing industry, which is very important to the town, was revived here in 1818 by Mr. Alexander Macdonald (Macdonald, Field and Co.), and has become the chief source of prosperity.

11. Oxford. - The position of Oxford would seem to promise a very large town, and, indeed, but for accidental circumstances, a considerable city might have grown up on the site. It stands at the confluence of the Thames and the Cherwell where the united stream cuts its way through a long, low ridge, and is consequently shut in and humid. Built on excellent gravel and being the centre of a very beautiful country, it seems to have simultaneously attracted the royal family and a number of scholars from all round. A dispute in Paris drove many foreign students to Oxford, and the selection of the Beaumont fields for the building of a royal residence must have given the place a great vogue. In consequence of frequent and terrible riots between the townsmen and the students, heavy restrictions were laid upon the former by the king, who always favoured the latter, and this has given the university great power. Oxford was the headquarters of Charles I during the first Civil War, being the most convenient and safe place from which to watch London. It is now an important junction on the Great Western Railway, lines from Birmingham and Worcester converging here to pass down the Thames to Paddington, and Oxford would no doubt have taken the place of Swindon 
as engine-making centre but for university opposition. The city stands, then, in an important position as regards the capital, but from accidental causes it has not reaped the benefit (if such it may be deemed) of that position, and depends almost entirely upon the university for its living, having a population of less than 50,000 .

12. Belfast. - At the head of the Lough facing Galloway, and easily reached from the Clyde, stands Belfast. It has been "made" by the linen trade which can nowhere be carried on with such success as in this neighbourhood, owing to the eminent suitability of the spring-water for bleaching purposes. The manufacture owes much to the settlement of Huguenot families, after the revocation of the Edict of Nantes, at Lisburn, higher up the Lagan. Even foreign yarns are sent here to be bleached, and the Irish linen trade has become concentrated upon this spot. The growth of the city attracted other industries, and two immense ship-building firms have their homes there, land being cheap and coal and iron easily obtainable from the Cumberland ports mentioned in paragraph 7. Most of the exporting is not done direct, but vid Glasgow and Liverpool; but, on the other hand, native produce such as cattle, hogs, butter and eggs are sent across in large quantities to Lancashire, where there are many mouths to feed. The Lough has been pretty frequently used by migratory peoples, probably more often than 
we know; it will be remembered that Edward Bruce and William III both landed at Carrickfergus. Access to the heart of Ireland is quite easy. One can pass without difficulty behind the Mourne Mountains to Newry, Dundalk and Drogheda, or across Monaghan to the Shannon and the south-west.

These few instances will suffice to indicate how to analyze the positions of towns. The student is recommended to proceed similarly with places well known to himself, and with such conspicuously interesting sites as those of Edinburgh, Shrewsbury or Dublin. 


\section{CHAPTER XII}

GREATER BRITAIN

1. The Empire not a geographical unity.-It cannot be too emphatically stated that the study of our foreign possessions is not geographical in the true sense, but historical. No scientific geography worth the name can be got out of the Empire as a whole, and the activities of man have paid no heed whatever to the natural regions of the world. To study our possessions as geography is as aimless as to take up the anatomy of the human body and pay attention only to the right little finger, the left hip joint, the kidneys and the Achilles tendon. It has been, and still is in a less degree, the fashion to dodge from Cape Town to the Falkland Islands, from Cyprus to Tasmania, from Guiana to the Channel Islands without any sense of shock, because they are all British. Macassar is nothing; but we must know every corner of Labuan. Crete does not matter; but we must know all about Cyprus. The coffee, cochineal and indigo of Central America are nothing, unless they come from Belize. Michigan is not one of the Great Lakes, and there are no Rockies south of the forty-ninth parallel. No educational result can be obtained by correlating the divers parts of 
the earth on the ground of their being British. The study of our Empire is history; it is not geography.

2. Economic aspects.-There are many ways of viewing imperial questions, and many standpoints to be taken. So much has been written upon this topic that we only propose to touch upon some economic aspects, and then to inquire, by reference to the map of the world, how far our expansion has been upon inevitable lines, and how far fortuitous. Statistics tell us that we own an area of $11,516,821$ square miles, which is as nearly as possible equivalent to that of Africa. The population is estimated at $394,533,581$. In 1800 we owned $1 \frac{1}{2}$ million square miles, in $18504 \frac{1}{2}$ millions. In 1800 we governed 20 million people and in 1850160 millions. As a mere phenomenon this may well be accounted the biggest fact in the world's history-a stupendous expansion. The situation, however, needs analyzing, and we proceed to do so in the only practical way-by means of figures.

The total imports into the United Kingdom work out as follows :-

India and Ceylon . . . . . $£ 40,540,000$

Australia . . . . . . . $\quad$. $26,969,000$

Canada . . . . . . . . $25,696,000$

New Zealind . $\quad . \quad$. $\quad . \quad$. $\quad$. $13,391,000$

Straits Settlements . . . . . $\quad 6,835,000$

South Africa . $\quad$. $\quad$. . . $5,541,000$

Other British Possessions . 8,896,000

Total Imports from British Possessions . $£ 127,868,000$ 
United States

$£ 115,573,000$

France.

$53,073,000$

Germany

$35,800,000$

Holland

$35,481,000$

Russia.

$33,366,000$

Belgium

$27,751,000$

Argentina

$25,034,000$

Other foreign countries, about . . $111,073,000$

Tutal Imports from Foreign countries

$£ 437,151,000$

These are very striking figures indeed, and tend to show how enormously we are dependent upon foreign countries for food and raw materials. We are the best customer of almost every country in the world. This means that it would be a most serious economic strain on any country to go to war with us. Still more calamitous would a great war, whatever the result, be to us. The nced for peace is indeed urgent; but unhappily opinions are profoundly at variance as to how that peace is to be maintained. We have, fortunately, two good guarantees, a non-party continuity of pacific policy, and a wise and benignant King who has won the highest honours as a successful diplomatist.

The figures for exports are equally instructive, but in a rather different way. They show that our possessions are more dependent upon us than upon foreign countries. The question whether patriotism alone causes them to deal with us to this extent is a delicate one; but there is no reason to doubt that merchants all the world over, irrespective of nationality, buy in 
the cheapest market and sell in the dearest. These are the statistics:-

India and Ceylon . . . . . $£ 45,796,000$

Australia . . . . . . . . $\quad$. $19,476,000$

South Africa . . . . . . $17,839,000$

Canada . . . . . . . . $13,767,000$

New Zealand . . . . . . . $\quad$. $6,995,000$

Hong Kong . . . . . . $\quad 3,842,000$

Straits Settlements . . . . 3,284,000

Other British Possessions . . . 11,713,000

Total Exports to British Possessions . $£ 122,712,000$

United States . . . . . $£ 47,282,000$

Germany . . . . . . . $42,742,000$

France . . . . . . . . $23,233,000$

Russia . . . . . . . . . $\quad . \quad 14,884,000$

Belgium . . . . . . . $14,819,000$

Holland . . . . . . . . $\quad$. $14,517,000$

Argentina $. \quad . \quad . \quad . \quad . \quad . \quad 13,384,000$

China . . . . . . . . $13,299,000$

Japan . $\quad . \quad$. $\quad . \quad$. $\quad . \quad 9,797,000$

Other Foreign countries, about 92,028,000

Total Exports to Foreign countries . . $£ 285,985,000$

The empire exports to the empire goods in the proportionate value, compared with foreign lands, of $20: 13$, and imports in the ratio of $20: 10 \cdot 9 .^{1}$

3. Growth.-There can be no question that a country once committed to expansion is bound to go on in sheer self-defence securing all the salient points on

1 Atlas of the World's Commerce. Newnes. 
the way to its distant territories. The brilliant American naval authority Captain Mahan has pointed this out very forcibly in recent years with regard to his own country. "The serious menace to our Pacific coast and our Pacific trade, if so important a position as Hawaii were held by a possible enemy . . . may be assumed to be generally acknowledged." $\mathrm{He}$ points out " the immense disadvantage to us of any maritime enemy having a coaling-station well within twentyfive hundred miles, as this is, of every point of our coastline from Puget Sound to Mexico. Were there many other available, we might find it difficult to exclude from all. There is, however, but the one." Hawaii has since been annexed by the United States. Indeed, as long as there are fleets and armies, this matter must have full attention. Hence it follows that when once we annexed any considerable territory it was absolutely necessary to safeguard it. by commanding the approaches to it.

4. India.-Greatness in India has been thrust upon us. A mere trade quarrel could hardly at the time have been foreseen to lead to the developments that followed. The victory of Plassey put us in possession of Bengal, and from that time onwards we were compelled, as even Warren Hastings, the executioner of Nuncomar and the spoiler of the poor Begums of Oude, proved beyond cavil, to go on in sheer selfdefence. We have annexed Baluchistan and established 
a very fair modus vivendi in Afghanistan. ${ }^{1}$ Quetta and the Kurram Valley were annexed in 1880, suzerainty was declared over Hunza, Gilgit, Nagar and Chitral; a war was fought in Chitral, and the Pamirs were delimited, between 1893 and 1895 ; in 1901 the Northwest Frontier Province was formed, and the recent Tibet expedition was sent in order to secure a predominant influence in that almost inaccessible land. And how are our communications preserved by sea? Gibraltar, Malta and Port Said secure to us the Mediterranean. Aden guards the south end of the Red Sea, and Socotra, the Laccadives and Maldives belong to us. On the way to Hong Kong we hold the Nicobar Islands, Singapore commands the Straits of Malacca, and Labuan in British North Borneo watches the China coast. South-westwards the Indian Ocean is dotted with English stations, such as the Seychelles, the Chagos Archipelago and Mauritius.

5. Australia.-The southern. island continent and New Zealand were acquired by us in a comparatively peaceable manner, though unfortunately the natives failed to understand our beneficent intentions, and suffered in consequence. A great deal of Dutch territory interposes between Singapore and Thursday Island, but the way from South Africa is perfectly clear, as also from Ceylon to Perth and Melbourne.

1 The Anglo-Russian agreement of 1907 has probably secured us on this frontier. 
6. South Africa.-The nucleus of this vast possession is Cape Town, which was seized by Napoleon at the expense of the Dutch, and by us from him because it was a direct French menace to India. The colony grew at the expense of the Boers, and British territory has gone on increasing until it has on all sides touched that of Portugal or Germany. The last and greatest war and the annexation of the Transvaal and Orange Free State are still very fresh in the memory.

Madeira, the Canary Islands and the Cape Verdes are foreign coaling-stations of some importance, but farther south lie Ascension and St. Helena, in our hands, and the western shore of Africa has all its ports of any value, save only that at the mouth of the Congo, in British control, viz., Bathurst, Sierra Leone, Cape Coast Castle, Lagos and Walfisch Bay. But these are all of secondary interest. Egypt, Nubia and British East Africa, the first being a sphere of influence, and not an actual possession, have fallen to us by discovering enterprise and by reason of our joint intervention with France in the internal administration of the lower Nile. Our work, pioneered by Lord Cromer (now retired), has done us immense credit, the Nile barrage being the most notable undertaking. The same route which is secured on the way to India safeguards Egypt, and the recent Anglo-French agreement has given us a free hand in this territory.

7. Canada.-Halifax, St. John's (Newfoundland) and 
Quebec are our chief safeguards of the road to British North America, with Victoria on the west; but on the landward-side Canada is peculiarly vulnerable. It is by far the less rich portion of the continent, but has nevertheless vast resources, and supplies us with great quantities of timber, animals and foodstuffs. Hudson's Bay is too remote to bear relation to any great route, and only possesses two small ports or outposts.

8. Conclusion.-Greater Britain is the outcome of the use, by a peculiarly energetic people, of a favourable geographical position. Our maritime home has rightly been put down as a cause of our pushful, determined nature, and geography has played its part in this great phase of the world's history as in most others. Our sailors have looked to other lands in a spirit of adventure and love of glory; but we did not conquer our present possessions merely from savage motives of aggression. When the great testing-time came, it was evident that we must expand or be absorbed. Nothing short of world-wide conquest could save us from extinction by Louis XIV or Napoleon. William of Orange saw this, and Pitt also, and did not wait to be attacked. There can be no question that an inanimate, defensive England would have been lost. England did not lose; but she is faced instead by responsibilities such as have weighed upon no other nation upon earth. And who, we ask, could have borne them so well? India alone has presented problems which staggered 
mankind till we set foot there. England has given India as much personal liberty as India can bear, and has struck that happy mean between tyranny and democracy which would have appealed to no other dominant country, and which alone could succeed. The Anglo-Saxon is not beloved there, but he rules, and rules beneficently. And so, viewing our past history, we look back with pardonable pride, and regard the future with assurance of success, and a radiant hope. 


\section{INDEX}

Aberdeen, 31, 89, 135, 166 Aberystwyth, 36, 75, 83, 162 Aden, 5, 175

Afghanistan, 6, 10, 174

Aire R., 34, 111

Albania, 6

Alfred the Great, 61,127

Alnwick, 65, 88, 91, 92, 97, 163

Alps, 5

Altai Mts., 17

Amazon R., 4, 23

Anglesey, 75, 77, 81, 84, 130

Antrim, 43

Archæan rocks, 9, 29

Asia Minor, 20

Atacama, 20

Athenians, 7

Ayr, 94, 136

Bagdad, 4

Bannockburn, 95, 116, 164

Barnet, 55, 65

Barrow, 34, 43

Beaulien, 50

Belfast, 43, 157, 159, 168

Belgrad, 158

Beluchistan, 174

Berwick, 32, 34, 92, 93, 101, 108, 134,136

Bidarras, 27

Birmingham, 38, 156, 157, 161

Blaskets, The, 48119

Bohemia, 73

Bolton, 165
Bosworth, 65

Boulogne, 7, 52

Boyne R., 45, 122

Bradford, 35

Brest, 52, 53

Brighton, 41, 146, 162

Bristol, 36, 43, 86, 134, 161, 162

Brythons, 46

Burnley, 164

Bury, 164

Cadiz, 47

Caithness, 31, 89, 90, 104

Cambridge, 40

Canterbury, 55, 60, 62, 162

Cape Town, 17

Caratacus, 76, 77

Cardiff, 36

Carlisle, 32, 34, 71, 88, 94, 109

Carmarthen, 36, 77, 131, 157

Carnarvon, 77, 130, 131

Carstairs, 33

Caspian Sea, 19

Castle Cary, 36

Caştle Douglas, 33

Chester, 37, 61, 82, 128, 130, 134, 157,163

Cheviot Hills, 88

Chiltern Hills, 39, 62

Clyde R., 4, 43, 92, 100, 136

Colchester, 54, 60, 128

Congo R., 23

Conway, 75, 78, 80, 87, 131

Cork, 43,44 
Cotentin Peninsula, 49

Cotswold Hills, 35, 39, 71

Crewe, 34

Cromwell, Oliver, $3,101,104,121$, 148,166

Culloden, 31, 110

Dartmoor, 36

Dee R., 79

Deganwy, 75, 78

Deheubarth, 83

Denbigh, 131

Derby, 38, 70, 128, 161

Doncaster, 34

Dorking, 41, 162

Dorset, Origin of, 126

Dover, 42, 51, 60, 61, 62, 143, 148, 149,162

Dublin, 3, 43, 44, 113, 115, 116, 117,159

Dumfries, 33, 71, 94

Dumbar, 32, 34, 89, 100, 105, 108, 163

Dundee, 102

Dunstable, 39

Durham, 34, 88, 129, 163

Dynevor, 81,130

Dyved, 76,80

Ebbsfleet, 54

Edgehill, 66

Edinburgh, 31, 32, 34, 99, 100, $103,105,108,133,163,164$

Edward I, 83, 92, 135

Elgin, 103

Essex, Origin of, 125

Evolution, 12

Exeter, 36, 50, 158

Exmoor, 36

Falkirk, 89, 93, 109, 164

Fife, 105, 135

Fishguard, 36, 43, 117

Flint, 131

Flodden, 98, 99

Fort William, 30, 31, 102

Forth R., 32, 53, 90, 105
Galloway, 90, 134, 136

Geikie, Sir A., 8, 47, 95

Ghegs, 6

Gibraltar, 152, 153, 154, 175

Ginkel, General, 122

Glasgow, 4, 31, 33, 101, 103, 107, 160,163

Glen Coe, 30, 107

Glen More, 31, 91

Gloucester, 37, 78, 79, 80, 128, 130,162

Goidels, 45

Grantham, 31

Gravelines, 48

Greenland, $14(1 b)$

Guadalquivir, 148

Guildford, 41, 60

Gwent, 76

Halifax (Nova Scotia), 176

Hannibal, 5

Hartlepool, 161

Herbertson, A. J., 13

Hereford, 71, 75, 78, 128, 160

Hexham, 34, 97

Hudson's Bay, 4, 177

Humber, 37, 53

Iberians, 46

India, 174, 177

Inverness, $31,89,103,106,109$, 110,135

Iran, 20

Irwell R., 160, 164

Itchen R., 51

Kamchatka, 14

Kent, 26, 41, 42, 63

Khartum, 158

Killiecrankie, 31, 106, 164

Kinder Scout, 35

Korean Straits, 8

Lahn R., 136

La Hogue, 151

Lancashire, 6, 35, 130

Lancaster, 34,88 
Largs, 92

Leeds, 34, 35, 161

Leicester, 38, 127

Liffey R., 45

Limerick, 44, 120, 121, 122

Lisbon, 3

Liverpool, 1, 36, 156, 159, 165

Lomond, Loch, 30

Long, Loch, 30

Lowestoft, 150

Lyme Regis, 50

Lyon, 158

Mackinder, H. J., 51, 60, 129

Malta, 175

Mallaig, 30

Manchester, 36, 109, 128, 156, 160,164

Mediterranean Sea, 17

Mersey, 43, 128, 164

Midland Gate, 2, 45, 75, 129

Môn, 75, 77, 81, 84, 130

Monmouth, D. of, 5056

Montgomery, 75, 80, 83, 131

Morgannwg, 76

Napoleon, 3, 7, 52, 140, 153, 175, 177.

Newcastle-on-Tyne, 34, 96, 163

Nile R., 176

Nizhnii Novgorod, 158

Northallerton, 34, 88, 92, 163

Norway, 27, 28, 52

Nottingham, 38

Oban, 30,31

Oka R., 158

Oldham, 164

Orkney Is., 29, 48, 90, 92

Ouse, Great, 39

Ouse, Yorkshire, 35

Oxford, 37, 40, 60, 66, 67, 68, $128,158,160,162,167$

Peak, The, 35

Pembroke, 75, 80, 86, 159, 162

Pennines, 38
Perth, 31, 95, 96, 103, 107, 108, 135

Philiphaugh, 104

Pinkie, 100, 46

Plymouth, 36

Powys, 76, 130

l'reston, 34, 80, 89, 104, 109, 158,163

Quebec, 16, 176

Quetta, 174

Quiberon Bay, 152

Ravenspur, 55, 65, 117

Reading, 158

Redhill, 42

Reigate, 42

Rhine R., 28, 53, 69

Rhone R., 5

Rhuddlan, 80, 81, 84

Rochdale, 164

Rosslare, 43, 117

Sahara, 20, 21

Salford, 160

Salisbury, 36

Sandwich, 52, 141

Schimper, A. F. W., 23

Sedgemoor, 50

Senlac, 52

Severn R., 35, 39

Shar Range, 6

Shannon R., 116, 169

Sheffield, 34, 35, 129, 161

Shetland Is., 29, 90, 92

Shrewsbury, 37, 63, 66, 75, 77,

$78,79,83,85,87,128,130,163$

Skerryvore, 47

Sligo, 49

Sluys, 144, 145

Smerwick, 119

Snowdon, $36,80,82,130$

Somerset, 37

Southampton, 51, 162

Steppes, 17

Stirling, 32, 103, 105, 107, 109, $134,135,164$ 
Strathclyde, 90, 134

Strathmore, 32, 90, 106

Strome Ferry, 30

Stockport, 164

Sunderland, 34, 161

Surrey, 41, 126, 132

Sussex, 126, 132

Taunton, 50

Tay R., 32, 53

Tehuktchis, 26

Tees R., 38, 90

Tewkesbury, 49, 56, 65

Texel, 149, 151

Thames R., 39, 47, 158

Timbuktu, 4

Tippermuir, 102

Tor Bay, 50, 151

Toulon, 52

Toskhs, 6

Towton, 05

Trans-Siberian Railway, 8

Turan, 19

Turin, 5
Tweed R., 95, 98, 104

Tyne R., 34, 96, 97, $10 \mathrm{I}$

Volga R., 158

Wallace, William, 93

Wallingford, 62, 63, 160

Warbeck, 28, 50, 56

Warrington, 34, 104, 163

Waterford, 115, 116, 117, 159

Weald, The, 40

Welsh character, 73

Wexford, 43, 115, 116, 159

Weymouth, 49

Whitesand Bay, 50

William I, 52, 62, 79, 91, 143

Winchester, 62, 63

Worcester, 38, 60, 68, 78, 128, 163

Wye R., 75, 80, 160

Ynys Enlli, 130

York, 34, 59, 65, 67, 95, 129

York, Vale of, $33,38,63,134$

Yorkshire, 7 


\section{Dent's New Series of \\ Mathematical and Scientific Text Books for Schools}

Enited by W. J. GREENSTREET, M.A., F.R.A.S.

Headmaster of the Marling School, Stroud, Glos. Editor of "The Mathematical Gazette."

\section{NOW READY. \\ PRACTICAL NATURE STUDY FOR SCHOOLS \\ By OSWALD H. LATTER, M.A.}

Senior Science Master at Charterhouse, formerly Tutor of Keble College, Oxford.

Part I (Pupil's Book), 2s. 6d. net.

Part II. (Teacher's Aid and Answers), 6s. net.

Part II is supplied to recognized Teachers only.

The School Guardian says: "We heartily commend this book to all teachers who include Nature study in their time-tables."

The School World says: "It is impossible to speak too highly of the skill with which the questions have been framed."

\section{A FIRST BOOK OF GEOMETRY \\ BY W. H. YOUNG, D.Sc. \\ Scnior Examiner to the Welsh Examination Board \\ AND \\ Mrs. YOUNG, Ph.D.}

Cr. 8vo. 1s. $6 d$. net.

With Three Cololred and Many Other Illustrative Diagrans.

The' Sihool World says: "We have read the book with unusual interest. IVe cordially recommend this book to the attention of teachers and parents."

\section{PRACTICAL PHYSICS.}

$$
\text { By F. J. Tristram, M.A. F'cap. 8vo, } 1 \text { s. 6 } d \text {. }
$$

Education says: "This admirable little book approaches very near to our ideal of an elementary text-book of Practical Physics. . . . Fortunate indeed is the student who has his powers of observation and manipulative skill trained on the lines indicated in this excellent little book." 
LIGHT. By F. E. Rees, B.Sc., late Demonstrator of Physics, Bangor. Cr. 8vo, 2s.

The Schoolmaster says: "Exceedngly well done. Displays knowledge and thoughtful care on every page."

A FIRST STATICS. By C. S. J J structor in Mathematics at the Royal Military Academy, Woolwich ; and R. M. MiLne, Assistant Master, Royal Naval College, Dartmouth. Cr. 8vo. With or without Answers, 4s. 6d.

TRIGONOMETRY. By Cecil Hawrins, M.A., Haileybury College, Hertford. Member of Mathematical Association Committee on the Teaching of Mathematics. Without Answers, 3s. 6d. ; with 4s.

GEOMETRICAL CONICS. By Prof. G. H. BRYAN, F.R.S., and Prof. R. H. Pinkerton, M.A. 3s. $6 d$.

PRACTICAL BOTANY. By E. H. Davies, B.Sc. 2s.

GERMAN SCIENCE READER. Compiled by C. R. Dow, M.Sc. Part 1.-Mathematics, Physics and Chemistry. Sm. Cr. 8vo, 2s.

ANALYTICAL CONICS. By Prof. Miss C. A. Scotr, D.Sc., Brynnawr University, U.S.A. 3s. $6 d$.

The following Books are in preparation

ALGEBRA. By Prof. H. W. L.. Tanner, F.R.S., and W. J. Greenstreet, M.A., F.R.A.S.

PRACTICAL MATHEMATICS. By J. E. Boyt, B.A., B.Sc., Headmaster of King Edward VI Grammar School, Stowbridge.

FRENCH SCIENCE READER. Compiled by W. J. Greenstreet, M.A.

MATHEMATICAL TABLES. By Prof. G. H. BRYAN, F.R.S.

WITH OTHERS TO FOLLOW

London: J. M. DENT \& Co., 29 Bedford Street, W.C. 

D

209

D35

v.1
Dann, Ernest Walter

Historical geography on a regional basis
PLEASE DO NOT REMOVE

CARDS OR SLIPS FROM THIS POCKET

UNIVERSITY OF TORONTO LIBRARY 

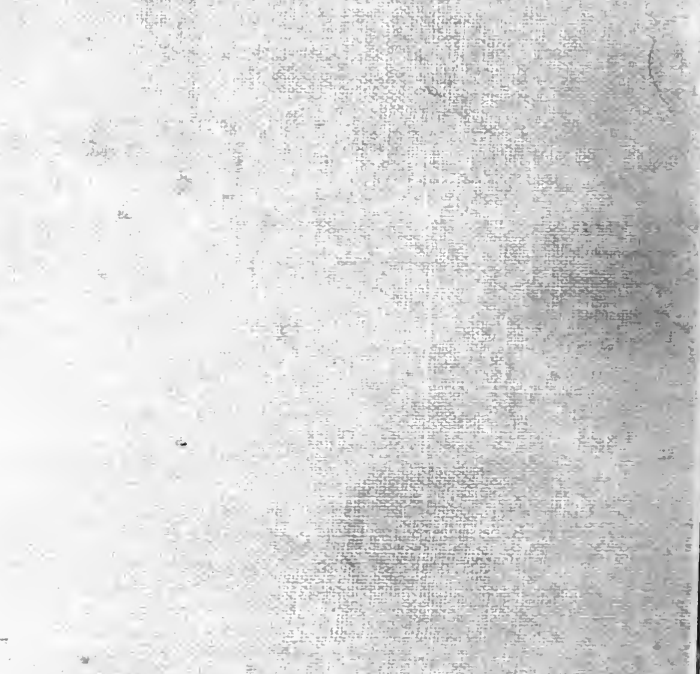

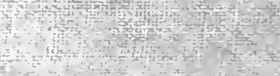

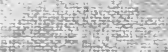

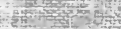

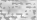

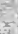

(it) (1)

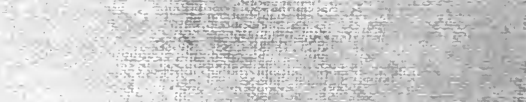

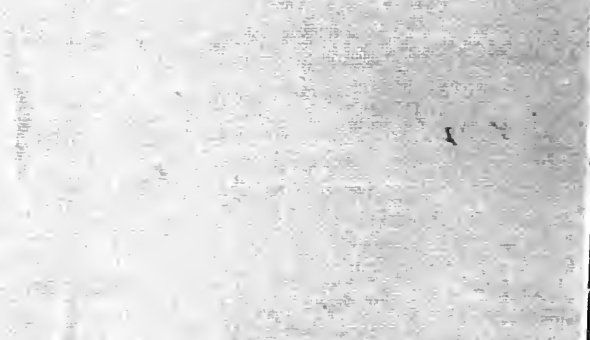

